A 42 



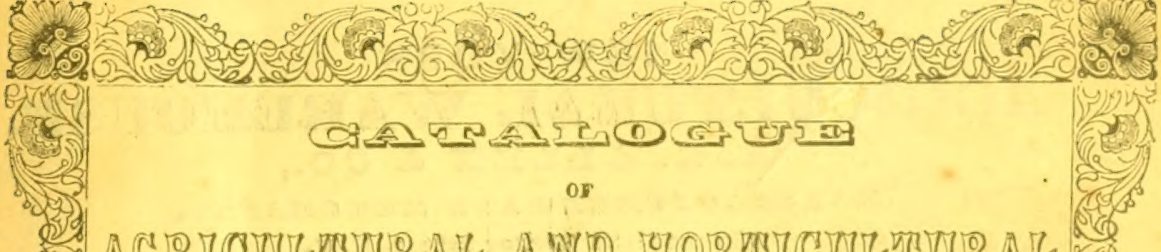

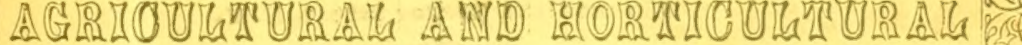

\%

sac

(rite

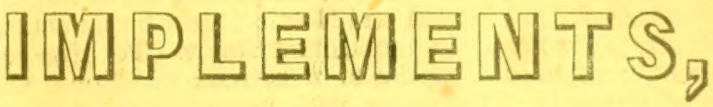

AND OF

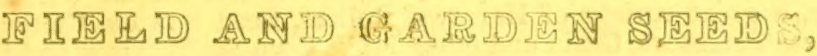

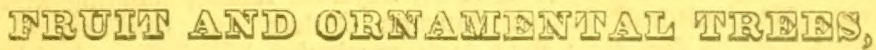

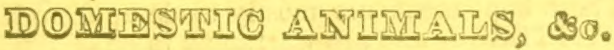

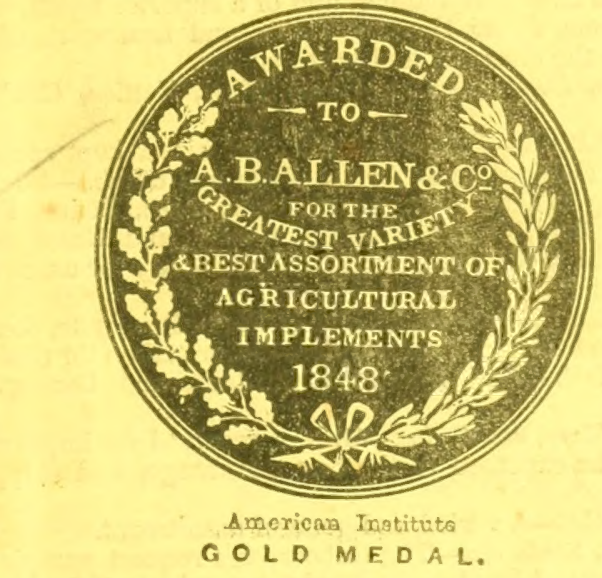

Americar Institute

GOLD MEDAL.

THIRTEENTH EDITICIN.

bus

(exte

गै

(1)

Ny 


\section{NEW-VORK

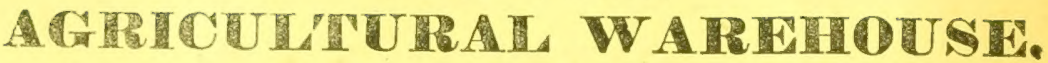 A. B. AILEN \& CO.,

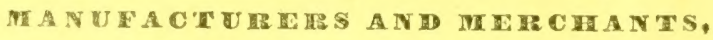 189 and 191 Water Street, T. X.}

WE respectfully invite the attention of the public, to the largest and most complete assortment of Agricultural and Horticultural Implements, and Field and Garden Seeds, to be found in the United States. 'To give some idea of our establishment, and to save replies to numerous questions, we have issued a Catalogue of upwards of 100 pages, with numerous engravings, descriptive of the above, which will be distributed gratis, on application for it, post paid.

The Implements embrace upwards of ONE HUNDRED different kinds of Plows, a great variety of Harrows, Rollers, Seed Sowers, Cultivators, Horse Powers, Threshers, Grain and other Mills, Corn-Stalk, Straw and Hay Cutters, Corn Shellers, Shovels, Spades, Hoes, Scythes, Rakes, Budding and Grafting Knives; Horticultural Tools; Sausage Cutters and Stuffers; also, Carts, Wagons, Trucks, \&c., \&c.; for a more particular description of which. see the Catalogue. These implements are mostly made up from NEW and HIGHLYMMPROVED PATTERNS, and are warranted to be of the best materials, and put together in the strongest manner, and of a superior finish.

Castings, Skeleton Plows, Harrow Teeth, and iron work of all linds furnished to order in the cheapest and best manner.

Sleam Engines, Sugar Boilers, Sugar Mills, Kettles, Cauldrons, \&c., for plantations.

Wire Cloth and Sieves-Different kinds and sizes, kept constantly on hand.

American and Foreign Seeds for the Field and Garden-Such as Improved Winter and Spring Wheat, Rye, Barley, Oats, Corn, Beans, Peas, Rutabaga, Turnip, Cabbage, Beet, Carrot, Parsnip, Clover and Grass seeds, approved varieties of Potatoes, \&c. These are grown expressly for us, and are fresh and superior of their kind.

Fertilisers.-Guano, Bonedust, Plaster of Paris, Poudrette, \&c.

Fruit and Ornamental Trees and Shrubs.-Orders taken for these, and executed from a choice of the best Nurseries, Gardens, and Conservatories in the United States.

Horses, Callte, Sheep, and Swine-Orders received for improved stock of all kinds, which will be executed to the best advantage, and shipped in the most careful manner.

Agricullural Books.-A varied and general assortment.

New Implements, Seeds, \&c.-The Subscribers request samples sent to them of any new or improved Implement, Seeds, \&c., which, if found valuable, extra pains will be taken to bring them before the public.

Produce on Consignment.-All kinds of Agricultural Produce will be received for sale on consignment.

A. B. ALLEN \& CO., 189 and 191 Water street, New York.

\section{A U T ION.}

As certain houses in this city are in the habit of selling Agricultural and Horticultural Implements, and Field and Garden Seeds, representing them as coming from our establishment, the public is cautioned to be on its guard against imposition. All implements and parcels sold by us, which it is possible to mark, will be found branded

\section{"A. B. AIIEN \& CO., 189 and 191 Water St., N. Y."}

When designing to call at our warehouse, please to be careful and look for the right numbers as above, otherwise impositions may be practised on the unwary. 


\section{TAKE PARTICULAR NOTICE!!}

All orders for goods, \&c., must be addressed us, post-paid, and accompanied with the money, or a draft at sight, or acceptance, on some responsible house in this city, Boston, Philadelphia, or Baltimore.

The direction for the goods must be written out in full, in a clear, legible hand, otherwise mistakes and delays are liable to occur.

Insurance will be effected at the lowest rates whenever desired.

Any other kind of goods wanted for the farm, plantation, house, or family use, will be purchased on the best terms, as we are conversant with most kinds of merchandise, and have facilities for executing orders not surpassed by any house in this city.

\section{PRODUCE ON CONSIGNMENT.}

We are prepared to receive all kinds of Agricultural Produce for sale on commission; such as grain, seeds, beef, pork, lard, cotton, sugar, rice, tobaceo, hemp, wool, \&c., \&c.

A. B. ALLEN \& CO. 


\title{
AMERICAN AGRICULTURIST,
}

\section{A MONTELY PERTODICAL,}

Designed to improve the Farmer, the Planter, the Stock-Breeder, and the Horticulturlst.

\author{
A. B. \& R. L. ALLEN, EDITORs.
}

Agrieulture is the most healthy, the most uscful, and the must noble employment of man.

WAS BINGTON.

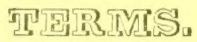

ONE DOELARE A TEAT IN ATVANCE.

Three Copies One Year, or one Copy Three Years, \$2.

\section{Published by C. M. SAXTON, 152 Fulton st., N. Y.}

THE AMERICAN AGRICULTURIST is now in the ninth year of its publication. From its commencement, it took a high stand, and has ever since been considered by the press and all unbiased judges, as the LEADING PERIODICAL of its class in America. It has a large and rapidly-increasing circulation throughout the United States, the Canadas, and other British Possessions, the West Indies, and South America ; and we may fearlessly assert, that it has given more reliable information on rural subjects, and has been perused with greater general satisfaction, than any paper of the kind yet published.

The Agriculturist treats of every description of domestic animal and poultry ; their mode of breeding, feeding, and rearing; their uses, profits, and management. It treats of the various cultivated crops, including fruits, shrubbery, and flowers; the best seeds, modes of planting, cultivating, gathering, and preparing for market; the general principles of vegetation, and the laws of vegetable life.

It describes the principles of mechanics as applied to machinery employed by farmers and planters; the best machines and implements for agriculture, their uses, and the particular superiority of some over others, and their adaptedness for particular purposes. It gives the latest improvements in those implements which may have been made, and suggests others; tells where they are to be found, and the benefits that will follow from their use. It specifies new objects of cultivation, and how they may be better prepared for a profitable market and a more general use.

This is the great design and scope of the Agriculturist; and these are the paramount objects of interest throughout America. No country can ever enjoy solid prosperity unless an enlightened system of agriculture is practised among its people, and this cannot be done except by the aid of works which are written to teach it. Let all aid, then, to spread them broadcast throughout the land. It is the duty of every good citizen to do this-nothing equal to it can be done to benefit the country. 


\title{
ALMACEN DE AGRICULTURA,
}

\author{
ESTABLECIDO EN LA CIUDAD DE NEW YORK \\ Por los Seinores A. B. ALLEN y COMPAŃIA, \\ CaLle de Water, No. 191.
}

LUS que suscriben habiendo desde mucho tiempo conocido la necesidad que habia en esta ciudad de un establecimiento, donde pudiera encontrarse un surtido de in strumentos de agricultura, semillas, plantas, arboles y abonos, mas escojido y variado de lo que existia en New York, abriéron el año de 1845 un almácen en la calle de Water, para la venta de todo lo perteneciente al ramo de agricultura. Ellos tienen el surtido mas abundante y completo que hay en los Estados Unidos, y convidan á todos para que vengan y examinen personalmente. Para dar alguna idea de su establecimiento y evitar la necesidad de responder á muchas preguntas publican este catálogo, que se distribuirá gralis á las personas que deseen tenerlo. Todo comunicado remitido con el objeto de pedir el catálogo debe ser franco de porte.

El surtido de instrumentos abraza mas de ciento elases diferentes de arados, una gran variedad de gradas, cultivadores (cultivators), rodillos, sembradores, potencias motrices para caballos; máquinas de trillar, para moler y para cortar los tallos del maiz (maloja) paja y heno; desgranadores, palas, legones, azadas, guadanas, rastros, cuchillos, \&c., \&c., de todo lo eual se encontrará una descripcion mas circumstanciada en el catálogo que se acompaña. Casi todos estos instrumentos estan hechos por modelos uuevos y muy mejorados y se garantiza que los materiales son de los mejores y la obra muy fuerte y superior.

Se hacen toda obra de fundicion, arados de armazon (skeleton-plows), dientes de gradas y obra de fierro de todas especies por los precios mas equitativos y del mejor modo, segun las órdenes que se reciban.

Máquinas de vapor, refinadores de azucar, trapiches, pailas, calderas, \&c., para los injenios.

Tela de alambre y cedazos.-Se encuentran constantemente de diferentes calidades y tamaños.

Semillas para el campo y las huertas-Por ejemplo, trigo de invierno y primavera de superior calidad, centeno, cebada, avena, maiz, habas, arbejas (guisantes), nabos, rutabaga, coles, remolacha, zanahoria, chirivia, semilla de trebol y otras yeroas, varias clases de papas de superior calidad, \&c., \&c. Se garantiza que las semilla son frescas, y de superior calidad.

Abonos.-Gnano del Perú y tambien Africano, cal, yeso, \&c., \&c.

Arboles y arbustos frutales y de adorno.- Todos los pedidos que vengan de estos articulos seran atendidos con puntualidad y se escojeran los arboles y arbustos de las mejores huertas y planteles de los Eslados Unidos.

Caballos, ganado vacuno, carneros y cerdos.-Todas las órdenes que se reciban para remitir animales de todas especies seran ejecutadas con todo esmero, y se efectuará el embarque con mucho cuidado.

Libros de agricultura.-Hav de venta un surtido general y abundante de estos.

Nuevos instrumentos, semillas, $₫ \cdot c$.--Los que subseriben tendran mucho gusto, te recibir muestras de todos instrumentos nuevos y mejorados, de semilias, \&c., y haran todo lo posible de su parte para darios á conocer al público, si en su opinion lo merecen.

Frutos en consignacion.-Se recibirâ toda especie de frutos para vencler en con. signacion.

Enero, 1851.

A. B. ALLEN y Ca., New York, calle de Water, No. 191.

\section{The American Agriculturist.}

(EL AGRICULTOR AMERICANO.)

Esta obra consiste de treinta $y$ dos pajinas de octavo, $y$ tiene muchas $y$ hermosas làminas. Su objeto es instruir al labrador, hacendado, criador de animales y al ja: dinero. Su eủitor es el Señor A. B. Alolen, y la publican el ceñor Chartes M. S A X Tun, de New York. El precio de la suscripcion es un peso fuerte por año. E! decimo volúmen principio el $1^{\circledR}$ de Enero de 1851. Se venden lus volumenes anteriores encuadernados con elegancia y uniformidad por el precio di $\$ 1.25 \%$ 


\title{
Entrepôt d'Instrumens aratoires,
}

\author{
A NEW YORK, FONDÊ EN 1845,
}

\author{
PAR MESSR, A. B, ALLEN et Cie.,
}

\author{
191 W A TER STREET, NEW YORK.
}

I.es fermiers, planteurs et horticulteurs trouveront l'assortiment le plus com plet d'instrumens aratoires, perfectionnés, de tous genres, qui ait jamais été of fert en vente à New York, en s'adressant à l'établissement ci-dessus men. tionné. La plupart de ces instrumens sont fabriqués d'après les plus nouveaux modèles et les perfectionnemens les plus récens; ils sont construits avec beaucoup de solidité et des meilleurs matériaux, et seront vendus aux prix les plus modérés, au comptant.

Au nombre de ces instrumens, on trouvera plus de CENT différentes es. pèces de charrues, sortant des manufactures de New York et de celles de Rug. gles, Nourse et Mason, de Worcester, état du Massachusetts, et qui sont adaptées à l'usage du Sud aussi bien qu'à celui du Nord; des herses de grandeurs et de formes différentes ; des rouleaux en bois et en fonte, fabriqués d'après un nouveau procédé ; des semoirs d'un nouveau genre pour toute espèce de graines; sultivateurs, avec diverses espèces de dents; machines pour économiser le travail à chevaux (horse-powers), soit en bois ou en fer de fonte, très solides et d'une qualité supérieure; instrumens pour battre le grain; vans; moulins à moudre le maïs, de nouvelle invention; égrenoirs, soit à la main, soit par des chevaux, ceux-ci pouvant égrener 200 boisseaux d'épis de maïs par heure; coupe-légumes, pouvant couper un boisseau de racines pour bestiaux en deux minutes; hache-pailles, faux, râteaux, bêches, pelles, houes; en un mot, des instrumens aratoires de toutes sortes pour les travaux des champs et du jardinage.

Moulures pour les différentes espèces de charrues fabriquées à New York.

Graines de fermage et de jardinage.-Un assortiment choisi de toutes les variétés, telles que le blé d'hiver et de printemps, 1re qualité, seigle, orge, avoine, maïs, fèves, pois, navets, rutabaga, choux, betteraves, panais, trèfle, graines de gazon, et diverses espèces perfectionnées de pommes de terre.

Tamis et toile de fil de fer de différentes espèces et constamment en magasin

Engrais.-Guano du Pérou et de l'Afrique, cendres d'os, chaux, plâtre de Paris, etc.

Arbres fruitiers, arbustes, etc.-Des commandes pour cette partie seront exécutées en faisant un choix dans les meilleures pépinières, serres-chaudes, etc., des Etats-Unis.

Chevaux, bestiaux, moutons, cochons.--Des commandes seront fidèlement executées en vue de l'avantage de l'acquéreur.

Un catalogue descriptif, de 100 pages, avec gravures sur bois, sera envoyé gratis, en s'adressant franc de port aux soussignés

Janver, 1851.

\section{The American Agriculturist,}

\section{REVUE MENSUElle DE 32 Pages}

In-8vo, ornée de nombreuses gravures.-Prix d’abonnement, \$1 par an.

On fera une déduction à ceux qui achètent pour revendre.

A. B. ALLEN et Cie.

No. 191 Water street, New York. 


\title{
$\operatorname{Xes}=9 \mathfrak{D} \mathfrak{x}$ Agricultur - Waaren - fager
}

bon

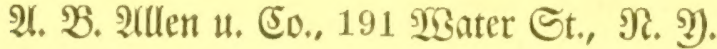

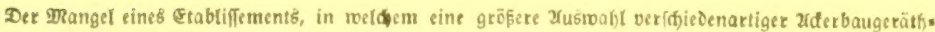
fWaften und mannigfaltiger Getreidearten, Eämercien, \$fanyen, von Bäumen unD Düngungemateriat, al\& bistber in irgend einem gocale begogen werden tann, ift felfr aflgemein empfunden; um Diefem Bedürfs

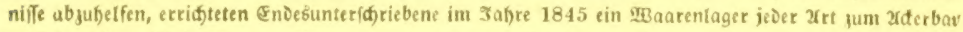

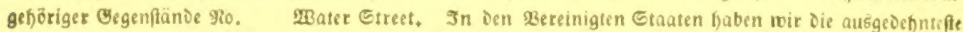

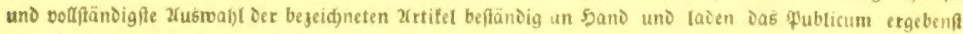

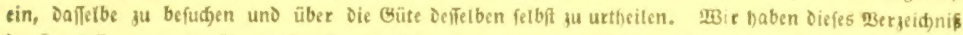

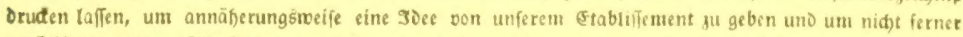
genöthigt ju fein, auf Znfragen zu antworten; Daffelbe wiro auf Serlangen einem Seden une n tgelo= (i d) jugefteft weroen. Desfalfige Mittheilungen find jedod portofrei einaufenden.

Die (5exät b) eine grofe :Mannigfaltigteit bon Eggen, "Sultivators" "Rollen, Eaemafdinen, Majdjinen bon ein= uno

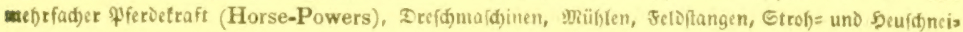

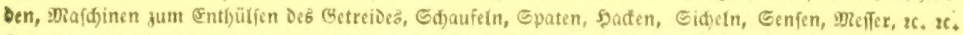

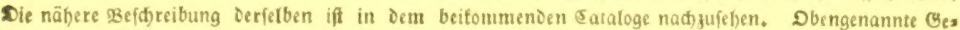

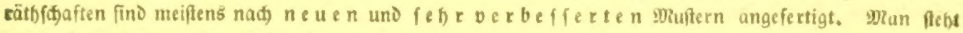

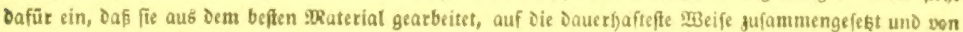
corjügtidfem $2(n$ (n)

«u sen weroch auf Beffellung aufb Befle und Biffigfte angefertigt.

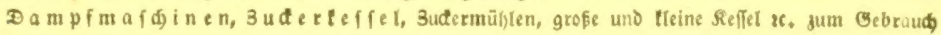
auf Den $\$$ lantagen.

Deathreet un D E iebe - von verífiedener att und Grōße, find immer vorräthig.

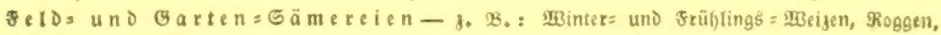

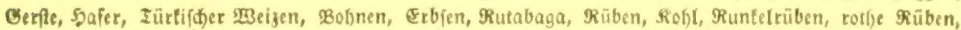
Paftinaden, Rlee= und Grubs: Saamen, Deredete Rartofeín veridjiedener $2\left(r t, x_{*} x\right.$. Man ftef)t Dafür ein, bas fie frif() uno yon vorzügliḑer Güte fino.

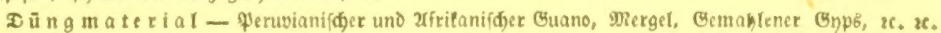

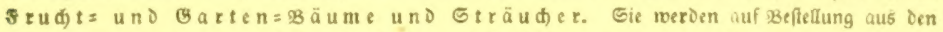

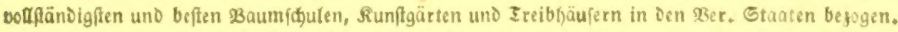

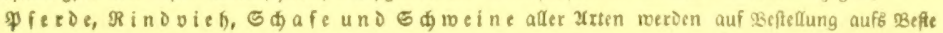
bejorgt uno mit größter Eorgfalt verídifft.

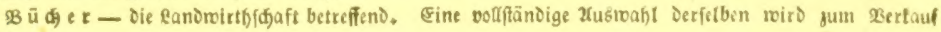
aubgeboten.

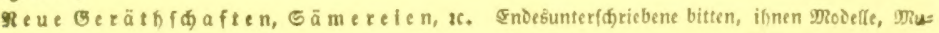
Rer und \$roben von irgend neuen verbefferten Gerätlf(d)aften, Eämereien as ju३ufenden; weenn fie für

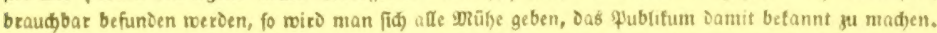

Getreide auf 5.onfignation - zafe arten von Gstreide weroen sum Berfauf auf Eonfignas tion entgegengenommen.

ฐanuar, 1851 .

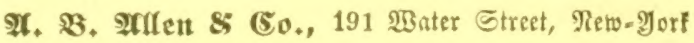

"The American Agriculturist"- Ein monattiches glatt von moei uno oreifig Eciten Detavo, mit

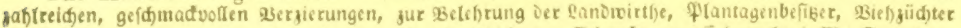

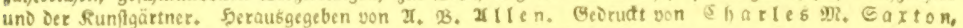

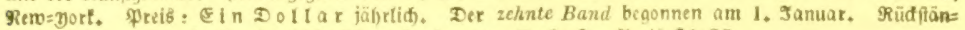

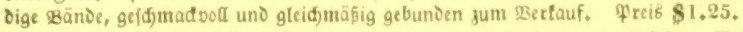

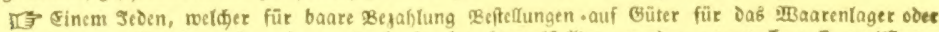
Gubicriptionen für oen American Agriculturist bewertfetfigt, weroen angemeffene Eommifionem gegeben. 


\section{PRICE S}

OF

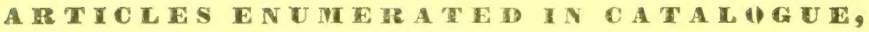
MANUFACTURED OR FOR SALE BY

\section{A. B. $A L L \mathbb{N} \&$ C O.,}

189 AND 191 WATSIR STREET, N. Y.

Boilers, Vegetable, (Mott's,) 15 gallons, $\$ 9 ; 22$ gallons, $\$ 12 ; 30$ gallons, $\$ 15 ; 45$ gallons, $\$ 20$; 60 gallons, $\$ 23 ; 80$ gallons, $\$ 35 ; 120$ gallons, $\$ 50$.

Bee-Hives, Townley's, \$4, Miner'\$ \$5.50

Bush Hook, $\$ 1.12 \frac{1}{2}$, handled, $\$ 1.50$.

Bull-Rings, 75 cents to $\$ 1$.

Brick-Machines, $\$ 125$ to $\$ 300$.

Bark-Mills, $\$ 14$ to $\$ 25$.

Bill or Brier-Hooks, $\$ 1$ to 1.25.

Barrow, Garden, $\$ 4.50$ to $\$ 5$.

Barrow, Railroad, $\$ 2.25$ to $\$ 2.50$.

Bog-Hoe, $\$ 1, \$ 1.25$, and $\$ 1.50$.

Bonedush, ground, 50 cents per bushel.

Carts, mule and ox, $\$ 30$ to $\$ 60$.

Cotton-Gins, $\$ 3$ to $\$ 4$ per saw.

Cultivators, $\$ 4$ to $\$ 5$; do. Universal, $\$ 10$; steel-toothed, $\$ 6$, with wheel, $\$ 6.50$; Langdon's, $\$ 6$ to $\$ 7$; Do. Hand, $\$ 3$.

Cotton-Sweeps, $\$ 10$.

Com-Planter, \$14.

Cradles, grain, $\$ 2$ to $\$ 4$; Scythes, $\$ 1$ extra.

Corn-Shellers, Clinton's Box Sheller, single-wheeled, $\$ 6.50$; do, double-wheeled, $\$ 7$; do. Ironframed, $\$ 9$; Waring's, $\$ 7$ to $\$ 8$; Lewis', with Separator, $\$ 16$; Southern do. for horse or hand power, $\$ 30$; Smith's do. for horse power, $\$ 50$ \& 80 .

Com and Cob-Crushers, $\$ 30$ to $\$ 100$.

Corn and Coffee-Mills, $\$ 1.50$ to $\$ 10$; for hand or horse, $\$ 20$ to $\$ 30$.

Cattle-ties, 38 to 50 cents each.

Churn, Thermometer, No. 0 , for one or two cows, $\$ 3$; for three to îve cows, No. $1, \$ 3.50$; for five to eight cows, No. $2, \$ 4$; larger sizes, from $\$ 4.50$ to $\$ 10$. 


\section{LIST OF PRICES.}

Churns, Kendall'e, for one or two cows, \$2; for three to thre cows, $\$ 2.54$ to 53 : for tive to entitit cows, $\$ 3$; for eight to fifteen cows, $\$ 3,50$; for flfteen to twenty-flve cows, $\$ 4$.

Cheose-Iresses, $\$ 6.50$ to $\$ 7.50$.

Chisels, Grafting, 63 cents.

Edgingr-Knives, 75 cents to $\$ 1$.

Fanning-11ills, Allen's, \$18 to \$30; Grant's, \$21 to \$27; Clinton's, \$11 to \$15.

Flower Gatherers, $6 z_{y}$ cents to $\$ 1$.

Forges, Portable, $\$ 25$ to $\$ 10$.

Forks, Munure, Phœnix, Patridgo's, White's, Denning \& Hurt'3, and other makers', 75 cents to $\$ 3$.

Forks, Hay, various makers, 50 cents to $\$ 1.50$.

Fountains, \$10 to \$I50.

Garden Engines, $\$ 30$ to $\$ 50$.

Grain Drills, $\$ 100$ to $\$ 150$.

Grain Mills, Burr stone, tor horse, steam and water power, Nicholas \& Marsh's, 12-inch, $\$ 60$; 16-in., \$so; su-in., \$luo; 21-in., \$140; 30-in., \$175; Platt's Mills, from \$10 to \$25 lokd. Fitzgerald's, \$25. Allen's Improved Horse or Hand-Puwer Iron Mill, \$25; do. hand power, $\$ 5.50$ to $\$ 6.50$.

Grindstomes, sf to 3 cents per lb; on stand witl trendle and friction rollers, $\$ 7.50$ to $\$ 10$ each.

Garden or Field llollers, for hand, \$10 to \$16; for Lo:sc, 30 to $\$ 75$.

Guano, 9 to 3 cents per lb.

Hurrows, Geddes', 14toothed, $\$ 3.50 ; 18$ do. $\$ 10 ; 292$ do. $\$ 12 ; 90$ do. $\$ 13 ; 30$ do. \$14; squaren $\$ 5$ to $\$ 8$. Scotch or Double Square Harrows, $\$ 12 ;$ atso oller kinds at virious prices.

Horse-Hay likies, $\$ 7.50$ to $\$ 9$.

Ilorse Powers, Tuplin's 20 -foot circle, $\$ 80$ to $\$ 85$; Trimble's two-horse, S60); four-horse, $\$ 90$; Allen's Improved One-llorso Endless-Chain or Railway Power, S\$5; two-horse, sloj; Im. proved Iron, $\$ 80$ to $\$ 100$.

Hoes, a great varicty, $3 T_{\frac{1}{6}}$ cents to $\$ 1$.

Hammety, Anderson's patent, \$1 to $\$ 1.25$.

Lactometers, $\$ 2$ to $\$$ J.

Uowing Machines, $\$ 140$ to $\$ 160$.

\section{New-York Low-Priced Plowos.}

Ergle No. 1, \$5; No.,$\$ 5.50$; No. 1 13., \$1.50.

J. N. \& Co. No. 1,83 ; do. No. $2,83.50$; do. No. 3, $\$ 4.50 ;$ do. Ni). $4,55$.

Dutcher No. 11, st.50; do. Nu.

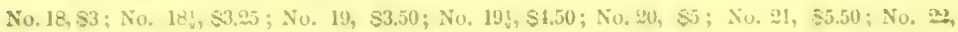
S6.50.

Three-Share Plowe, $\$ 5.50$ to $\$ 6.50$.

Largdon Potato l'low, so to 57.50 .

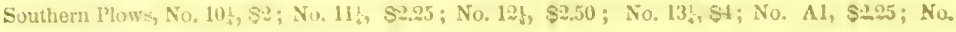
A2, $\$ 1.50$; No. $14, \$ 2,50$; No. $15, \$ 3$.

Caxt-iron Cuulters, an additional charge of 50 conts. IVith steel edjo and band, $\$ 1$. 
Worcester Improved, Eagle and other Plows.

\begin{tabular}{|c|c|c|c|c|c|}
\hline Plows. & Name. & 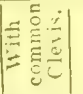 & $\begin{array}{c}\text { Wheel or } \\
\text { Cutter. }\end{array}$ & $\begin{array}{c}\text { Wheei and } \\
\text { Cutter. }\end{array}$ & $\begin{array}{c}\text { D. Rod } \\
\text { Wheel \& } \\
\text { Cutter. }\end{array}$ \\
\hline 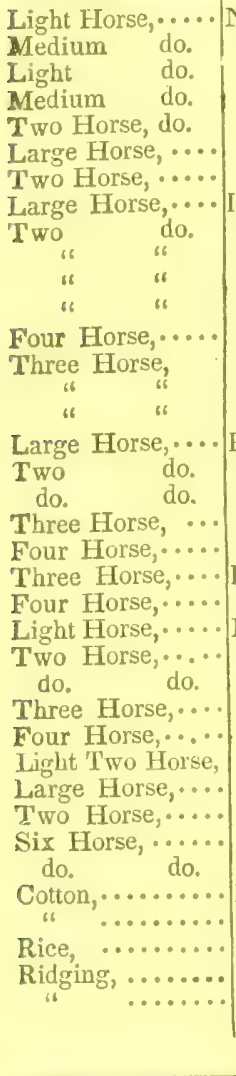 & 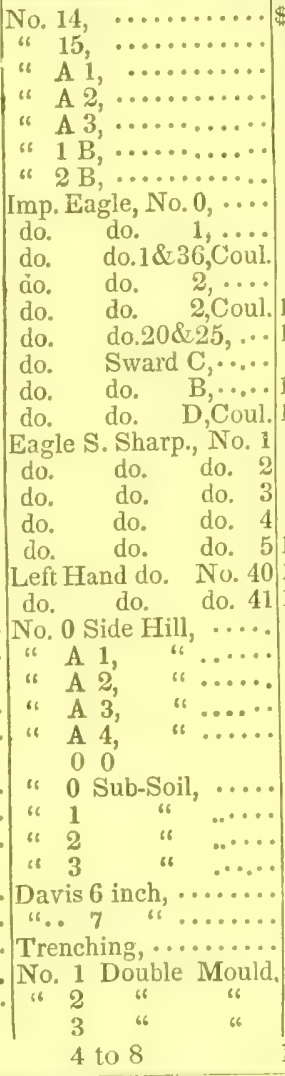 & 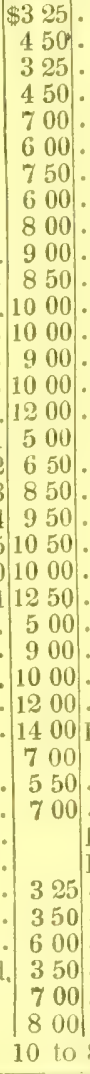 & 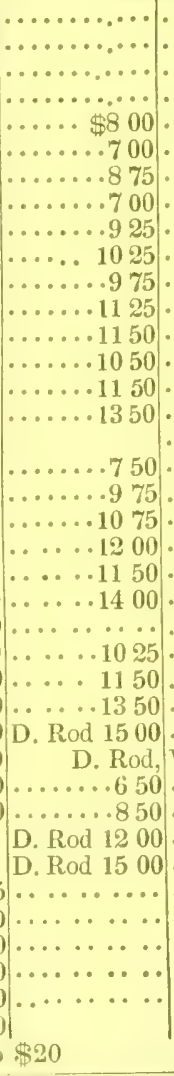 & 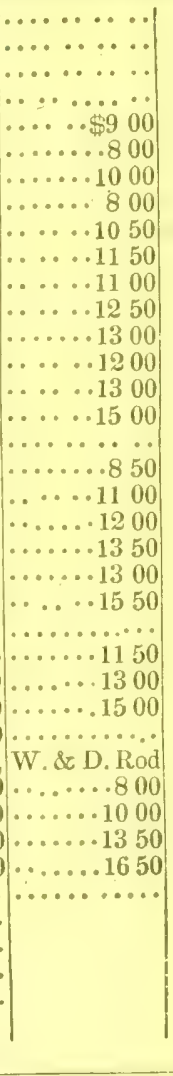 & $\begin{array}{ll}11 & 50 \\
12 & 50 \\
14 & 50 \\
14 & 00 \\
16 & 50 \\
& \\
12 & 00 \\
14 & 00 \\
16 & 00\end{array}$ \\
\hline
\end{tabular}

\section{Additional Highly-Finished Plows.}

No. $10 \frac{1}{4}, \$ 3 ;$ No. $11 \frac{1}{4}, \$ 3,50 ;$ No. $12 \frac{1}{2}, \$ 4.50 ;$ No. $13 \frac{1}{4}, \$ 7$.

Corn, $\$ 4$; seed, $\$ 4.50$.

No. 1, M. \& Co., \$1.50; No. \$, M. \& Co., $\$ 5.50 ;$ No. 3 , M. \& Co., $\$ 7.50 ;$ No. 4, M. \& Co., $\$ 9$. No. $18, \$ 1.50$; No. $18 \frac{1}{2}, \$ 5$; No. $19, \$ 5.50$; No. $19 \frac{1}{2}, \$ 7$; No. $20, \$ 7.50 ;$ No. $21, \$ 8$. 50 cents additional for Draft Rod, $\$ 1.25$; for Coulter and Wheel, $\$ 1.25$.

Bosides the above, we have very many other patterns.

Pumps, $\$ 3.50$ to $\$ 15$ and upwards, pipe extra.

Post-Spoons, $\$ 1.25$ to $\$ 1.50$.

Plaster of Paris, $\$ 1$ to $\$ 1.50$ per bul.

Poudrette, $\$ 1.50$ to $\$ 2$ per bbl.

Planing Machine, $\$ 75$ to $\$ 1,000$. 


\section{LIST OF PRICES.}

Pole Praning-Shears, $\$ 3$ to $\$ 5.50$.

Pruning-Saw and Chisel, \$:.

Pruaing-Scissors, 63 cents to $\$ 1.50$.

Pruning Sliding-slrears, \$2 to \$5.

Reaping-Vlachines, \$130 in \$170.

Rice-Threshers, $\$ \& 0$ to $\$ 100$.

lice-llullers, hand-power, 570 tc $\$ 75$; horso-power, $\$ 90$ to $\$ 135$,

Root-Pullers, 19 s cents per $1 \mathrm{tb}$.

Rukes, various kinds und prices

Seed-Sowers $\$ 8$ to $\$ 14$.

Scythes, Grain, Grass, Bush and Lawn, 75 cents to $\$ 1.25$.

Smut-2rachines, $\$ 60$ to $\$ 100$.

Straw and Hay-Cutters, Ruggles', Towers', Stevens' Ilorey's, Greene's \& Langlon's, \$7 to \$25;

IIand-cutting box, $\$ 3$.

Stalk, Straw and Hay-Cutters, Sinclair's 2 -inch, $\$ 25 ; 11$-inch, $\$ 28 ; 14$-inch, $\$ 15$; Bott': No. $1, \$ 2 \bar{J}$,

Todd \& Marshall's, \$12.

Serapers, Foad or Ox, $\$ 4.50$ to $\$ 8$.

Sausage-Stuffers, $\$ 4.50$ to $\$ 5$.

Sausage-Cutters, $\$ 5, \$ 10$ to $\$ 15$.

Sugar-Crushers, \$10 to \$ะ5.

Shovels and Spades, a good assortinent, i5 cents to \$1.25.

Sicales, $\$ 7$ to $\$ 50$

Saw-Mills, portable, $\$ 300$ to $\$ 1,500$.

Sueathes, 50 cents to $\$ 1$.

Scunlers, or I) utch Hoes, $37 \frac{1}{3}$ cents to $\$ 1$.

Threshers, Allen's onc-hore, $5: 28$; do. with Separatcr, $\$ 35$; two-horse, do. $\$ 35$ to $\$ 50 ;$ Taplin's, $\$ 40$; Whitenau's do. wilh Feparator and Clenner, for one or two horses, \$100; Trimble's \&25: Warren's s:5.

Trucks, $\$ 3.50$ to $\$ 10$.

Tool.Chest, Horticultural, $\$ 18$ to $\$ 30$.

Do. Carpenter's. Stu to $\$ 1.50$.

Trowels, transplantines. 50 to 75 comte.

Fegetable-ciuters, siz.

\section{ADDENDA.}

Forks, Weedins, 37$\}$ to 75 conts.

Glacs Milk Pans, s? lo \$12 per dozon.

Rakes, Cranberry, $\$ 1.75$ to $\$ 2.50$.

6 Floral, $3 \% \div$ to 50 cent.

Tree Scrapers, $37 \frac{1}{4}$ to 62 cents. 


\section{PRICES}

\section{of \\ UNENU M ERATED ARTICLES.}

Axes, Collins's, Hunt's, Simmon's, Davis's, and other various patterns, $\$ 1$ to $\$ 125$, Axes, half, 50 to 75 cts.

Augers, Post-hole, $\$ 4$ to $\$ 5$.

Apple-Parers, 75 to $\$ 250$.

Beams, Scale, $50,100,150,200$, and $250 \mathrm{lbs}$. $\$ 225$ per beam; 75 cts. for each at. litional hundred.

Bows, Ox, 25 to 50 cts. per pair.

Brushes, Caterpillar, 31 cts. each.

Brushes, Horse, 75 to $\$ 125$ each.

Bow, Ox, Keys, $12 \frac{1}{2}$ to $25 \mathrm{cts}$. per pair.

Books, Agricultural and Horticultural. (See list of Prices.'

Cheese-Hoops, 25 cts. each.

Cattle-Cards, brass and iron, 25 to 50 cts.

Chains, Ox and Log, 9 to $12 \frac{1}{2}$ cts. per lb.

Chains, Trace, 50 to 75 cts. per pair.

Do. Dog, Halter, Cattle-ties, \&cc., 25 to 50 cts.

Crowbars, 8 to $10 \mathrm{cts}$. per $1 \mathrm{~b}$.

Corn-Hooks, 50 cts, each.

Chairs, ornamental iron, for gardens, 450 .

Clover-Hullers, $\$ 20$ to $\$ 80$.

Curry-Combs, Crank's various kinds, \&c.

Ditching-Spades, 75 cts. to $\$ 125$.

Engines, Steam, $\$ 300$ to $\$ 2500$.

Engines, Plantation, $\$ 40$ to $\$ 150$.

Furnaces, Agricultural, $\$ 9$ to $\$ 50$.

Flails, 63 to $87 \mathrm{cts}$.

Fleams, 38 to $50 \mathrm{cts}$.

Grass Hooks, 38 to 63 cts.

Grindstone-Rollers, 75 cents to $\$ 2.50$ per sets. 
Grafting-Saws, $63 \mathrm{cts}$. to $\$ 150$.

Garden-Recls, 75 cts.

Garden-Lines, $25 \mathrm{cts}$.

Grain-Measures, $\$ 1$ to $\$ 2$ per sett.

Garden-Pumps, Cooper's, $\$ 550$.

Garden-Syringes, \$1 to $\$ 6$.

Gin-Gear castings, $23-1$ to 4 1-2 cts per la

Grape-Cutters, $50 \mathrm{cts}$, to \$2 50.

Hammers, $75 \mathrm{cts}$. to $\$ 150$ each.

Hooks, Potatoe, $50 \mathrm{cts}$. to $\$ 150$.

Hooks, Manure, $75 \mathrm{cts}, 10 \$ 1$.

Handles, Hoe, Shovel-Fork, \&c.

Hay-Presses, „jo to \$125.

Hatchells, \$10 to $\$ 30$ per set.

Knives, Hay and Straw, \$1 to \$1 50 .

do. Budding and Pruning; $50 \mathrm{cts}$. to $\$ 1$.

do. Cane, 50 cts. to $\$ \mathbf{1} 25$ each.

do. Peat and Ditching, $\$ 1$ to $\$ 2$ each.

do. Farrier, 38 to $50 \mathrm{cts}$.

Knobs, Ox, $12 \frac{1}{2}$ tu $25 \mathrm{cts}$.

Lime, 4 to $8 \mathrm{cts}$. per bushel.

Mízzles, Ox, 38 to 75 cts, per pair.

Mattocks, handled, $\$ 125$ to $\$ 150$.

Mills, Paint, $\$ 6$ to $\$ 16$.

Morticing-Machines, $\$ 20$ to $\$ 50$.

Pichaxes, $75 \mathrm{cts}$, to $\$ 125$.

Potatoe-Hooks and Fork, $50 \mathrm{cts}$. to $\$ 150$.

Rifles, Scythe, 6 to $12 \frac{1}{2} \mathrm{cts}$. each.

Rat-Traps, $75 \mathrm{cts}$.

Rollers, $\$ 150$ per set.

Rein-snaps, $12 \frac{1}{2}$ to $25 \mathrm{cts}$.

Riddles, Fan, $75 \mathrm{cts}$. to $\$ 1$.

Sickles, 38 to 75 cts.

Stones, Scythe, Quinebaug, and Indian pond, $6 \$$ to $19 f \mathrm{eca}$

Shears, Sheep and Horse, $75 \mathrm{cts}$, to $\$ 125$.

Saws, Circular, \$5 to \$25.

do. Crosscut, $\$ 1$ to $\$ 10$.

do. Hand, \&c., $75 \mathrm{cts}$. to $\$ 1.50$.

Twig-Culters, 50 cts, to $\$ 2$.

Tallies, Garden, $\$ 22$ to $\$ 350$ per hundred.

Vases and Urns, ornamental for gardens.

Whiffletrees, double, $\$ 3$ to $\$ 350$; single, \$1 to $\$ 150$.

Wrenches, patent, \$150 to \$350

ćo. Malleable, 50 cts.

Wood-Sinwing Machines, $\$ 35$ to $\$ 50$. 
LISI OF PRICR.

Wheel Heads, 50 to $75 \mathrm{cts}$.

Well Pulleys, $\$ 1$ to $\$ 125$.

Washing-Machines, $\$ 5$ to $\$ 10$.

Wagons Farm and Plantation, $\$ 70$ to $\$ 1: 25$.

Wheels, Cart and Waggon, $\$ 30$ to $\$ 50$ per pair.

Yokes, Neck, $\$ 2$ to $\$ 225$.

do. $\mathrm{Ox}, \$ 1$ to $\$ 150$, ironed $\$ 2,50$ to $\$ 5$.

Vanes, $\$ 10$ to $\$ 25$.

通 $\Lambda$ liberal discount made from the above prices, at wholesale.

Machinery \&tc., furnished to order.

\section{Prices of Grasses and clovers.}

Blue Grass, per bushel, $\$ 2$ to $\$ 3$.

Herds Grass, or Red Top, per bushel, \$1 to $\$ 150$.

Lucerne, per $1 b .25$ to 35 cents.

Orchard Grass, per bushel, $\$ 2$ to $\$ 250$.

Ray Grass, per bushel, $\$ 3$.

Red Clover, per lb. 7 to 10 cents.

Tall Oat Grass, \$3.

Timothy, per bushel, $\$ 2$ to $\$ 4$.

White Clover, per $1 \mathrm{~b} .25$ to 35 cents.

In our assortment of Garden Seeds may be found the varieties mentioned belc. r $_{\text {, }}$ with others not included.

ARTICHOKE, Green Globe,

ASPARAGUS, Giant,

ENGLISH BEANS, Windsor,

Early Long Pod,

DWARF BEANS, Early China,

Early Valentine,

Early Yellow Six Weeks,

Early Mohawk,

Large White Kidney,

Refugee, or Thousand to One,

POLE BEANS, Dutch Case Knife,

Horticultural Cranberry,

Large Lima,

Saba, or Carolina Lima,

Scarlet Runner,

White Dutch Runner,

Red and White Cranberry,

BEET, Best Early Blood Turnip

Early Yellow Turnip,

Early Scarcity,

Long Blood Red,

Smooth Long Dark Blood,

White Sugar,

Mangel Wurtzel,

BROCOLI, Early White,

Early Purple,

Large Purple Cape,

White Cape or Cauliflower,

Chappell's New Cream Color:d BRUSSELS SPROUTS,

CABBAGE, Early York or Jun:

Early French Oxheart,

Early Sugarloaf,

Early Flat Battersea,

Large York,

Large Drumhead Winter,

Large Flat Dutch,

Large Bergen or American,

St. Denis Drumhead,

True Green Glazed,

Green Globe Savoy,

Fine Drumbead Savoy,

Red Dutch,

Kohl Rabbi, above ground,

C AULIFLOWER, Early London,

Large Late,

CARROT, Early Horn,

Long Orange,

Altringham,

Large White Ficld,

CELERY, White Solid,

New Silver Giant, 
Large Manchester Red,

COLEWORT' or Collards,

CORN SALAD or Fetticus,

CRESS, Curled, or Yeppergrass, Broad Leaf,

Water or Winter,

CUCUMBER, Early Frame, Early Cluster,

Early White Spine (very fine),

Short Prickly,

London Long Green,

Extra Long Green Turkey,

Gherkin or West India,

EGG PLANT, Purple,

ENDIVE, Green Curled, Broad Leaved Batavia,

CORN, Sweet or Sugar,

Early 'I'uscarora,

Early White Flint,

KALE, Green Curled Scotch, Sea,

LEEK, Large Scotch or Flag, London,

LE'T'TUCE, Early Curled Silesia Early White Cabbage,

Brown Dutch,

Large Green Head,

Fine Imperial Cabbage,

Brown Silesia Head,

Large India,

Butter, or Summer,

Ice Coss,

Paris Green Coss,

Fine Mixed Lettuces,

MELON, Green Citron,

Nutmeg,

Pine Apple,

Skillman's Fine Netted,

Persian,

Large Yellow Cantaloup,

Large Musk

Long Island Water.

Mountain Sprout,

Citron Water for preserves,

MUSTARD, White or English, Brown,

NASTURTIUM,

ONION, Wethersfield, Large Red, Yellow Dutch

Yellow Silver Skin,

White Portugal

OKRA, Green and White,

PARSLEY, Plain or Common, Curled or double,

PARSNIP, Long Smooth,

PEAS, Early Warwick,

Early Frame or June,

Early Washington,

Early Charlton,

Early Double Blossom,

Dwarf Blue Imperial,
Large White Marrowfat,

Dwarf Marrowfat,

Green Marrowfat,

PEPPER, Cherry,

Long or Cayenne,

Tomato-shaped or Squash,

Large Bull-nose,

Large Sweet Spanish,

PUMYKIN, Connecticut Field, Large Cheese,

RADISH, Wood's Early Frame, Early Short-top Long Scarlet,

Long Salmon

Early Scarlet Turnip,

White Turnip,

Yellow Turnip,

Black Fall Spanish,

RAPE, for Greens,

RHUBARB, Early Tobolsk,

Myatt's Victoria,

SPINACH, Round or Summer, Prickly or Fall

SALSIFY, or Vegetable Oyster,

SQUASH, Early Yellow Bush Scollop, Early White Bush Scollop,

Early Bush Summer Crookneck,

Green Striped Bergen,

Fall or Winter Crookneck,

Autumnal Marrow,

Lima Cocoanut,

'TOMATO, Large Smooth, Red,

Large Yellow,

Small Yellow,

TURNIP, Early Flat Dutch or Spring

Early Snowball.

Early Red-top Flat,

Early Garden Stone,

Red and White Top Strap-leaf,

Large Flat,

Large English Norfolk,

Pomeranian White Globe,

Long White, or Cow Horn,

Long Tankard or Hanover,

Yellow Stone or Orange,

Yellow Aberdeen, or Bullock,

Long Yellow French,

Purple-top Ruta Baga,

Asparagus Roots

Red Onion Sets,

Garlic,

Seeds in Papers,

The above furnished in any quantity.

Prices of these are so subject to variation we cannot well give them. 


\title{
AGRICULTURE AND RURAL ECONOMY,
}

\author{
FOR SALE BY
}

\author{
A. B. ALLEN \& CO.,
}

191 WATER ST., NEW YORK.

American Flower Garden Directory. \$1 25. American Shepherd. \$1.

American Farmer's Encyclopædia. 84.

American Florist. 38 cents.

American Poulterer's Companion. \$1.

Allen's Domestic Animals. 75 cents.

Allen's Compend of Agriculture. \$1.

Allen's Treatise on the Grape. 62 cents.

Allen's American Herd Book. \$3.

American Poultry Book. 37 cents.

A merican Husbandry. $\$ 1$.

American Turf Register and Stud Book. By P. N. Edgar. $\$ 2$.

Boussingault's Organic Nature. 50 cents.

Buist on the Rose. 75 cents.

Buist's Kitchen Gardener. 75 cents.

Bridgeman's Young Gardener's Assistant, new edition, much enlarged. \$2

Bridgeman's Fruit Cultivator's Manual. 62 cents.

Bridgeman's Kitchen Gardener. 62 cents Florist's Guide. 62 cents.

Bees, Pigeons, Rabbits, and the Canary Bird, familiarly described. $371 / 2$ cents.

Browne's Trees of America. \$5.

Browne's American Poultry Yard. \$1.

Cattle, Treatise on, \$3.

Clater and Youatt's Cattle Doctor. 50 cents.

Cole on the Diseases of A nimals. 50 cents.

Chemistry Applied to Agriculture, by M. Le Comte Chaptal. 50 cents.

Complete Farmer and Rural Economist, by Thomas G, Fessenden. $7 \dot{b}$ cents.

Dana's Prize Essay on Manures. 1212 cents.

Downing's Fruit Trees. \$1 50 .

Landscape Gardening. $\$ 350$.

Cottage Residences. $\$ 2$.

Every Lady her own Flower Gardener. 39 cents.

F.very Man his own Gardener. 25 cents.

Ł.ssays on Practical Agriculture, by $\Lambda$ dam Beatty, of Kentucky. \$1.

Fassenden's American Garilener. 80 cents.

Farmer's Instructor. By J. Buel. 2 vols. \$1.

Farm liock R. I. Allen. \$1.

Fruit Culturist, by J. J. Thomas. 62 cents.

First Lessons in Botany. 25 cents.

Grav's Botanical Text Book. \$1 50 .

Gartner's Farmer's Dictionary. \$1 50.

Gatening for Ladies, and Companion to the Flower (iarden, by Mrs. Loudon. \$1 50.

Hind's fauriery. 75.

Hawker on Shooting $\$ 250$.

Hoare ou the Vine, 63 cts.

Ho "se, its Habits ard Management. $25 \mathrm{cts}$
Honey Bee, its Natural History, Sc.. with 35 engravings. 31 cents.

Ives' New England Eruit Book. 62 cents. Johnson's Agricultural Chemistry. $\$ 12.7$.

Johnson's Modern Gardener, \$2 25.

Johnson's Catechism of Agricultural Cne mistry and Geology. 25 cents.

Know'son's Cattle or Cow Doctor. 25 cents.

Lang's Highland Cottages, \$1 50 .

Liebig's Agricultural and Animal Chemistry. 25 cents each

Liebig's Familiar Letters on Chemistry. $121 / 2$ cents.

Loudon's Ency clopædia of Agriculture (Eng lish). $\$ 10$

Loudon's Encyclopædia of Gardening. \$14. " Villa and Cottage Architecture. $\$ 1 \%$ " Encyclopædia of Agriculture.

"S Suburban Gardener. \$6.

"Trees and Shrubs. \$14.

Trees and Sh
Plants. \$\$20.

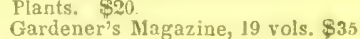

Hortus Britannicus. $\$ 12$.

Mnck Manual for Farmers. 50 cents.

Miles on the Horse's Foot. 25 cents.

Mason's Farriery. \$1.

New American Orchardist, by Wm. Kex rick $5 i 1 / 2$ cents.

Parnell's Applied Chemistry. \$1.

Ruschenberger's Horsemanship. \$1

Rural Economy. By Boussingault. \$1 30 .

Spooner on the Grape. 38 cents.

Stable Econony, by Stewart. Revised by A. B. Allea. $\$ 1$.

Stewart:s Planter's Guide. \$1 25.

Stable Talk. \$1.

Stewart on Drainage. \$1 25.

Sheep, A Treatise on. By A. Blacklock. bue

Stock Raiser's Mianual. \$3.

Townley on the Honey Bee. 50 cents.

Taylor's Bee-Keeper's Manual. \$1 25.

Treatise on Milch Cows. 38 cents.

Torry's Flow of N. America. \$6.

Ure's Dict. of Arts, Manufactures, \&c. \$0.

Vegetable Kingdom, or Hand Book of Plants. $\$ 125$.

Youatt on the Horse; a new edition. \$1 7s

Youatt on the Dog. \$1 50.

Youatt on the Pig. 65 cents. 
TIIE

\section{AMIEICICAN WARM TPOOK,}

$0 \mathrm{R}$

\section{COMPEIND OF AMERICAN AGRICULTURE,}

CONTAINIX A CONCISE AND PT.ANT,Y-WTITTEN EXPOSITION OF DUTIES PERTAINING TO THE CULTIVATION OF THE EARTI, THE MANAGEMENT OF THE FARM, \&c., dec, ON PlAACTICAI, SCIENTIFIC PRINCIPLES.

\section{BY R, I, $\mathrm{Y}$ I, L, E N .}

The cheapest and most valuuble book for a furmer ever printed; being a complete guide, both practical and scientific, for the

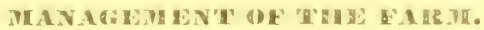

Besides the varied practical knowledge which this book imparts, and which is indispensable to the proper manigenent of every department of agriculture, it gives the elements of other information highly necessary to a successful farmer, as llistory, Geologry, Chemistry, Botany, Physiology, and Mechanics. 'These branches of knowledge are given as applicable to agricultural pursuits, and when properly understood will essentially aid and assist the furmer. In fact, a knowledge of these sciences is a sure key to wealth for any agrieulturist. It gives the modes of preparation, and the ellects of all kinds of manures; the origin, texture, divisions, and description of cver'y rariety of soil ; the economy of sowing, reaping, and mowing, irrigation, and draining; cultivation of the grasses, clovers, grains, and roots; Southern and miscellineous products, as cotton, hemp, flax, the sugar cane, rice, tohaceo, hops, maduer, woad, Sc.: the rearing of fruit-ipples, pears, peaches, plums, grapes, \&c.; firm luildings, hedges, \&c.; with the best methods of planting, cultivating. and preparation for markct. Illustrated by 100 cngravings.

'The reader can form some inlea of the above work, from the fatet that it treats of 800 different subjects important to a fiurmer. It contains 35.1 palges: and is beatifully bound in cloth, suitable for a libraty. Price only One Dollar.

\section{NOTICES OF THE PRESS.}

The author has been one of the most able contributors to the arricultuml preas for the fwo the

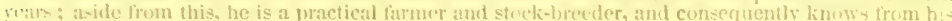
in $n$ experience what he is writing about.-Commercint Adectiser.

This work is loy a Lemteman of known experience; the work is excendingly cheap, and the

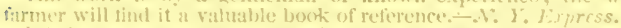

It is in last a brief eneyclopedia on the sulyeets treated, and the fitmer will find appropriate.

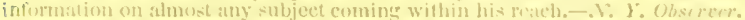

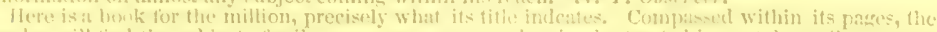
reader will find the subject of soils, manteres, crojes, tud animals, treated in a style easily compre heruled.-2: 1: Spririt of the times.

This work is what miglit be expeeted from one so well qualified lor the nudertaking.-Bostun Ciltivatur.

Why shalf not every good farmer economise his museley by sioring his mind? We hope thia houk will tind it way into many tamily and school libaries, - V: Y. Trilume.

We think that Mr. Mllen's volume, the basis of which is good practical farming, as practised by the best cultivators in the l'nited Nates, with an intrllicent reterence to tluse principles of seience which lie at the roent of atl sncesstul ractice, is likety to be of as nuch or more reat service wo nu

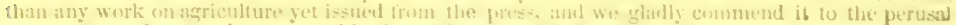
of every one of our renders enguged in the cultivalion of the land.-Furticulerist. 
EXTENOSTVE MANUFACTORY AND MACHTNE SHOP.

Connected with our Warehouse, we have a large Manufacturing Es tablishment, for the purpose of making various kinds of Agriculturat and other Implements and Machinery. Those wishing implements, got up differently from what is already manufactured by us, have only to send us a model or plain drawing of the Implement or Machine, with a description, and we will make it according to order.

A. B. ALLEN \& CO. 


\section{DESCRIPTIVE CATALOGUE}

of

\section{A GRIOULTURAL A ND IIOERTICULTURAL}

$$
\text { IMPLEMENTS, }
$$

$A N D$

\section{FIELD AND GARDEN SEEDS;}

WITH BRIEF DIRECTIONS

TOR PIOWING, PLANTING, SOWING, AND CULTURE; WITH RULEO FOR TIE APILICATION OF GUANO, LIME, PLASTER, BONE-DUST, AND OTHER MANURES;

\section{ALSO, DIRECTIONS TOB}

PLANTING ANT CUITIVATIXG FRUIT-TRELS. WITH A DESCRIPTIOA OT THE

BEST BREFDS OF DONESTIC ANIMIALS,

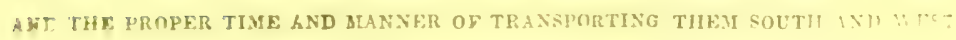

\section{THIRTEENTH EDITION.}

NEW YORK.

A. B. A L L E N \& C 0.,

NEW TORE AGRICULTURAL WAREHOUSE, 191 WATRR STREET.

1851. 
Fntered according to Act of Congress, in the year 1848 , by A. B. ALLEN, \& Co.

in the Clerk's Office of the District Court of the United States for the Southure District of New York.

Persuns from a distance ordernge such articles as may be illustratod by cuts, will please to specify from which edition of our Catalogues they are taken. 


\section{DESCRIPTIVE CATALOGUL.}

PLOWS.

THE plow is the most important implement on the farm. It is now Eenerally made of cast-iron, and this is not only much the cheapest, but for prdinary use, it is also the best. The point, being of cast-iron, is ensily replaced at a moment's notice, and with trifling expense, when either broken or worn out; and, in consequence of being made from a mixture of several kinds of the best metal, it has the tenacity, strength, and durability of the best steel. There are upwards of sixty different kinds of plows kept in this Agricultural IVarehouse, among which are the Loot-Breaker, Prairie, Swarl, Mleatow, Stubble, Self-Sharpener, Centre-Dranght, Corn, Cotton, Rice, Sugar-Cane, DoubleMould-board, Trenching, Paring, Ditching, Side-Fiill, Horizontal, and SubsoilPlows. They are of various sizes, from one horse to six, and are calculated for all kinds of soils. Some of these plows have the common, and some the Scotch clevis; some have the draught-rod, while others have a crane-clevis attached, so that the team can walk on the sward instead of a wet furrow, or the plows can rum close by the side of a fence or ditch. The prices vary from $\$ 2$ to $\$ 20$, according to the size and finish.

\section{REMARKS ON PLOWING.}

From the complicated structure of the plow, and the manner in which circumstances oblige us to apply the draught to the implement, some misconceptions have arisen as to the true operation of the draught, and the proper manner of its application. Too little is understood of the true principle of draught, to cnable the plowman to attach his team and arrange the clevis so that the plow will do its work properly, and with the least force or power. To render this subject intelligible to every mind, the following remarks are made in connexion with the plate annexeil, Figure 1.-[See next pagre.]

Let $b$ represent the forward end of the beam, and $c$, the centre of resistance on the plow, which may be assumed at 2 inches above the plane of the base of the plow, $d e$, though it is liable to constant changes from the depth of the furrows, and constant inequalities in the soil. 

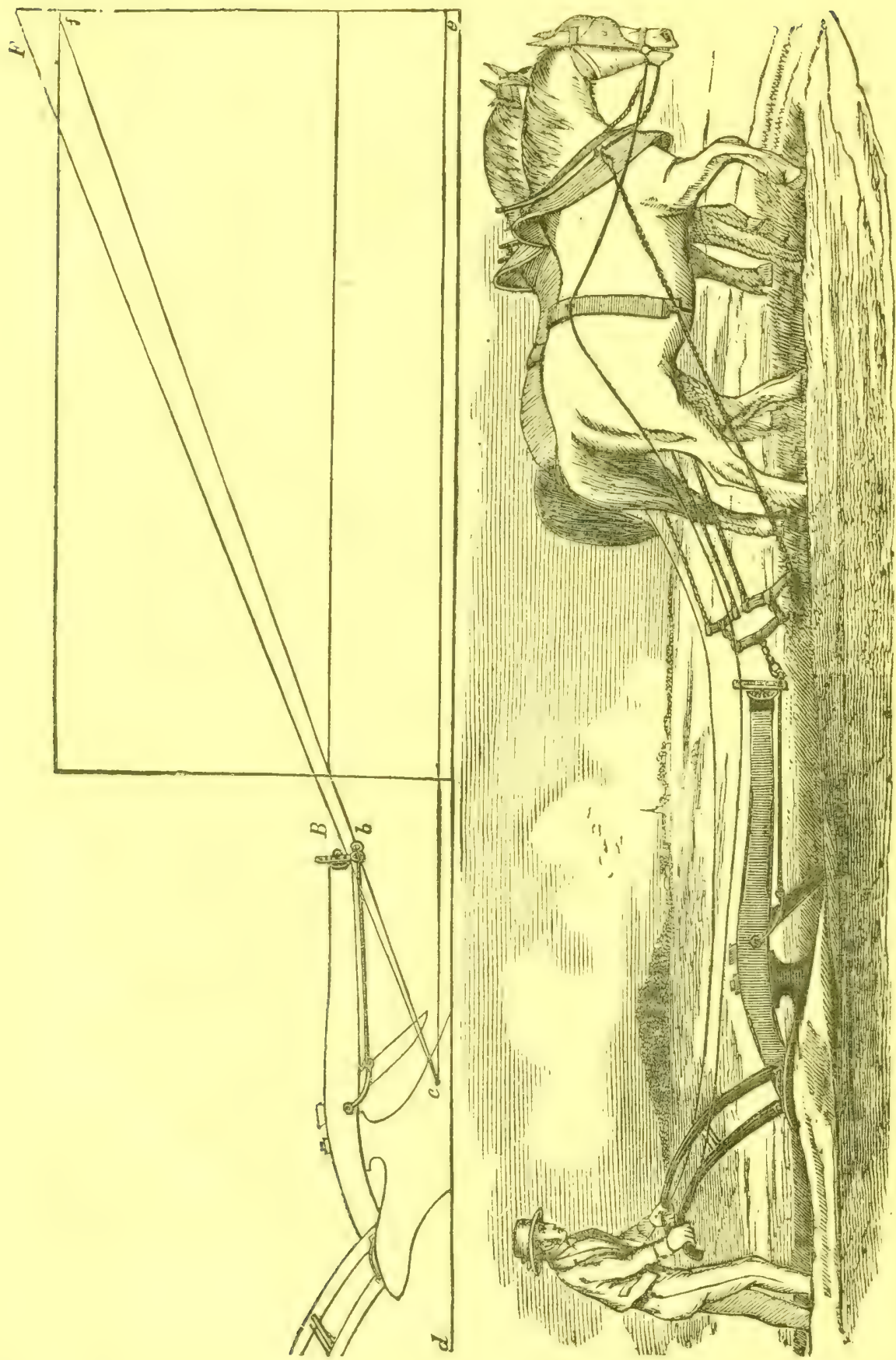
We have first to consider the particular form of those parts through which the motive power is brought to bear upon the plow It is evident that. the motive force acts in a direct line from the hook or ring at the shoulder of the animal, to the centre of resistance, and were it not for considerations of ronvenience, a straight bar or beam lying in the direction $c b$, and attached firms y to the body at $c$, would answer all the purposes of draught perhapt better than the present beam. But the draught not heing the end in view, but merely the means by which the end is accomplished, the former is made to subserve the latter; and as the beam, if placed in the direct line $c$ to $b$, would obstruct the proper working. of the plow, we are constrained to resort to an indirect action to arrive at the desired effect. This indirect action is accomplished through the medium of an angular frame-work, consisting of the beam and the body of the plow, so strongly connected together as to form an unyielding structure. The effect of the motive force applied to the frame-work at the point $b$, and in the line of $b$ to $f$, produces the same results as if $c b$ were firmly connected by a bar in the position of the line $c$ to $b$, or as if that bar alone were employed.

The average length of the trace chains being 10 feet, including all that intervenes hetween the clevis of the plow at $b$, and the horse's shoulders, let that distance be set off in the direction $b$ to $f$; and the average height at the horse's shoulders where the chains are attached, being about 4 feet 2 inches, let the point $f$ be fixed at that height above the base-line $d e$. Draw the line from $f$ to $c$, which is the direction of the line of draught acting upon the assumed centre of resistance, $c$; and if the plow is in proper trim it will coincide also with the ring of the clevis; $e c f$ being the angle of draught, and equal to $20^{\circ}$. It will be readily perceived, that with the same length of hames, the angle $e c f$ is invariable; and if the plow has a tendency to rise at the heel, or run on the point, under this arrangement, it indicates that the ring at $b$ is too high in the clevis. Shifting the ring one or more holes downward, will bring the plow to work evenly upon the base of the landside, or work flat.

If the plow has a tendency to rise at the point of the share, the ring $b$ is too low, and must be moved by raising it one or more holes in the clevis. If a pair of taller horses be harnessed to the plow, the draught-chains, depth of fur. row, and soil (and, by consequence, the point of resistance $c$ ), remaining the same, we should have the point $f$ raised, suppose to $F$; by drawing the line $F$ to $c$, we have $e c F$ as the angle of draught, which will now be $22^{\circ}$, and the ring will be found to be below the line of draught $F c$; and if the draught chains were applied at $b$, in the direction $F b$, the plow would have a tendency to rise at the point of the share, by the action of that law of forces which obliges the line of draught to coincide with the line which passes through or to the centre of resistance; hence the ring $b$ would be found to rise to $b$, which would raise the point of the share out of its proper direction. To rectify this, the ring must be raised in the clevis by a sirace equalling that between $b$ and $B$, causing it to coincide with the true line of draught, which would again bring the plow to work evenly on the base of the landside, and run flat. 
The foregoing principles are substantially such as are adopted by the most experienced plowmen, and, if properly applied, will not only do the best work, but accomplish it with the greatest ease to themselves and their team. If the power (or team) is not rightly applied, good work cannot easily be done; for if the plow inclines in or out of the ground too much, or takes too wide or too narrow a furrow slice, the plowman must exert force to direct it properly, in addition to that required to overcome the obstacles and inequalities in the soil, but if the power be rightly applied, the plow will move so accurately as not only to perform good work with more ease to both plowman and team, but, in soils free from obstruction, even without being guided.

To effect a proper horizontal movement, the clevis al $b$ or draught-rod (if one is used instead of a clevis) must be adjusted and confined at that point, moving it to the right or left, if necessary. This will cause the plow to take the proper width of furrow slice, which, in sod, should be wider or narrower according to the depth of furrow, or rather the thickness of the furrow slice required; for as the thickness is increased so also must be the width, in order to turn it easily and perfectly over, particularly when the furrow slices are required to be laid over level and side by side. The proportion in ordinary sod should be 6 by 12 inches, or 7 by 13 inches. In determining the width of furrow slice, some regard must be had to the strength of the particular sod to be turned; for the same plow will turn over a wider slice in a strong or stiff sod, than when running in one more easily broken, or it will cripple and double when raised to a perpendicular position, thus only doing the work called "cut and cover." When the slices are required to be laid at an angle, and lapped each one upon the preceding, the proportion of width should be less, or about 6 by 10 inches; for the narrower the slice in proportion to the depth, the greater will be the inclination of the slice as it is lapped upon the preceding one.

The Cutter.-Simple as it appears to be, this is a very important appendage to the plow, as it cuts the furrow slice from the main land with great ease and precision, requiring much less power of team than when the slice is broken or torn off (which is always done when a cutter is not used), and the precision adds much to the quality and beauty of the work, leaving the slice true and straight upon the edge. Much depends upon the cutter being properly formed, and set so as to cut the furrow slice in the shape best adapted to turn and lie as required. The cutter can be raised or lowered at pleasure, to cut shallower or deeper, or it can be detached entirely, which always should be done in plowing rocky, or very rough or rooty land. The cutter is very useful at the South in cutting up the crab, and other tough grasses, thus enabling the plowman to cover them up completely with the furrow.

In order to turn the furrow slice completely over, and do what is termed flat-work, or planing, the cutter should pass down from the centre of the beam, about three inches forward and above the point of the plow, standing out in a line with the face of the landside, so that by placing a straight edge along the face of the landside, and forward past the cutter, it shall touch the point of the cutter. This position causes it to cut slightly under the improved iand 
and leave the furrow slice bevelling upon the edges, and when turned over the upper corner will have receded a little from the sod land, and thus admits the succeeding slice to drop in flat by its side.

To lay the furrow slices inclining, and lap them one upon the other, the cutter should pass down perpendicularly from the landside of the beam in such a way as to cut the edges of the slice at right angles with the sides. Whether the cutter be attached at the side or through the beam, it can be bent so as to stand in either position.

The Wheel.-Many advantages are realized in the use of the wheel on the plow, particularly in turning sod. It serves as a gauge to regulate the depth, and can be raised or lowered as required. It admits of the plow being drawn by a proper length of chain in any soil; and, with the aid of the wheel, the plow moves steadily and accurately along, being less affected by any irregular movement of the team; thus performing the work more uniformly, and with greater ease both for plowman and team, and the plow is thereby thus drawn at a convenient distance from the team.

The Draught-rod.-By the use of the draught-rod, the liability to break the beam is greatly diminished; and being placed so far from the end, it is not liable to be pulled out when doing heavy work; and another advantage is, the gauge of the plow is more easily, accurately, and surely fixed with the draught-rod than with a common cleris.

The Dul-clers is a recent improvement, which is shown in Figure 2. By the use of this, in connexion with the draught-rod, the plow can be made to perform its work at any required aistance on either side of the team, and the depth of the furrow can be ganged to any depth. This will enable the plow to work close up to the fence, or the side of a ditch, or turn a furrow in is appropriate place, while the team are walking on the sod, or unplowed ground.

Advantages of the Improved $\%$ low. - There are three prominent advantages in the use of the best molern improved plows. 1. They are smoother and better made, and more durable, without costing as much as the old-fashioned plow. 2. They do the work much more effectually, cutting a deeper, wider, more even, and truer furrow. 3 They will do the work with much less expenditure of team power. They will also, when properly constructed, pulverize the earth as they lift and turn it over, thus effecting that minute and general separation of the particles of the soil, which is so essential in preparing it for the ready admission of the rootlets of the plants, and enabling them to draw their food from every portion of it. Another alvantage consists in the fact, that all the parts of the plow, both wood and iron, are made from the same moulds, and are therefore all precisely alike. When any part gives out, it can easily be replaced by other parts which have been made by the manufacturer, and which may always be purchased with the plows 


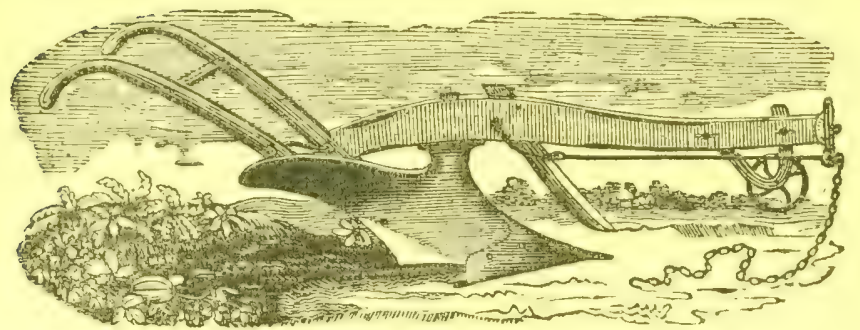

FIG. 2.

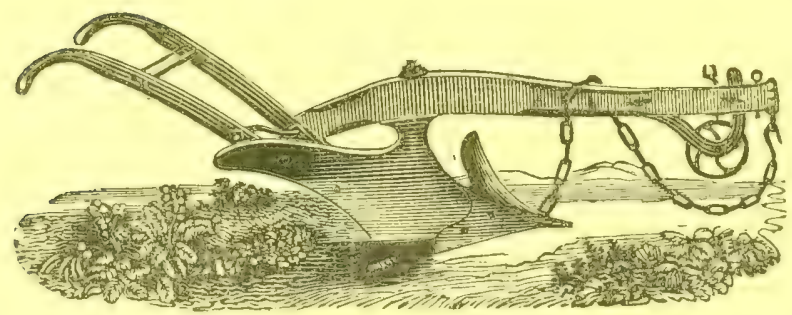

Filis, : 3.

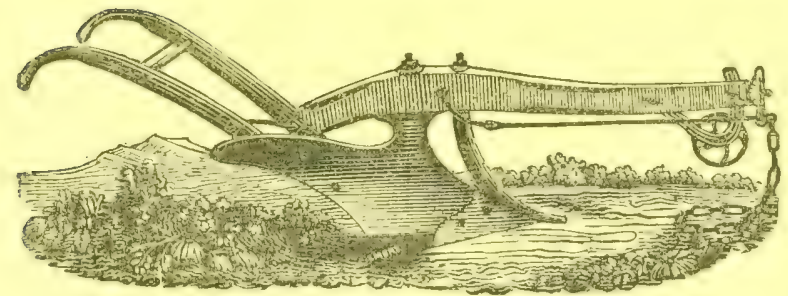

FIG. 1.

\section{Explanation of Cutter, Coulter or Fin-Cutter, and Lock-Coulter}

It is proper here to explain the difference between a culter, a coulter or fineutter, and lock-coulter, as the terms are loosely used by many as synonymous.

The Cutter, in Fig. 2, is of wrought-iron, edged with steel of the best quality. It passes through a mortice in the centre of the beam, where it is fastened by an iron clamp, and reaches down nearly to the point of the share. It can be raised or lowered at pleasure, or be taken out of the beam entirely. It is also clasped on the side of the beam when required.

The Coulter or Fin-Cutter, in Fig. 3, is caston to the point of the plowshare and thus forms a part of it. 
The Lock-coulter, in Fig. 4, is also made of wrought-iron, stecl-edged. It passes through the beam, and is made fust with a nut and screw or key, and locks through the point and mould-board where they join. This gives it great strength, and makes the plow suitable to be used among rocks, and especially the roots of newly-cleared land, for the lock-coulter cannot be turned on one side nor fored out of its place.

The Cutter, Coulter or Fin-Cutter and Wheel are applicable, and are attached when desired, to all sizes of plows, excepting the smaller sizes; and one or all are used upon the same plow as may be desired.

\section{DESCRIPTION OF THE GENUINE \\ IMIPROVED EAGLE, SELF-SHARPENER, SUBSOIL, AND OTHER HIGHLY-FINISHED PLOWS.}

These are made by the proprietors from patterns of their own peculiar invention; and in the great variety of sizes, forms, and fixtures, are found those adapted to all kinds and conditions of soil, and modes of culture, in the different parts of the Union.

In the construction of the wood part of the plows, they use machinery particularly adapted to that business, which has been patented, and is used only by themselves. 'This forms all plows of the same size precisely alike, and insures a uniform operation. 'They are readily taken apart, and can be put up for distant transportition ; and when any part is needed for repairs, the manufacturers furnish cheaply all such pieces required, which are sure to fit, and the furmer is at once accommodated. The parts are easily attached, and it is not necessary to carry the plow to a distance to be repaired by inexperienced hands.

The timber of which these plows are made, is second-growth white oak, and is so widely and filvorably known as to require no remarks.

'The mould-board, lindside, and point are ground and potished, and coated with blue varnish to prevent rusting, which gives them the appearance of blued stecl. They are thus fitted to use in the most adhesive soils, so that the dirt will not stick and impede their progress; and they are fist taking the place of wrought-iron or steel mould-boards, so much used in the rich lands of the Southern and Western States, as they move equally free, and cost much less.

'The iron of which they are made, is composed of an admixture of several kinds, which produces a metal of far greater strength and durability than the ordinary iron used for the purpose, and it thereby 
endures safely the chilling process which is applied to the point and wing of the share and base of the landside. 'This process insures at least one hundred per cent. more service in those parts so soon worn out in other plows.

The superiority of the Improved Worcester Eagle Plows has been so thoroughly established, and is now so widely known, that it would seem superfluous to dwell upon it. To such, however, as may not be familiar with their great success, it may be proper to mention the astonishing fact that over FOUR HUNDRED PREMIUMS have been awarded to these plows and the plowmen who have used them, by the different Agricultural Societies in the United States and elsewhere, 'They have encountered the strongest competition, but have everywhere been successful. This is owing, not only to their superior workman. ship before mentioned, but also, in a high degree, to the superiority of the mechanical principles upon which they are constructed. The draft, o1 power, required to move these plows in turning a furrow of any required width or depth, is less than any of the plows used in competition with them, as was conclusively shown in a very carefully-conducted trial in Massachusetts, where the dynamometer, (an instrument for measuring the exact amount of power, ) was used, and every precaution was adopted to avoid mistake and insure impartiality. In this trial, it was found that, while the larger sizes of these plows required but $425 \mathrm{lbs}$. to move them, the best three of all others offered in competition required respectively, 450, 487, and 512 lbs. to perfolm the same work. The Committee of Judges in Essex Co., Mass., on Plows and Plowing, who made the most elaborate and perfect investigation of plows ever made in this country, in speaking of the Improved Eagle Plow, to which they unanimously awarded the highest premium, say :- "As nearly as we can ascertain, this plow combines all the good qualities manifested in either of the others, with some peculiar to itself. Our attention was called to the quality of the castings on these plows, their finish and durability. Their appearance is certainly more perfect than we have else. where scen. The process of chilling the points, the entire edge of the share, and flange or base of the landside, give a permanence and durability to the work, that renders it decidedly of a superior character, and we think there is no hazard in saying that the value of the parts thus made is more than doubled by the process."

We have only to add, that the high yet just praise above awarded to these celebrated plows, is fully corroborated by the experience of thousands of practical farmers and planters who have since annually purchased and used them.

Please to take particular notice that we are the EXCLUSIVE AGENTS for the sale of these plows in New York, and any others offered as "Eagle" are COUN'TERFEITS and an inferior article. 
FiAgt, No, 20 .

A four-horse plow, adapted to frce alluvial soils, where wide and deep furrows are desirable, and well calculated for turning under a large grouth of stubble, weeds, or green crops.

\section{Fagle No. 36}

Is a light-sod plow, casy of draught, and particularly adapted for horses, and suitable also for stubble or erossing, the wing of the plow throwing over more than Liagle 1, 2, or 9.

\section{EAGLE: No, 0}

This is the smallest size of the Eagle-Plow. It is suitable for one horse at the North, or two mules at the South. It is of very easy draught, and possesses great merit for a small plow.

\section{Eagle No. 1.-With Wheel and Cutter}

(See Fig. 2.)

[For uses and advantages of Wheel and Cutter, see Remarks on Plowing, pages 6 \& 7 .]

Eagle No. 1 is called at the North a medium-sized Sod or Stubble-Plow, and is easily drawn by a pair of horses or oxen. At the South it is considered a large size, and will generally require three mules to turn a furrow with it, six inches deep and eleven inches wide, although this has often been accomplished by a single pair. It cuts a furrow any required depth from seven to ten inches and from ten to twelve inches wide.

\section{EAGle No. 1.-With Lock-Coulter.}

[For form of Lock-Coulter, see Fig. 4.] This is the same size and shape, and performs the same work as Eagle No. 1 with cutter.

\section{Eagle No. 2.-With Coulter, or Fin-Cutter and Wheel.}

(See Fig. 3.)

A two-horse Sod or Stubble-Plow, of same construction, but one size larger than Eagle No. 1 It cuts a furrow any required depth from eight to twelve inches, and twelve or fourteen inches wide.

EAgle No. 25. With Whed, Cutter, and Draught-Rod.

(See Fig. 2.)

A four-horse Sod or Stubble-plow. It is also admirably adapted for breaking up rough ground and trench-plowing. It is the best plow for covering up a great growth of weeds, stubble, and grass. It cuts a furrow any required depth to twelve inches, or even deeper, and sixteen to eighteen inches wide.

Sivard C A strong threc-horse plow, partienlarly intended for breaking up deep, rough, or stony sward soils. It is larger than Eagle No. 2 .

SwaRd B. A strong four-horse plow of same construction nearly as sward $\mathrm{C}$, but one size larger 


\section{Sward D. For Reclaiming Meadows.}

A strong four-horse plow, same size and form as sward B, with the addition of a wrought lock-coulter as attached to fig. 4. To this plow is affixed, when required, a sharp steel-edged share or point, cutting very wide, and a reversed or drag-cutter for the purpose of plowing and completely turning over the surface of wet meadows, when drained by ditching. A crane or dial-clevis is attached to the end of the beam, which enables the off ox or horse to keep clear of the miry open furrow, so very fatiguing to him, and tread on the unbroken ground, thus making it comparatively easy work for the team, and obviating the great objection to breaking up wet mealows or swampy ground The newly invented dial-clevis and draught-rod, as hefore described, will enable the off horse to tread on solid ground in plowing wet meadows, nearly as well as the crane-clevis. This is an admirable plow for the wet lands on the Mississippi, and for the prairie lands of the West. When the fixtures for meadow plowing are removed, and the original point or share is replaced, the plow is again adapted to the rugged upland soils, thus answering the double purpose of an upland and meadow-plow.

\section{EAGLE SELF-SHARPENING ANID ADJUSTABLE STEEL-POINTED PLOWS.}

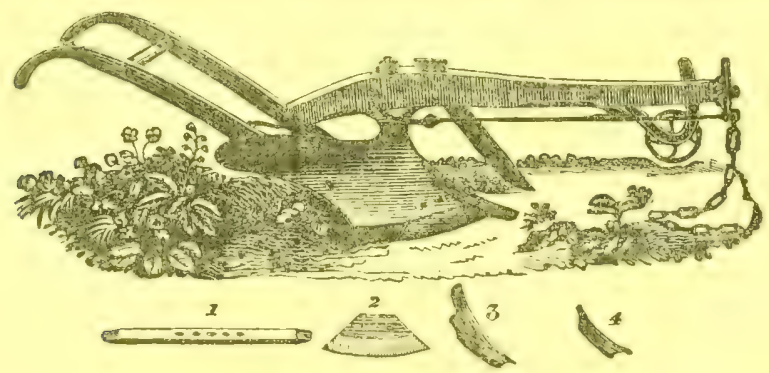

Fig. 5.

These have the same superior form and general construction as the celebrated Eagle-Plows, with the exception that the point and share consist of two pieces, which are made on an improved self-sharpening principle.

The point, as shown detached at No. 1, fig. 5, is simply a bar of wroughtsteel, about twenty inches long, which passes upward into the body of the plow, where it is confined with one bolt. As it becomes shorter, and worn on the under side, it is readily moved forward and the under side turned up, thus always presenting a sharp point of full length and proper shape; when one end is worn off five inches, the other end is placed forward and performs a like service. The wing or share, as shown detached at No. 2, is made of either wrought-iron with steel-edge or of cast-iron, and is also reversible, being used either end forward or either side up.

Both point and share are so very simply constructed, that any blacksmith can replace them at trifling expense, or perpetuate the use of the original by newlaying with steel, as they become worn. 
There is a coulter of cast-iron a little back and above the point, as in fig. $\mathbf{3}$, page 8, and shown detached at No. 3, fig. 5, forming part of a cap, shown detached at No. 4, which protects the shin or forward part of the mould-board. It is confined in its place by the same bol: that confines the point, and is cheap'y replaced when worn. This is much less expensive, and in many kinds of soil quite as serviceable as a wrought coulter or cutter, as shown by fig. 5 They are sold with one or both, or with simply the cap.

These plows are particularly suited to Southern plantations, as the black. smiths can easily repair them

Self-sharpening points and shares have been considered objectionable, inasmuch as they have not possessed sufficient strength, owing to their complicated construction of cast metal; but a single glance at these plows will convince any person, that by constructing the point and share of wrought-steel, they combine strength and durability unsurpassed by any other, and that they are kept in repair at much less trouble and expense.

The point can be used projecting more or less forward, causing the plow to incline more or less into the ground, as different soils may require.

A light one-horse or mule-plow.

$$
\text { Eagle: Self-sharpexer, No. } 1 .
$$

Eagle Self-sharpener, No. 2.

A medium-sized one-horse plow, useful at the North and South.

Eagle Self-sitarpener, No. 3.

A medium-sized two-horse plow, for sod or stubble-land.

Elgle Self-sharpener, No. 4.

A large-sized two-horse plow.

Eagle Self-sharpener, No. 5.

A strong breaking up plow. It is an admirable implement for breaking up deep, stony, or stiff clay soils.

\section{EAGLE LEFT-HAND SELF-SHARPENING PLOWS.}

These are made to turn the furrow-slice to the left instead of the right hand and are constructed upon the same self-sharpening and adjustable steel-pointed principle as described above. They are used in many parts of the West, principally by the German and Dutch farmers. To these are attached, or can be all the different fixtures as to the right-hand plows.

In those sections where three or more horses are sometimes used abreast, the Dravgrit-Rod has a very great additional advantage, as the plowman readily adapts the plow to be drawn either by two or more horses. They are designed to be used with heavy teams in rugged soils, and possess extra strength of timber and mctal.

LEFT-HAND, No. 40.

Is a size suitable to be drawn by two strong horses.

$$
\text { Left-Hann, No. } 41 .
$$

Is of a heavy larger size, and designed to be draw by three or more horkes 


\section{CORN, COTTON, AND RICE-PLOWS, \&C.}

No. 14.-A light single one-horse or mule-plow, designed for carrying a wide furrow in a light or sandy soil, and well adapted to Northern and Southern culture. The mould-board is longer and more curved than other kinds of plows, and works and pulverizes the soil admirably.

No. 15.-A single horse or mule-plow of same construction as above, but one size larger.

No. A 1.-A light one-horse or mule-plow better calculated for a loamy or clayey soil. It is much used among cotton and corn, as well as for furrowing out or drilling.

No. A 2.-A single horse or mule-plow, same construction as the above but one size larger.

No. A 3.-A two-horse stubble-plow-much used at the North for general plowing; and is highly approved for breaking up rice and cotton-lands of the South.

No. B 1.-A large one-horse plow; is frequently used with two horses, and for the same purposes as No. A 3.

No. B 2.-A small two-horse plow, same as the above, but one size larger. It is much used both in the North and South.

DAvis 6 lNch.-A light one horse or mule-plow, particularly designed for the South.

DAvis 7 INch.-Of nearly the same construction, but a size larger than the above.

\section{Rice Trenching-Plow.}

This plow is made from a pattern furnished by an eminent Southern planter In trenching a field for the rice-crop, it will do the work of many hands with hoes, and will be found a great labor-saving implement for this purpose. It is an excellent implement, also, for opening drills for corn or cotton, and for various root-crops.

Ridging or Double Mould-Board Plows.

No. 1 -Double-Munld Board.

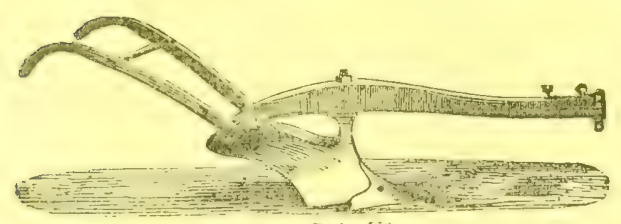

Fig. 6. - Side View.

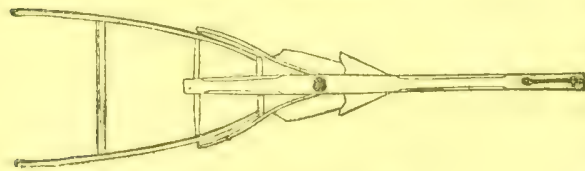

FIG. 7.-Top Viero.

A light one-horse plow, used for opening drills to plant potatoes, corn, \&c. In plowing out between narrow rows, it throws the dirt both ways to the plant, and thus does the work of two plows. It is also very useful in digging potatoes. It is a very convenient implement for various kinds of work, ditch. ing, \&c., and should always be kept on the farm. 
No. 2 Dovble Moum-Board. - Of same construction and use as the above, but one size larger. This is also used in furrowing for planting cane, and making light ditches. It has an extra point made, of an additional width, for the purpose of digging potatoes.

The Funk, - or Double-Expanding Mould-Board Plow, for Planting Sugarcane.-This is a plow recently made, expressly for the use of sugar-planters, by which a furrow is made ten to twelve inches wide, and four to five inches deep.

\section{Paring-Plow.}

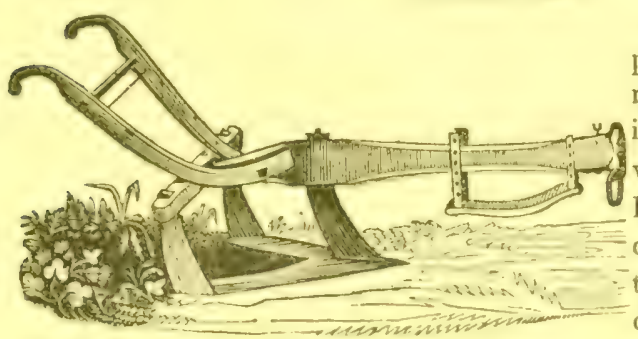

FIG. 8 .

Fig. 8 is a plow used for paring turf-lands preparatory to burning The share is thin and llat, made of wroughtit-iron, steel-edged. It has a lock-coulter in the centre, and short coulters on the outside edge of each wing of the share, cutting the turf as it moves along into two strips about one foot wide, and as deep as may be required.

After the turf is pared off in strips, the hands follow with sharp spades and cut it into suitable leugths, say of two or three feet. These pieces are then thrown into heaps, and after drying, they are burned, and the ashes sprea broad-cast on the lands. Paring and burning is a very ameliorating process for stiff, clayey soils; it changes their mechanical texture, and renders them friable and suitable for cultivation. Light sandy soils should not be burnt.

Side-Hill or Swivet-Plows.

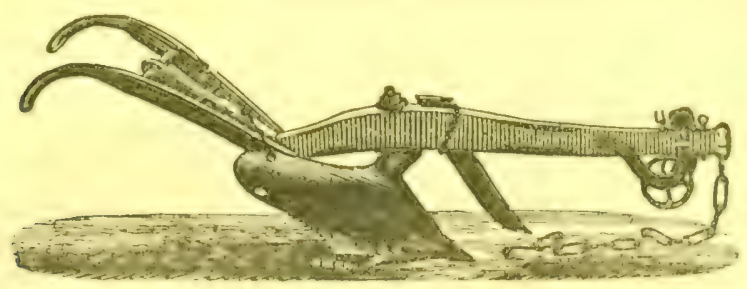

Fic. 9.

Of these there are five different sizes. They are so constructed that the mould-board can be instantly changed from one side to the other, which enables the operator to perform the work horizontally upon side-hills, going back and forth on the same side, and turning all the furrow-slices with great accuracy downward. 'They are much liked at the South; for, by this system of turning and laying the soil, it is prevented from being washed into those deep gullies so destructive to the general face of the country. They are $\mathrm{em}-$ nloyed, and by many are much approved, for level plowing, as this leaves the 
field without any centre-dead or finishing furrow; nor does it make banks or ridges by turning two furrows towards each other. When thus used they save much labor, by aliowing the team to turn short about at the end of the furrows, instead of obliging it to travel across the wide ends of each land in the field. They are useful for plowing down the banks of ditches, as they carefully turn the furrows from the ditch by carrying the earth upon the level ground.

\section{No. 0.-Side-HiLl.}

A light one-horse or mule-plow, more particularly designed for horizontal plowing at the South.

\section{No. A 1.-Side-Hill.}

A light or medium-sized two-horse sod or stubble-plow.

$$
\text { No. A 2.-Side-Hill. }
$$

A large two-horse plow-is sometimes used with three or four horses, according to the nature of the soil.

\section{No. A 3 -Side-HiLL.}

A large four or six-horse plow, made very strong. It is suited for very heavy farm and road-work.

\section{No. A 4.-Side-HiLL.}

A heavy road-plow. It is made very strong, and is especially designed for the roughest road-work.

With wheel and cutter, the medium sizes are highly approved for turning over mowing land for the purpose of re-seeding in the autumn, as with tho cutter they lay the furrow-slice flat, and with great uniformity, avoiding the centre and bank furrows, and leaving the land the same general level as befor plowing.

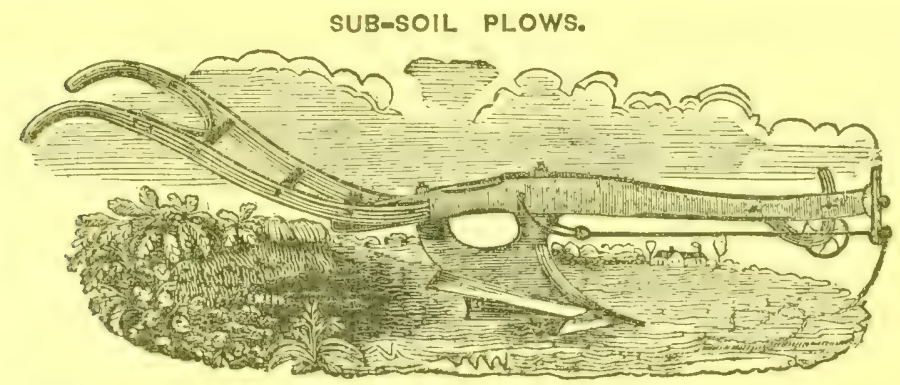

FIG. 10.

There are iour sizes of these, all of which are constructed on the principle of the most approved Scotch Sub-soil Plow, one of which was imported from Scotland for the purpose of furnishing the most approved model. By modifymg and simplifying its construction, at the same time making some important 
iaprovements, the farmers and planters of this country are now supplied with plows lighter than the Scotch Plow, yet better adapted to our soils, and of equal capacity, at a much less price

They are now much used in different sections of the United States, and with great satisfaction, and the demand for them is constantly and rapidly increasing. These plows are used by following directly after the team which turns up the surface-soil, and in the same furrow. This is of great advantage to the crops, both in dry and wet land. In the former, the sub-soil being deeply broken up, and well pulverized, the moisture is retained much longer than it otherwise would be, and the roots of plants can descend much lower and wider for their fod; while in the latter, the excess of moisture filters below, and is readily carried off. 'They, however, require that the earth below them be sufficiently porous to admit of the escape of an excess of moisture, or their beneficial use is not felt till the land is well drained.

\section{No. 0.-SUB-SOIL.}

This is a one-horse plow at the North, and is used with one or two mules at the South. It will break and pulverize the sub-soil any required depth to six inches below the previously-turned furrow.

$$
\text { No. 1.-Sub-soil. }
$$

Is a medium size, and is mostly used in ordinary clear soils, with two or three, and somethnes four horses. It will run twelve inches deep.

\section{No. 2.-SuB-SoIL.}

A large plow. It will break and pulverize the soil any required depth to eighteen inches.

$$
\text { No. 3.-SuB-Sort. }
$$

Is about the same size as No. 2, but is used with either a single or double wing point, and with an inclined plane to raise the soil upon one or both ends at the same time.

We recommend the use of the draught-rod on all sizes of the sub-soil plows, as we consider it almost indispensable in enabling the off animal to walk on the solid ground, and the plow to work easily in the surface-soil nurrow

\section{NEW YORK AND OTHER PLOWS.}

As many farmers and planters require plows of similar construction to some of the preceding, and at a cheaper price, the following sizes and numbers have been extensively manufactured by ourselves, for this purpose. They correspond in size, weight, and form with the preceding, and are made with equally gond materials, but they are not so highly tinishet, nor are the irons ground and polished.

New York No. A 1.-A light one-horse or mule-plow, does well for 'oamy soils and clay.

New York No. A 2.-A size larger than the above, and suited for the same kind of soils. 
New Yor ז No. 14-A light one-horse or mule-plow, for light sandy lands

New York No. 15.-A size larger than the above, and intended for the Eame kind of soils.

New York No. B 2,-A light two-horse plow for general work.

New Yonk Eagle No, 1.-A medium two-horse plow.

New York Éagle No. 2.-A large two-horse plow, for various work and moils.

\begin{tabular}{|c|c|c|}
\hline \multicolumn{2}{|c|}{ One-Horse Corn-Plows.-No. 10} & No. 1, J. M. \& Co.'s \\
\hline No 60 & " 11 . & "s 2 , " " \\
\hline " 80 & “ 12. & " 18, M. \& H. \\
\hline " 81 & Corn. & "19, " " \\
\hline
\end{tabular}

Cabeage Plow. Seed.

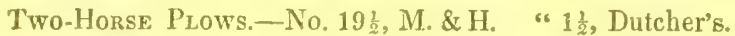

$\begin{array}{llll}\text { " } 20, & \text { " } & \text { " }, ~ & \text { " } \\ \text { " } 13, & \text { " } 3, \text { J. M. \& Co.'s } \\ \text { " } 13 \frac{1}{4}, & & \text { " } 4,\end{array}$

Bergen Plows--For two-horse and general work.

Castings for the New York, Eagle, Minor and Horton's, Mayher \& Co.'s Freeborn and Hitchcock's, Dutcher's, and other plows.

\section{Three-Share Plow.}

This machine spreads two feet six inches wide, with three shares; but if made with four shares it would be proportionably wider. It is used for plow ing in wheat, rye, and other grain, after sowing; and taking so many furrows at a time, it gets over the ground very rapidly. Three to five acres per day may be covered with it. Grain plowed in is not so likely to winter-kill. Tho ground should not be harrowed in the fall, but be left rough. In the spring it may be harrowed and rolled. It is drawn bv two horses. One or two wheels are now placed at the end of the beam, which makes it run easier and Fteadier, and enables the plowman to gauge the furrow-slices to an exact depth. It has been supposed that this plow would do well for the South to work out between the corn, cotton, and sugar-cane rows; but we believe it is too heavy for such work with single mules.

Scotch Plows.-These are made of iron throughout, and will be importer to order. They cost from $\$ 25$ to $\$ 40$ each.

\section{SOUTHERN PLOWS.}

We have recently constructed a series of plows, of various numbers and sizes, on the same principle as the above, with higher or longer standards. This sets the beam from two and a half to four inches higher than in the same sizes of Northern plows. Thus constructed they do not clog in the foul, moist, and weedy lands, but clear themselves perfectly, and move along with great ease and rapidity. 
In addit on to the fore-named we have various other plows suited to every lo. cality in North and South America, and the West India Islands; among which are steel-points and shares, steel and wrought-iron mould-boards. From out facilities for manufacturing these, and implements of almost every description for the farm, plantation, and garden, can be male to order at short notice.

\section{CEIMTE AMOR.}

The Cultivator is a great labor-saving implement, for stirring the earth between the rows of corn and other crops. It is also well adapted for mixing manures in the soil, and pulverizing it after plowing. It leaves the soil much lighter and in better condition to receive the seed than when the harrow only is used. It is useful for covering grain sown broad-cast, and buries it at a more suitable and uniform depth than the plow, and in one-fourth the time; and much more perfectly than the harrow.

There are various forms of teeth. Some enter and stir the soil deep; others are broad and flat, to skim the surface and cut up the weeds, while others are made with scarifiers or narrow teeth; and as all are made to fit the same size and form of mortice, by purchasing different forms of teeth, the farmer can use them in the same frame-work.

They are made to expand and contract, to conform to the width of rows, \&c. Some are made having the hindmost teeth so formed as to turn the earth towards the plants, and by shifting them from side to side, turn it from them, as may be required.

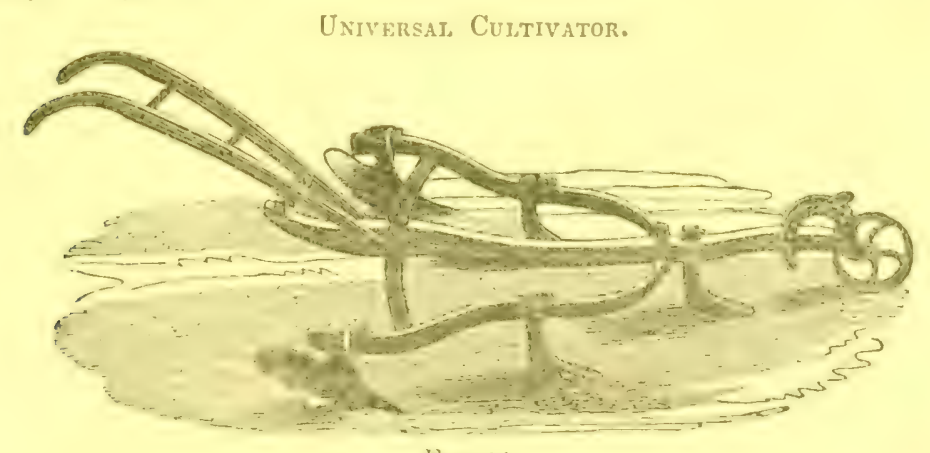

Fiti. 11 .

Tig. 11, sepresents a cultivator recently constructed. It is made longer than common cultivators, and is all of iron except the centre-beam and handles; and the side-beams being of wrought-iron so curved, that as they are explanded or contracted, by lonsening the iron-liey that confines the tooth in its place, they are each moved forward or back to a point that will again cause thern to work parallel with the centre-beam and at equal distances from each other. To these are fitted several sets of different formed teeth and scarifiers, of wrought and cast-iron. 'They are sold with one or more sets.

There is also one pair of teeth calculated to work in the rear, revresented by 
Fig. 11, which may be used instead of the common teeth. They are in form like small plows, turning the furrows in opposite directions, and fitting alike both side-beams; by changing they may be so placed as to turn the furrows to or from the centre, or rows of vegetables. If the forward teeth are used at the same time, they finely pulverize the soil, and if the plows are set towards each other, they form a light bed in which to plant any kind of seeds. Any form of wrought teeth may be attached to them by blacksmiths, as the manner of fitting them to the beams is very simple and easy. This cultivator is made to expand from two to five feet.

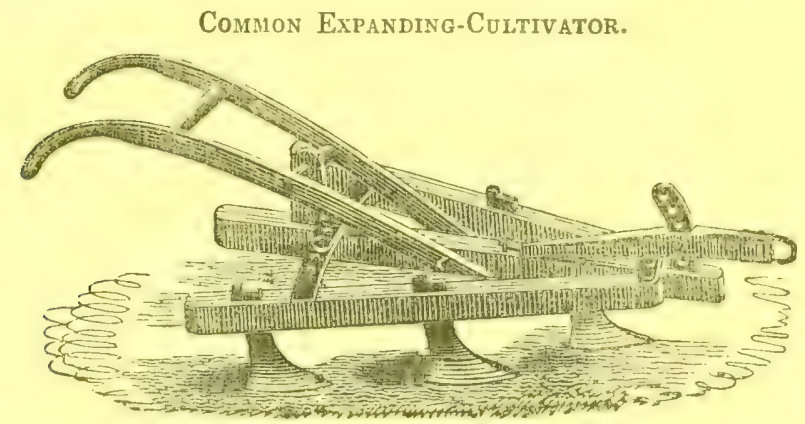

FIG. 12.

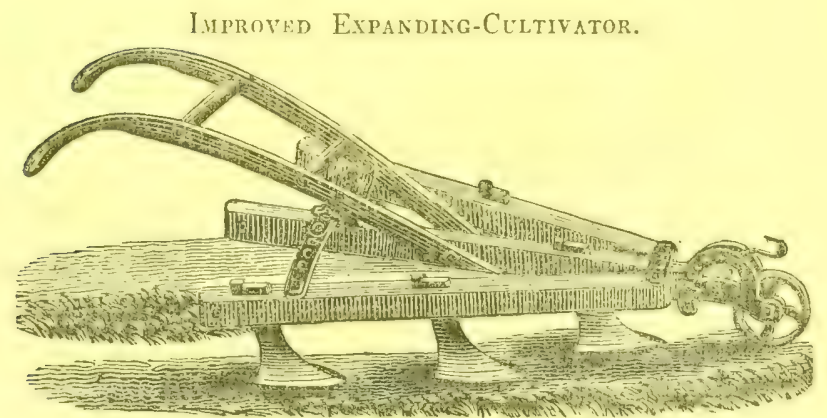

FIG. 13.

The wheel (Fig. 13.) is a late invention, and is found to be a great improve ment, as it causes it to move steadily and easily, and assists the operator in getting around the ends of rows and obstructions in the field.

Langdon's Cultivator or Horse-Plow, - This, in reality, is a plow with a light, wide, flat share, sharp at the edges. and coulters on the mould-board. It is used for rumning between the rows of different crops, to cut up the weeds and loosen the soil. It is also an excellent implement for digging potatoes. The shares can be detached and wings added, which converts it into a double mouldboard plow. It is only recommended for light soils free from stones. 


\section{Cottox-Sweep Cultivator.}

This implement is made expressly for the purpose of taking the place of the cotton-sweep, besides doing much additional work. It is made with very sharp steel teeth, so arranged as to cut up all grass and weeds, at the same time finely pulverizing the soil. It can be so expanded or contracted, as to suit every wilth of row. It works so lightly that one mule can draw it.

Hand-Culativator.

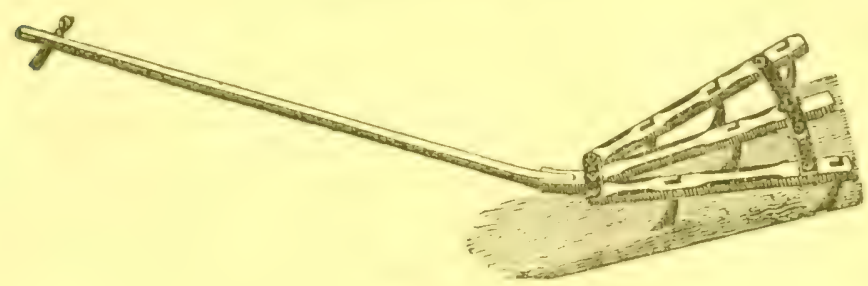

FIs. 14

This cultivator is made entirely of iron except the handle, and expands from ten to eighteen inches. It is a very useful implement in garden-culture, and is often used in fields, among rows of carrots, beets, \&c. It cuts up, and leaves the weeds exposed, and stirs the earth very thoroughly.

\section{ROILERS.}

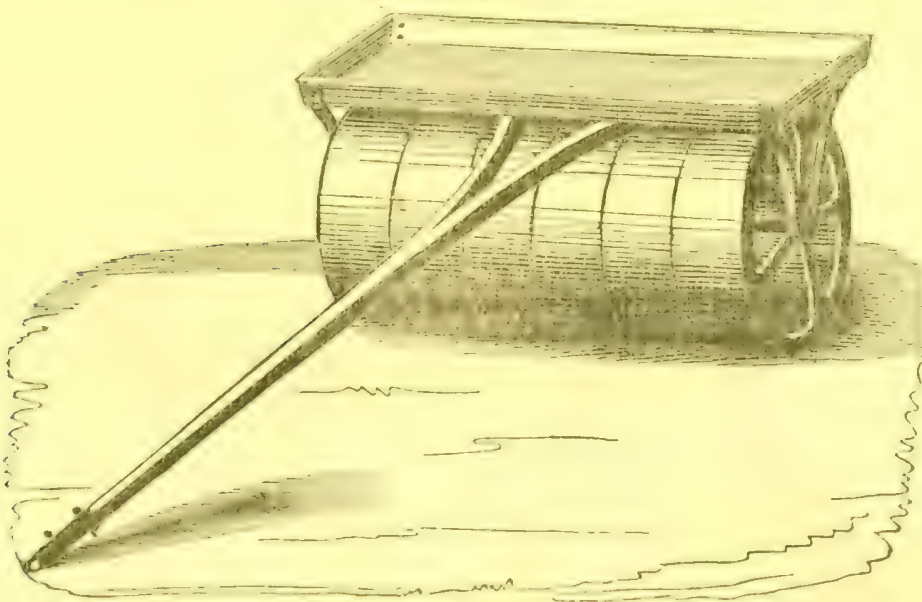

IIT. 15.

'These are important implements, and are fast coming into general nse. They crush all sods and lumps that remain on the top of the ground after the harrow has passed, and force down small stones level with the surface. 'They render' the ficld smooth for the crudle, scythe, and rake, press the earth close about the seed, and secure a more sure and quick germination.

On light and sandy lands they are invaluable, and in all cases their use has greatly increased the product. Much benefit is undoubtedly found in 
compressing the surface of such light soils, by preventing the escape of those gases from the manure so essential to vegetation, and which are so rapidly extracted by the sun and winds.

Great advantage is gained by rolling early in the spring, while the ground is yet soft. Clay-lands, by heaving, pull to pieces and displace the roots of grain and grasses sown the previous autumn, and the heavy roller presses the roots and earth together to their proper position, when vegetation goes on again, and thus, in a measure, prevents what is termed winter-killing. They are variously made of wood, stone, and iron. Those of iron are most desirable, being less liable to break than stone, and are not subject to decay like wood.

Fig. 15 represents the most approved kind, constructed wholly of iron except the tongue and box, which are of wood. These rollers are made either 18 or 24 inches in diameter, in separate sections, each one foot long, placed on a wrought-iron arbor on which they turn independently of each other, thus turning without much friction and leaving the ground smooth. They are generally used with three to six sections. If four only are required, thills or shafts may be substituted for the tongue, and drawn by one horse, or both may be used alternately according to the team. The box is attached to receive stones, \&c., picked up on the field, and for giving weight to the roller according to the work required. They are made of all sizes and weights, so as to be drawn by hand or a team.

\section{IIA 30 W}

Of these there are many kinds. Of the common triangular form, we make various sizes, from the light one-horse up to the large four-horse harrows.

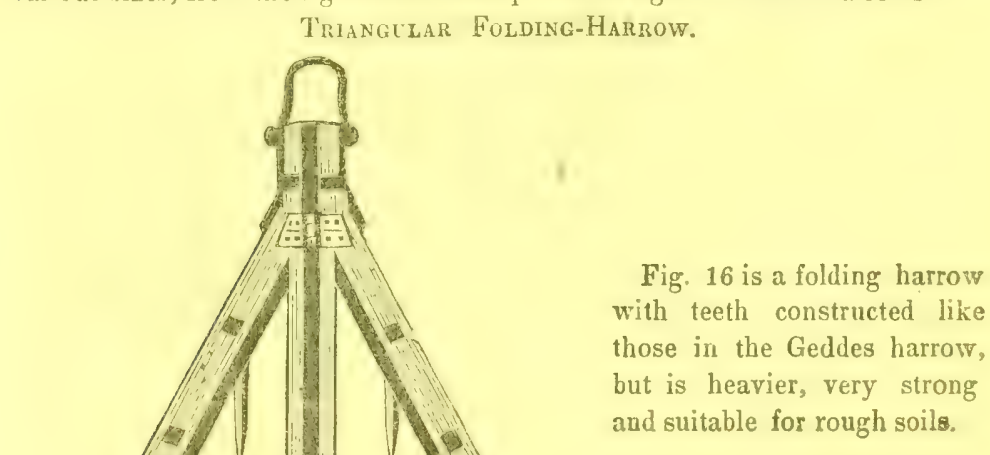


Scotch Harrow.

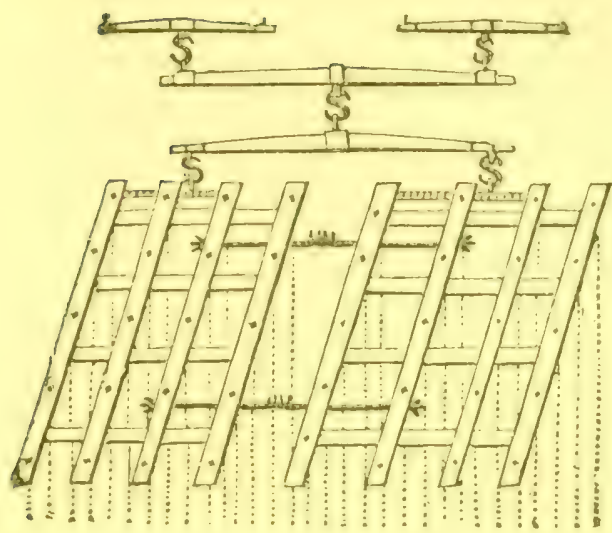

Fig. 17 represents the Scotch harrow, which may be used single or double.

FIG. 17.

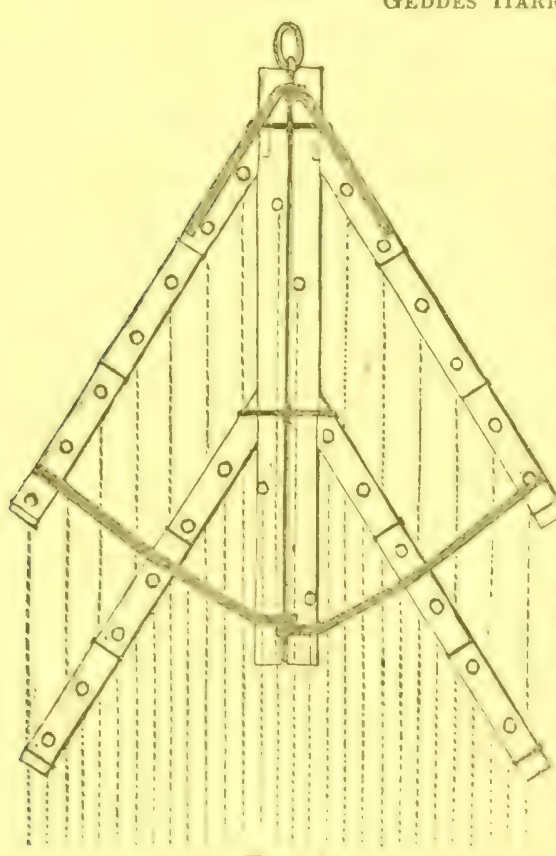

Fia. 18.

Fig. 18 is the Geddes folding. harrow, which is generally esteemed the best. Some of the larger sizes are so constructed, that the front and rear parts can be detached, forming two single harrows, which can be used se. parately when desired. The two side-frames are joined together by hinges in such a way, that the harrow works the surface of uneven lands quite equally; and when one-half is folded over upon the other, it is easily transported about the farm. The teeth are made of the best Srredish iron, steel-pointed, and the upper end is formed to fit a inortice made tapering from the lower to the upper side of the timber, with a screw upon the upper end of the teeth, and are made fast by nuts being screwed close down upon iron-washers, which prevents all liability of the tecth to become loose and drop out, as in most kinds of harrows. The Geddes harrow is superior to the square harrow, as it draws from one 
point, with a regular, not a or straggling motion, and of course is easier ior the team. Fither part is easily lifted when in motion, to let off any trash that may have collected among the teeth.

Sufficient attention is not praid to harrowing. It is the next most important operation after plowing. The harrow should run from four to six inches deep, cutting up all the lumps, and leaving the ground in a finely pulverized state. These harrows have from fourteen to thirty teeth.

\section{SFED-5OWTER, \&c.}

Improven Brush Seed-Sower

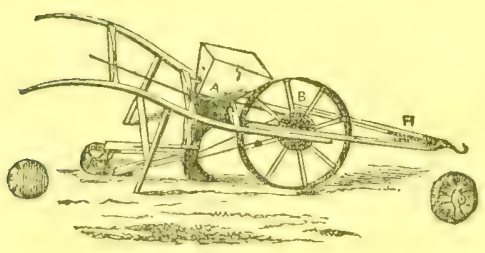

Fig, 19.

This machine, with all its essential parts, has been lang in use in this country and in England, and is found to be the only one that plants all the variously formed small seeds rapid. ly and with precision. The cut represents the machine with the hopper and appafatus for sowing the small garden-seeds, such as onions, turnips, carrots, parsnips, beets, \&c.; and also millet and other small grains in drills. It it easily arranged to plant a greater or less quantity, as may be required.

By substituting another hopper, which fits in the place of the present one when removed, and with different dropping fixtures, peas, beans, corn, \&c., may be planted in drills, or in hills from 6 inches to two feet apart. It is but a moment's work to exchange one for the other, and in this, the quantity of seed planted is easily regulated.

The operator moves forward as with a wheel-barrow, when the drill is opened, and the seed is deposited, covered, and the soil compressed at a single operation. An acre with rows two feet apart, is easily sown in three hours. Directions for using, accompany each machine.

\section{Bachelder's Corn-Pianter.}

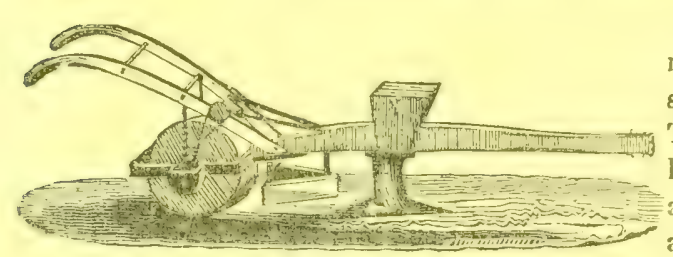

Fig. 20.

This is one of the best machines we have yet seen for planting corn. The seed is put into the hopper above the beam, and as the horse moves along, the share below opens the furrow; the corn is then dropped by arms moving horizontally. These arms have holes that can be altered to a proper size for receiving any required number of grains, and as they pass in and out of the hopper, the holes are filled with the seed, 
which is dropped into a tube conducting it to the bottom of the drill made by the share, that is so formed that it passes under the surface at any required depth, where the grain is deposited without turning over the earth. $\Lambda$ triangalar iron follows to remove all lumps and stones, and a roller to compress the earth over the seed. The dropping of the seed is always visible to the operator, and thus ensures his work being perfectly done. The arms are made to drop the corn nearer or further apart by different-sized wheels fastened on the crank, moving the arms quicker or slower as required. 'The machine requires a small horse or mule to draw it, and with a boy to tend and drive, will plant from eight to ten acres prer day, according to the width of the rows, and at any required distance apart.

\section{Horse-Dril..}

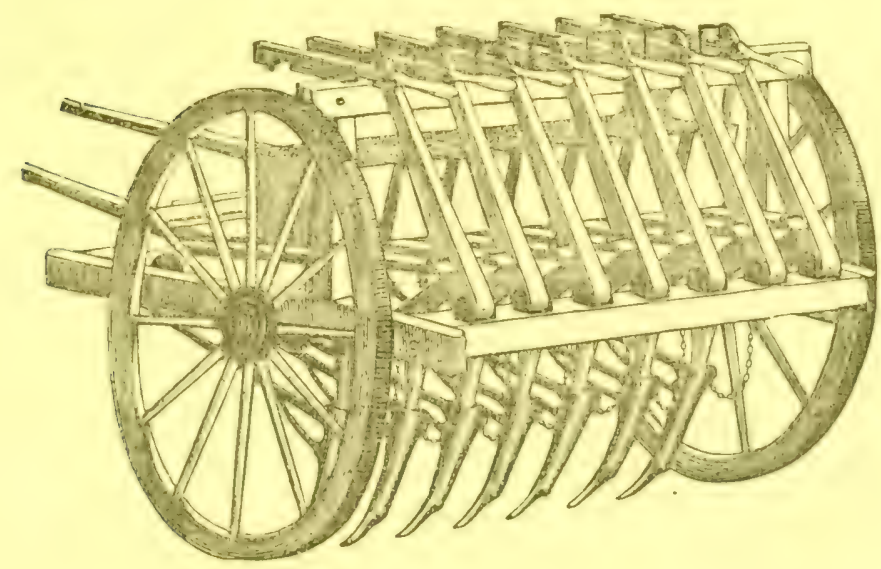

FIG. 21.

This machine will plant wheat, rye, Indian corn, oats, peas, beans, rutabagas, \&c., Stc.; and can be regulated to drop any required quantity on an acre.

The drills can be thrown in or out of gear separately, so as to plant a field of any shape without seeding any part twice. They are so arranged as to operate equally well on all kinds of land-hilly and rough, as well as level and smooth. A man with two horses, can put in from 10 to 12 acres with wheat in a day; and with one horse, he can plant 20 acres with corn per day.

\section{Cotton Seed-Planter.}

Both the corn-planter and horse-drill above described, are easily adapted to soiring cotton-sect, and can be made to do the work of six or eight bands, and much more perfectly than can be ủone by them. 


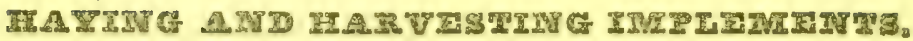

\section{SNaTh and SCythe.}

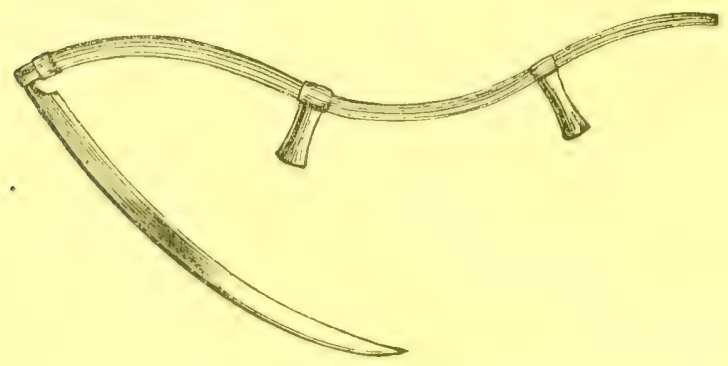

Fig. 22.

A great variety of snaths from different makers and of various qualities, and prices, with and without scythes attached, and some very strong, with two heel rings, for bushes.

Grass, Lawn, Grain, and Bramble or Bush-Scythes.

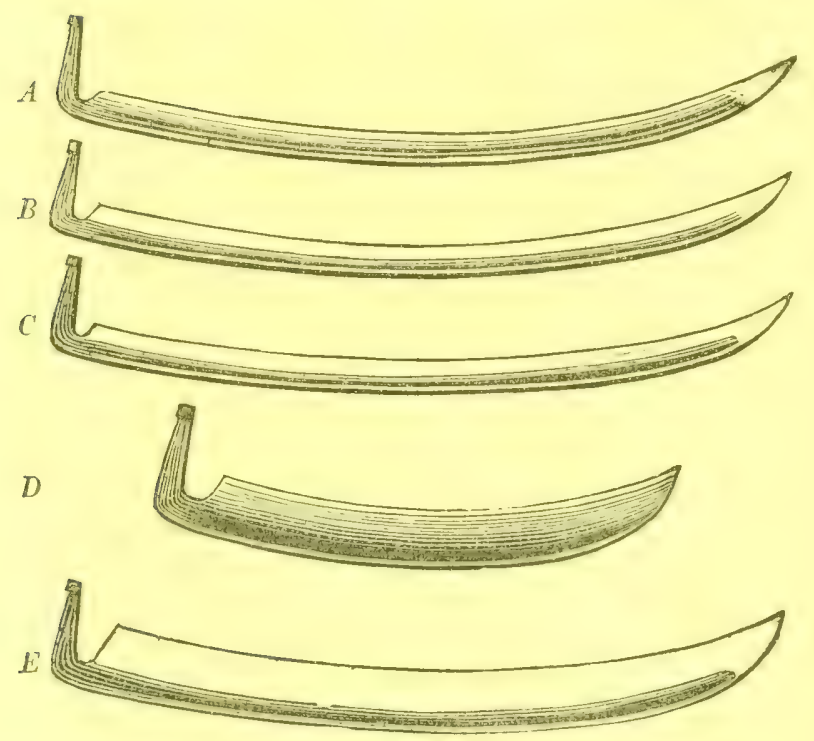

FIG. 23.

The above figures represent the most approved scythes in the market. They are made of the best cast and German dotble-refined steel, with a double and single-ribbed back, also plain ditto. 
Fig. 24. Revolving Hatr-Rake.

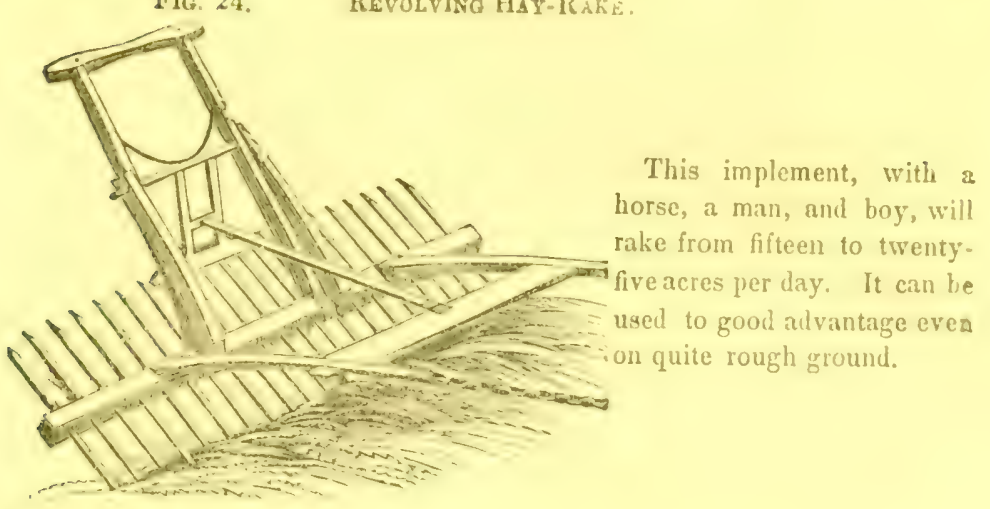

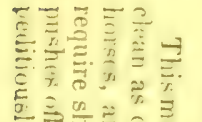

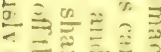

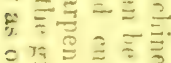

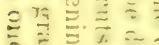

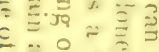

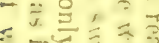

$-74$

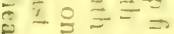

울 $\vec{x}=\overrightarrow{\overrightarrow{0}}$

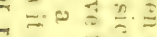

$\vec{F}-\overrightarrow{2}+2$

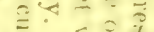

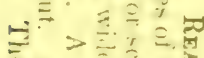

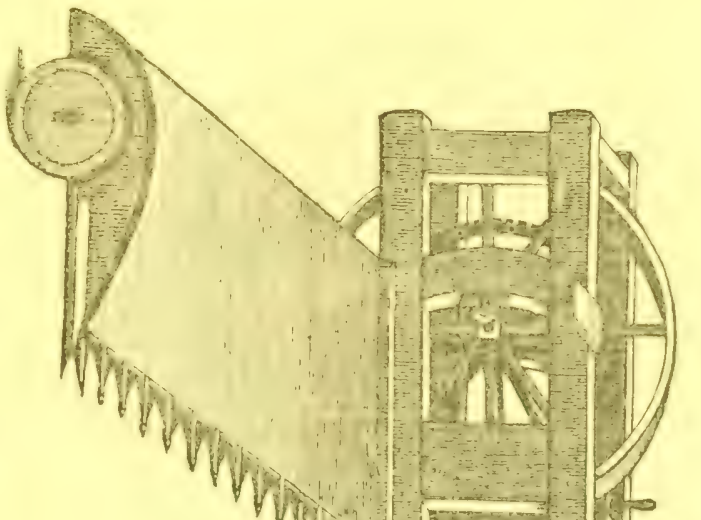

政 $=3$

$\overline{2}$

然照

를. $\vec{E}=$

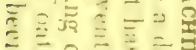

욱

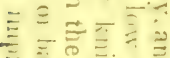

产每:

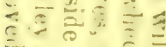

$\therefore 0=0$

$\vec{E} \triangleq$

두을

ह $₹-20$

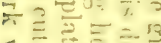

$=\frac{4}{5} 5$

늘

$5 \equiv 3=2$

$\equiv \equiv$

$=\div$

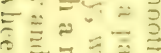

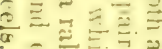

ชอ

This implement, with a horse, a man, and boy, will rake from fifteen to twenty. on quite rough ground. 


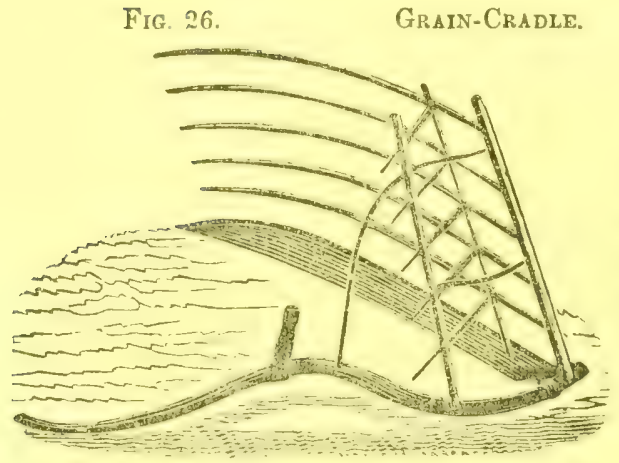

Railuay Herse-Power and Thrasher.

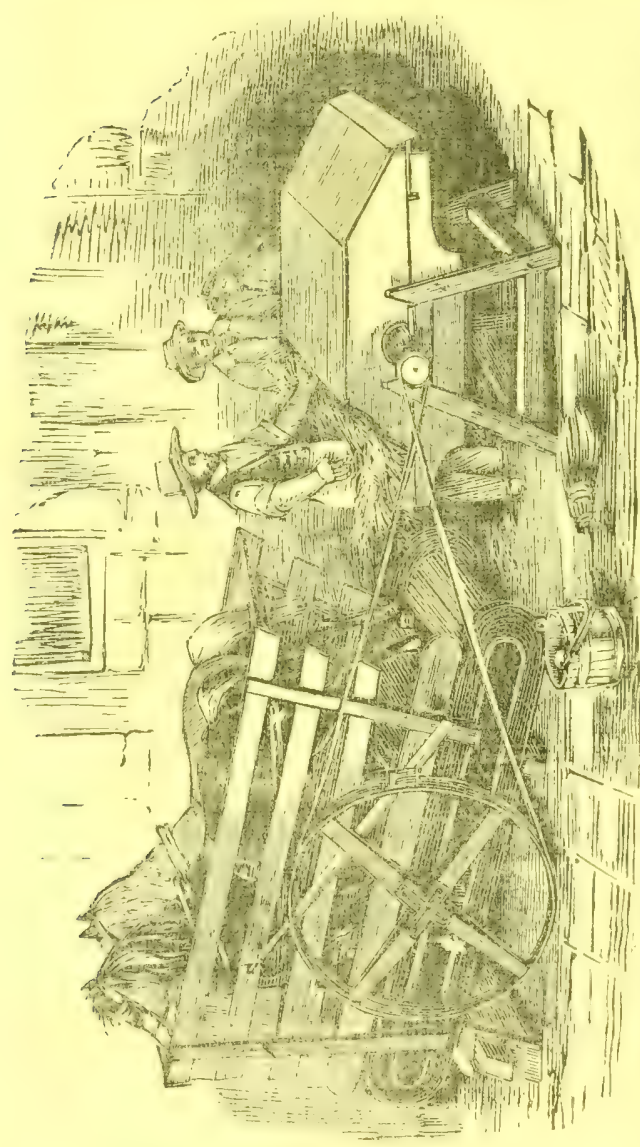

The annexed is of the latest and most approved make, with a superior scythe.

F1G. 27.

The machine, as delineated in fig. 28 , is adaptec to the use of one horse, which, with the aid of two men and a boy, can thrash at the rate of seventy-five to one hundred bushels of wheat, or one hundred to one hundred and fifty bushis of nats, in a day. If only a single horse be used, a hinge should be made "very two or three hours, as it is ratiguing to the animal working it. The machine can readily be fitted for working two horses ilbreast, by increasing the width of the rotary platform as in fig. 27, on which they stand, ant increasing the length of the main shait. The simple contriv. ance called the shaker or separutor, which is attached to the thrasher, saves much labor in winnowing the grain, besides leaving it entirely free from straw. 


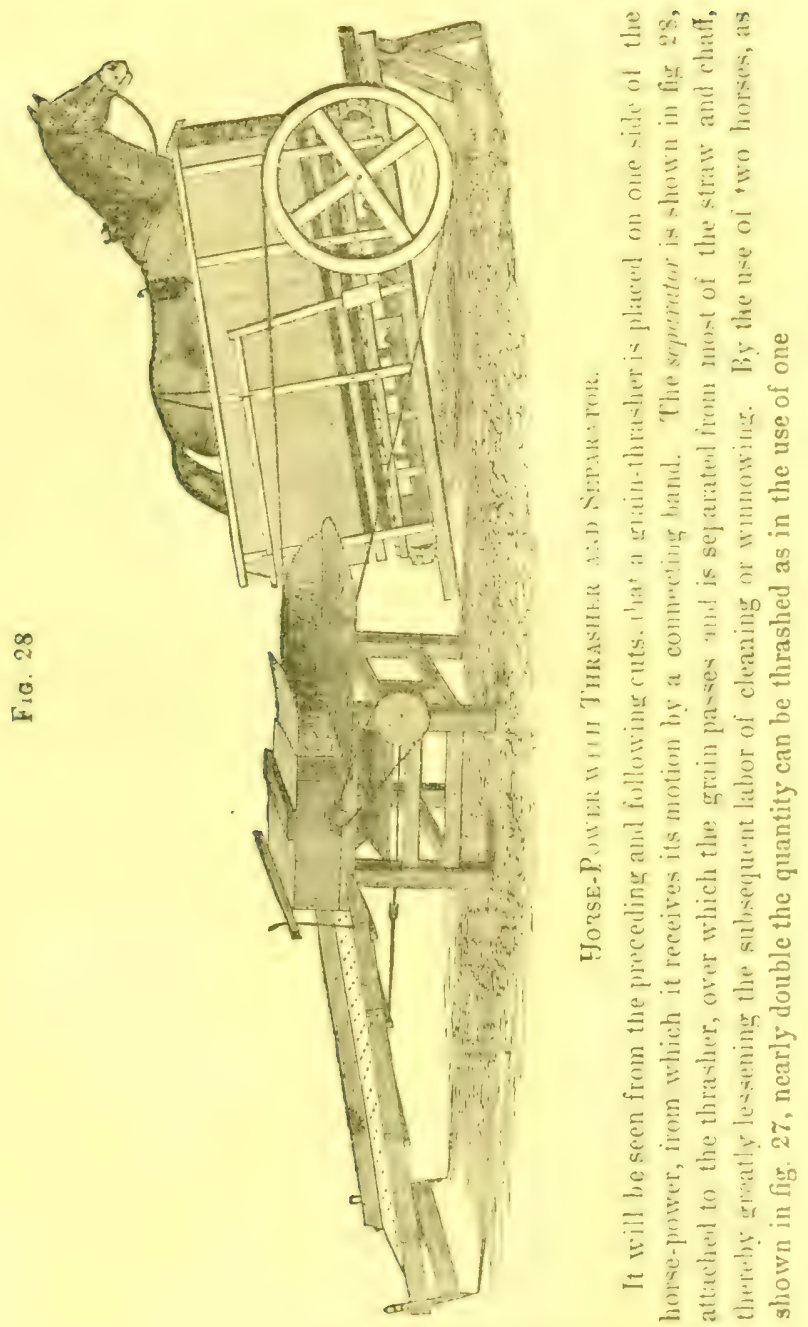

The above and precening cuts also illustrate the railroad or inclined plane Horse-power.

\section{Rice-Thrasirens.}

A complete thrasher for rice is an expensive machine, and will clean several hundred bushels per day; but they are too expensive except for large rice plan tations. The small, cheap grain thrashers, are used with economy and advantage, where only a small quantity of rice is raised. The above and several other kinds of grain thrashers are frequently used for this purpose. 


\section{F.XNMG-MILL.}

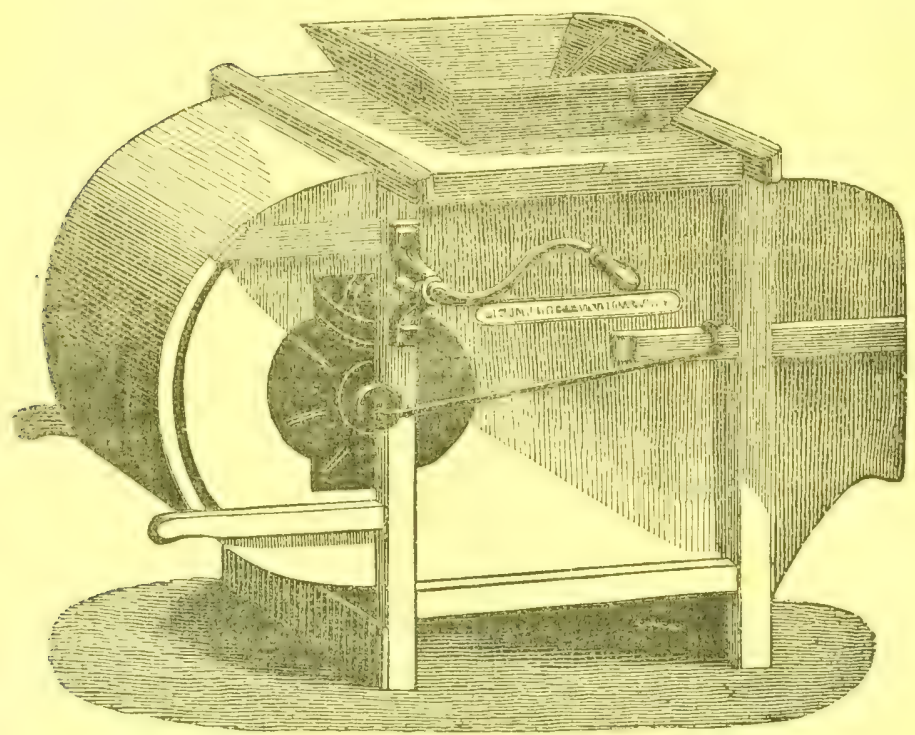

FIG. 29.

Considering the simplicity of its construction, and complete efficiency in all ats operations, we think the ahove fan-mill is the best in use. It has taken thofirst premiums for three successive years at the State Agricultural Society shows, and various county fairs.

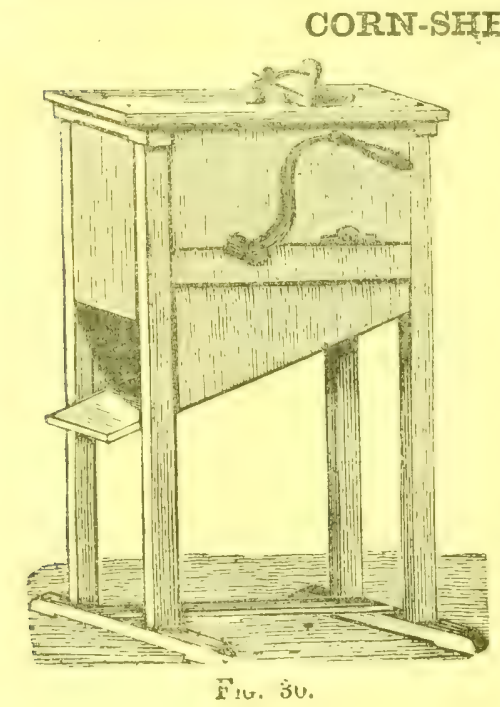

These are of various patterns and prices. That in most common use is upon the same principle as Fig. 30 . Some, like the cut, are made with wooden frames, and some with iron. The first are preferable, as any one can repair them when broken, and the grain does not $\mathrm{fly}$, or scatter, as it is shelled, the sheling plate being encased with wood, as denoted in the adjoining cut. They will shell from 100 to 150 bushels per day, when operated by one hand. 
SMITH'S CORN-SHELLER.

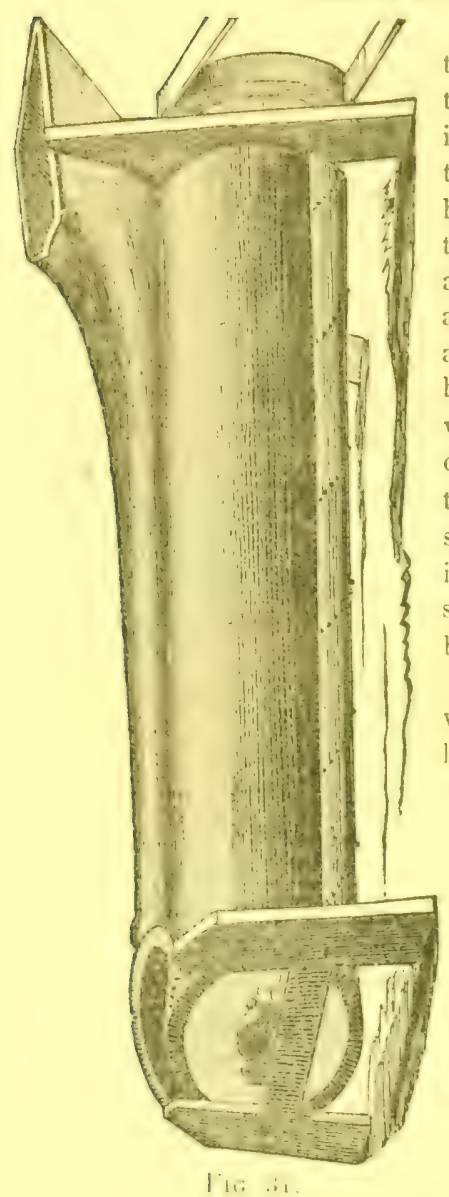

This machine consists of a horizontal toothed cylinder, six feet long, and one font two inches in diameter. The ears of corn, in the operation, are confined to a part of the upper and rising side of this cylinder, by means of a cast-iron concave extending the whole length of the machine; and being admitted into the machine at one end, they are driven through, and the cobs discharged at the opposite end, while the grain falls below the cylinder. The operation is governed by elevating or depressing the discharge end, which causes the machine to throw out the cobs faster or slower; thus seruring to the operator the power of finishing his work. This machine is capable of shelling thoroughly one hundred and fifty bushels of ears of corn per hour.

We have several other corn-shellers of varions capacities, both to turn by hand or larger power.

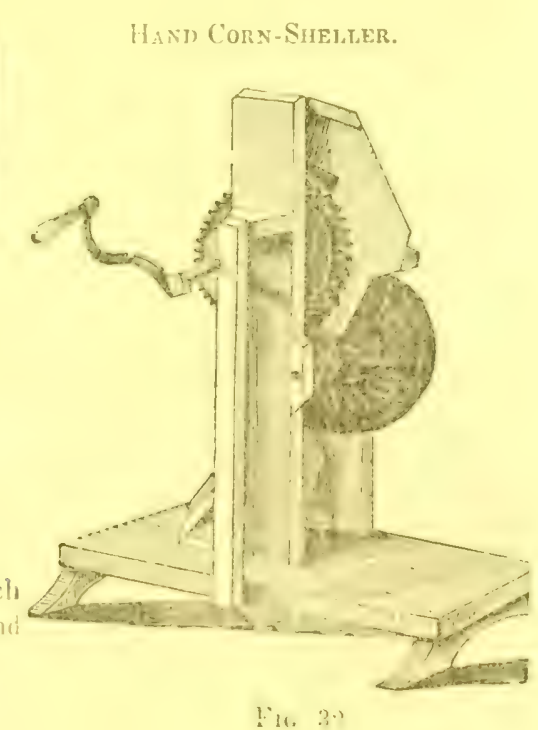

This is a kind of sheller much used, and is a very efticient hant machine. 


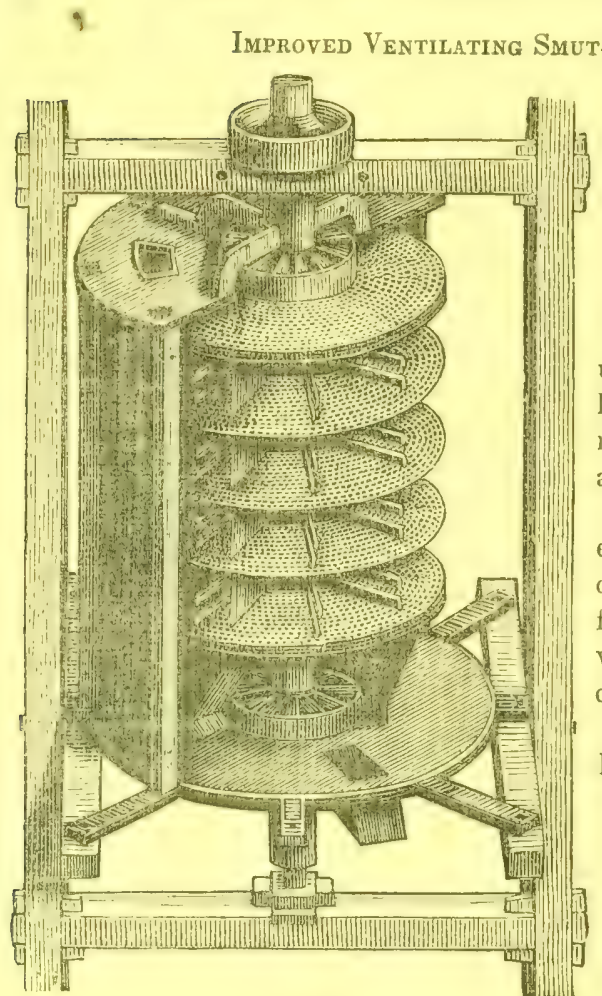

This machine has been in use since 1838. Some of thein have run seven years without repair, and work in all respects as well as when first put up.

These machines are warranted by the inventor to excel al! others in use, and to give perfect satisfaction. The prices vary, according to size, capacity, or fixtures attached.

We have various other kinds and sizes.

FIG. 33.

BARK-MILL, AND CORN AND COB-CRUSHERS.

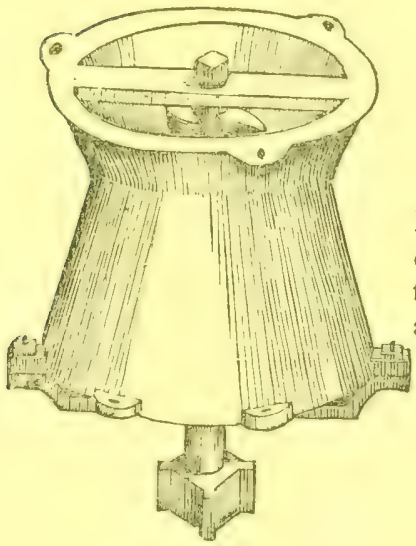

BARK-MIIIL.

The Bark-Mill, fig. 34, is much used at the North and West for the purpose of cracking or crushing the corn and cob together, preparatory to grinding between mill stones. These are made of various sizes.

$F_{1 G} 34$ 


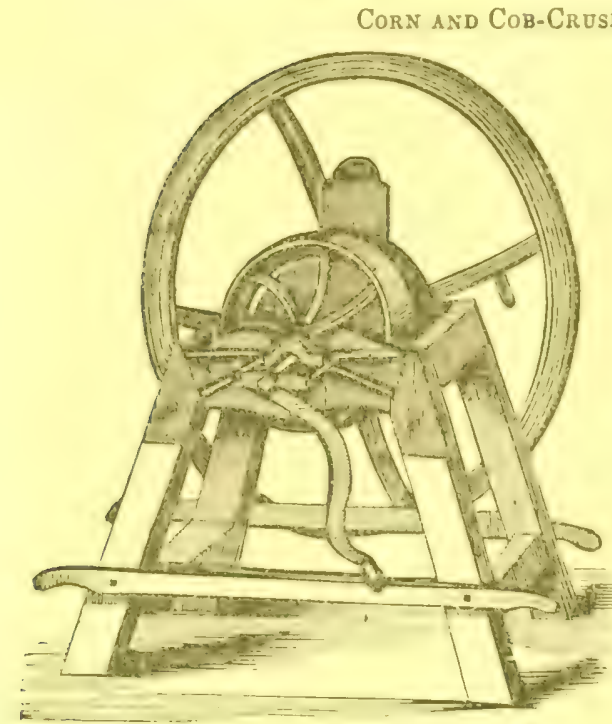

This machine is well adapted for plantation use; the construction is very simple, compact, and not easily put out of order. The grinding plates are made of the hardest composition metal, which will last from two to three years After they are worn smooth, new plates may be substituted without difficulty. A strong spiral knife is attached to the axle, which cuts the cob in small pieces preparatory to entering the plates.

\section{FIG. 35.}

\section{GRAIN, COFFEE, AND SPICE-MILLS.}

HaNd AND HoRse Grain-MILL.

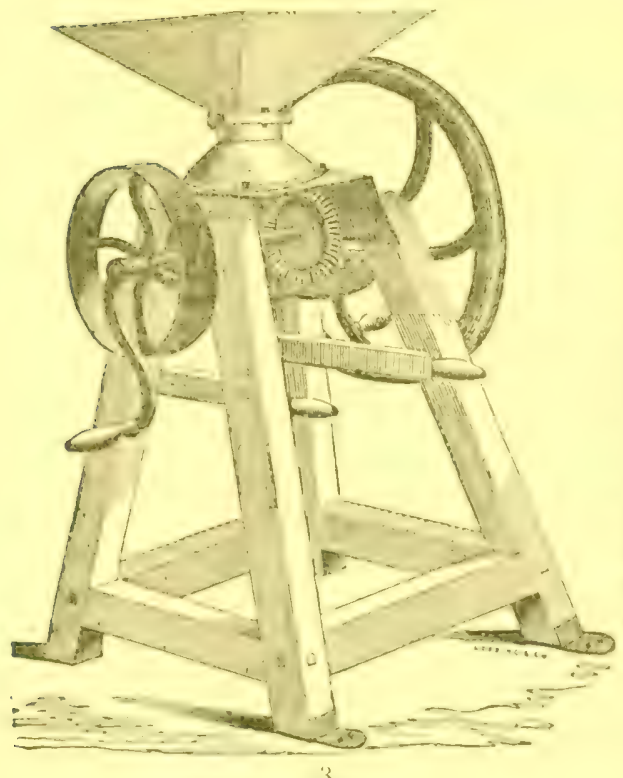

Fig. 36 represents 8 valuable iron mill, very ef. ficient and durable, to run either by hand or horse pow. er. With the latter it can be made to grind 4 bushels of grain fine perhour, and a greater quantity if coarse. Like the foregoing machine, it is simple, and not liable to get out of repair ; and when the plates or grinding sur. faces are worn out, they can be replacea by others at a small cost. These can always be had with the ma. chine. 


\section{HaNd Grain-MrLl.}

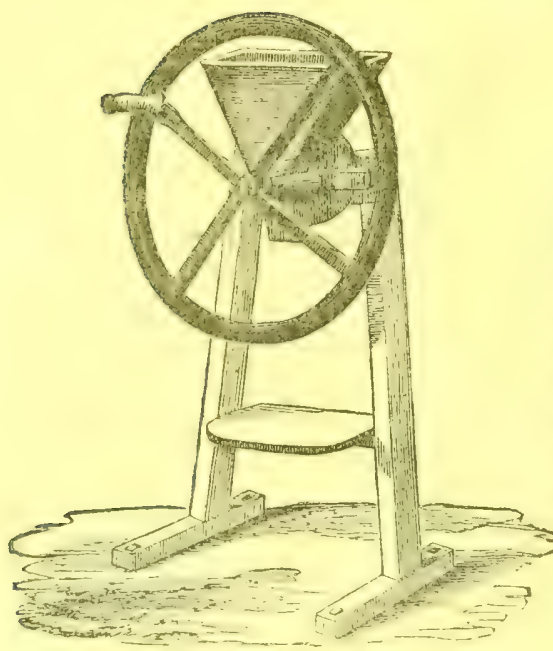

Fira. 37.
Fig 37 is used for grinding grain, coffee, and spices, as desired. It is usually operated by hand, though it can be constructed to run by other power. It grinds from one to two bushels per hour. When the plates or grinding surfaces are worn out, they can be replaced as in the foregoing ma chine

\section{Cof Fee-Mrld.}

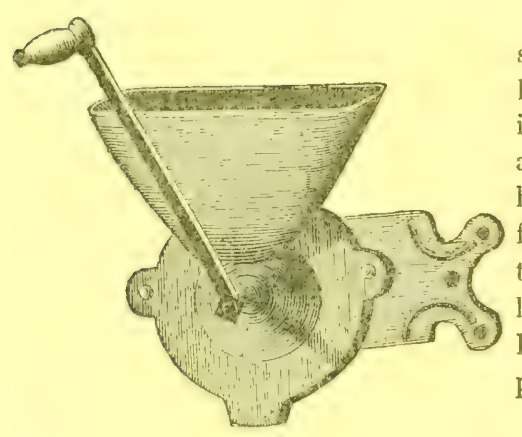

Fig. 38 is properly a coffee or spice-mill, but will grind grain of any kind. It is sold without a frame, and is so constructed as to be fastened to a post or board in any part of the house; or it can be attached to a simple frame. It grinds from eight to six. teen quarts per hour, depending main. ly on the speed at which it is run It may be had with or without extra plates.

FIG. 38.

\section{Fitzgerald Corn and Flodr-Milz.}

This is a small conical burr stone, hand or horse-mill, which, when well nade and properly put up, is very popular in many of the Southern States This mill is shown attached to horse-power. fig. 45. 


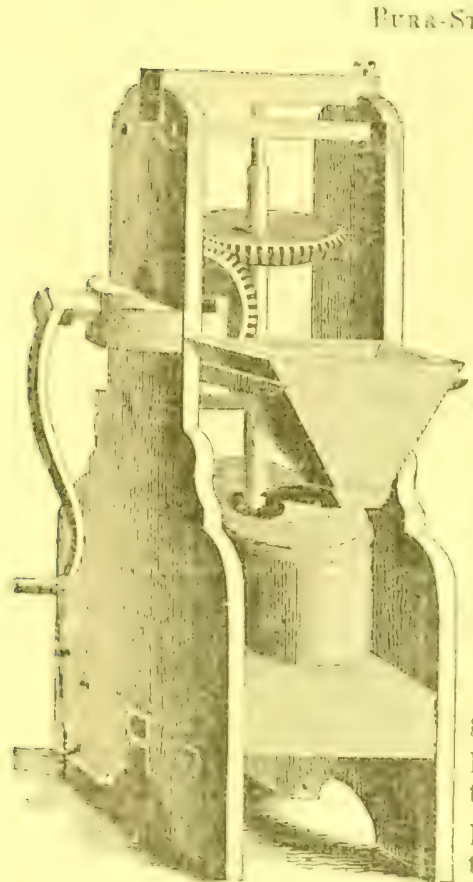

F1G. 39.

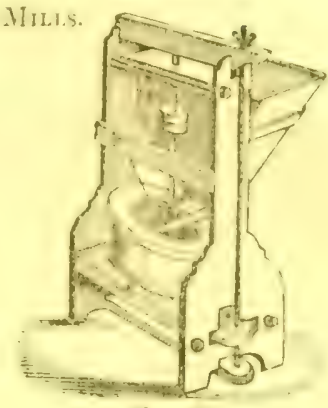

Fu. $34 !$ !

These mills are adapted for grinding all kinds of gain.

16 inch stones grind $2 \not$ bushels jer hour 20 " " " 3 " 3 " 3 24 " " " "3 " " 30 " " $" 5$ " 5

These mills are ready framed and rig. ged to attach the power, and are nore particularly designed for plantations it the South. When we speak of therr performance, it is to be required that they should be driven at a proper speed and with sufficient power.

li! $1:-1$ t $1.1 .1 \mathrm{n}$.

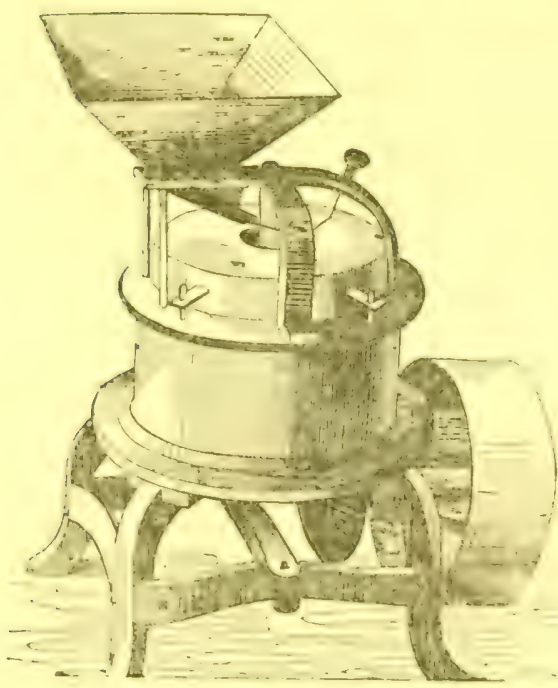

This machine 15 one of recent improvement, and will hull from two to ten bushels per hour, according to its size. We hare them of various patterns.

Fic. 10. 
STRAW-CUTTERS.

AlLEN'S StraW-CutTer.

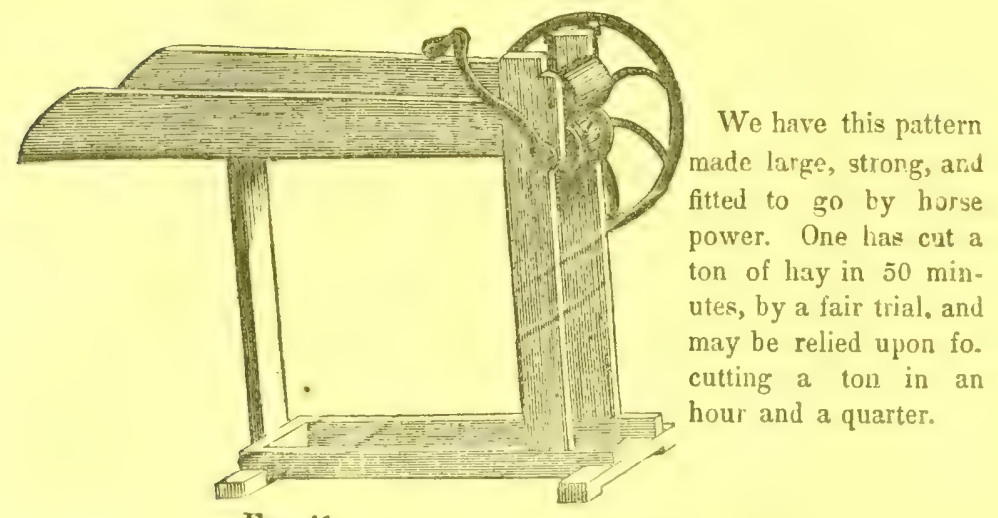

Fia. 41.

Cylindrical Straw-Cutter

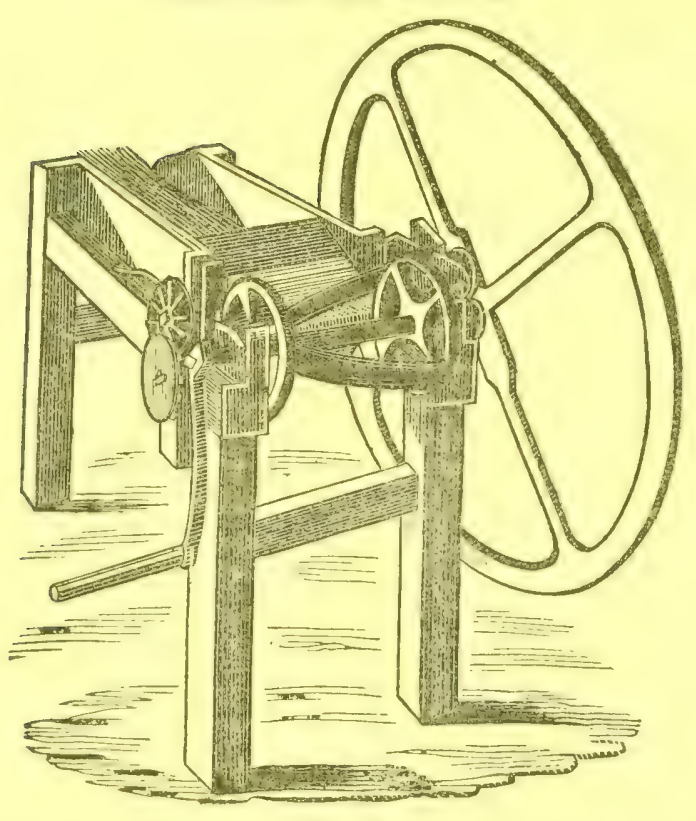

FIg. 42 .

The knives in this machine are of spiral form, and act on a bed-steel in such a manner as to cut with great ease, without a very keen edge; many thousan bushels have been cut with them without sharpening the knives. They car. ve regulated to cut longer or shorter. This is one of the best machines in use for cutting hay and straw by hand. They are a heavy, strong machine, and are 
much used at the South. There are four different sizes, having 9, 11, 14, and 20 inch knives. The larger sizes are rigged to be worked by power, and the smaller by hand.

\section{Common Hand Straw-Cutter.}

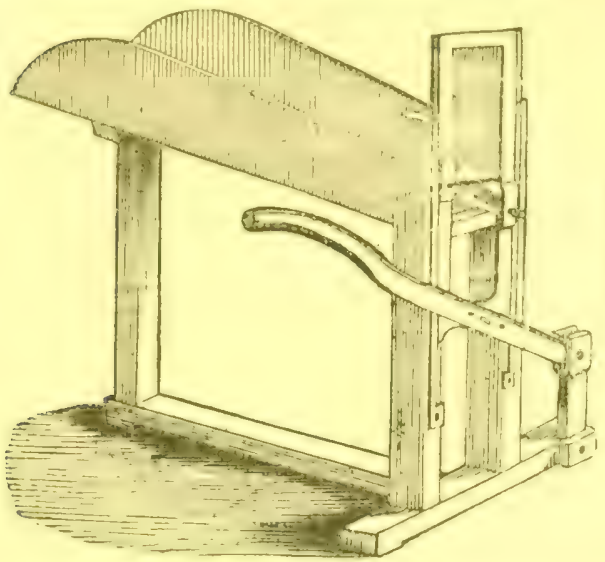

With these the straw is moved up by hand, and the knife is used by hand-lever. It is a very simple machine, and easily kept in order; though when more than one or two animals are fed, larger machines will be preferable

TIE GREAT UTILITY OF IIAY, STRAW, AND CORN-STALK CUTTERS.

There is great saving in the cutting of corn-stalks, hay, and straw, in two ways. The animals do not waste it by drawing it out of the mangers, and trampling it under their feet, and time and labor are saved them in masticating They obtain their supply of food realily, and then lie down to digest it Fermentation also developes the nutritive matter, and requires less wor for the stonach, and this, by saving muscular exertion, leaves more strength with the animal to be expended on ordinary work. The same principle holds with milch cows, sheep, \&c. If the food be given to them in a form more readily adapted to assimilation in the animal system, the greater the product of milk, wool, flesh, \&c., they can yield from the same quantity. Cutting, bruising, grinding, fermenting, and cooking the food, all tend much to fit it for easy and rapid digestion, and whenever it can be thus prepared, without too much expenditure of labor, it should be done. By adopting a mixed food, much of the coarser products can be worked up, which are now suffered to be added to the manure heap. Indeed, scarcely any of the vegetable productions of the farm need be suffered to run to waste, till they have first contributed all the nutriment they contain to the support of animal life. By chopping these up fine, and properly cooking and seasoning them, they will be eaten with peculiar relish, easily digested, and go twice as far as in the ordinary method of feeding.

Both hay and straw should be slightly wet, and seasoned with a little meal and salt, for several hours before it is fed to the stock.

For eutting hay, straw, and stalks, those machines work with great ease and rapidity, having knives set to cut against a roller of raw hide as in fig. 11 
The machine is a perfect self-feeder, without any extra and complicated fixture to perform that part of the work.

For this kind of cutters, crooked or spiral knives have been mostly used, which could not, without much difficulty, be properly sharpened or replaced except by the maker, subjecting purchasers to much inconvenience and expense. Some manufacturers confine the knives to the cylinder by means of flanges, sloats, and screws. Thus the knives are weakened, and the screws are liable to be lost or injured, and the flanges prevent the knives being placed upon the cylinder so near each other as to cut the straw as short as is by many thought to be necessary.

Important improvements have recently been made in the construction of this kind of machines, by using straight knives, confined by a simple cap, and placed in such a manner upon the cylinder that they perform the work in every respect as easily and expeditiously as the spiral knives. Thus improved, the machines possess several very important advantages.

The knives being straight, as in figure 41 , are readily ground or sharpened by the purchaser; and they can be replaced by a common blacksmith when worn out or broken. The knives are made heavier and attached to the cylinder without sloats or screws, and are confined at both ends and supportec in the middle in a manner much stronger and less complicated, thus leaving the strength of the knives unimpaired, and avoiding the great liability to twist. cripple, and break. The manner of attaching the knives to the cylinder admits of their being placed near each other, so as to cut as short as is desirable, and the hide-roller, when used with straight knives properly set, will last much longer than when used with the spiral knife.

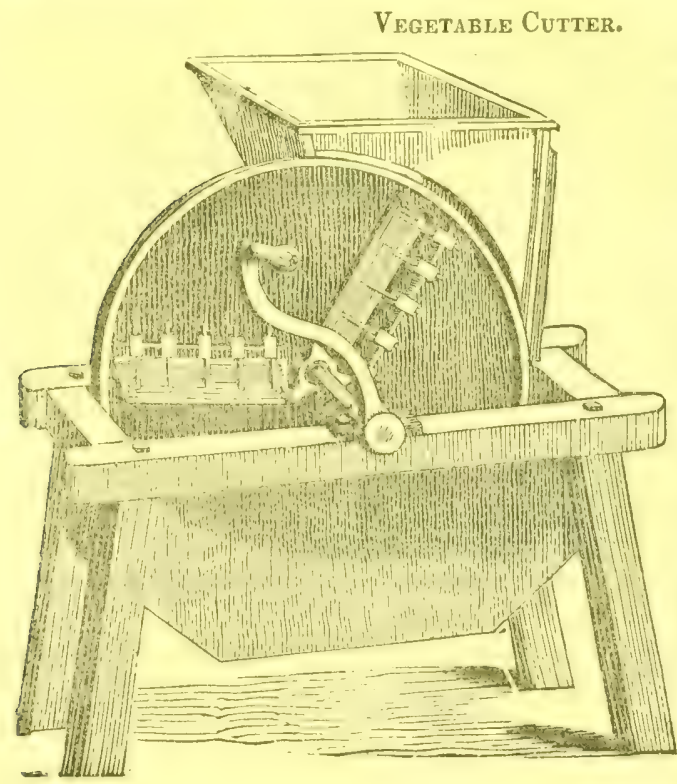

The cutting wheel of this implement is made of cast iron, faced on one side, through which is inserted three or more knives like plane-irons These cut the vegetables into thin slices with great rapidity, and then, by cross-knives, they are cut into slips of convenient form and size for cattle or sheep, without danger of choking. The pieces after cutting lie loosely, and can easily be taken up by the animal. The machine will cut 50 bushels per bow Fia. 44. 
AGRICULTURAL AND IIORTICULTURAL TOOLS.

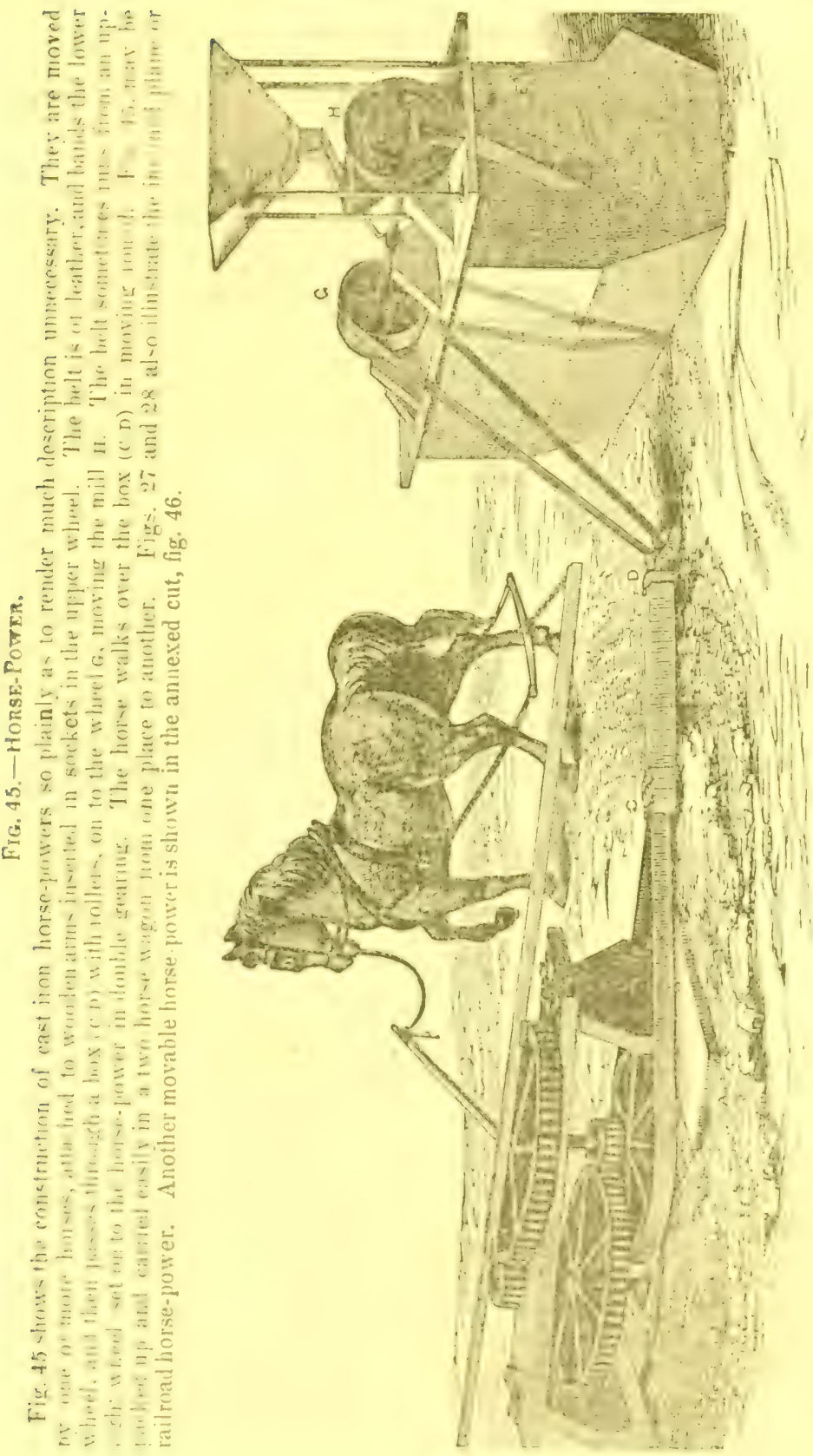




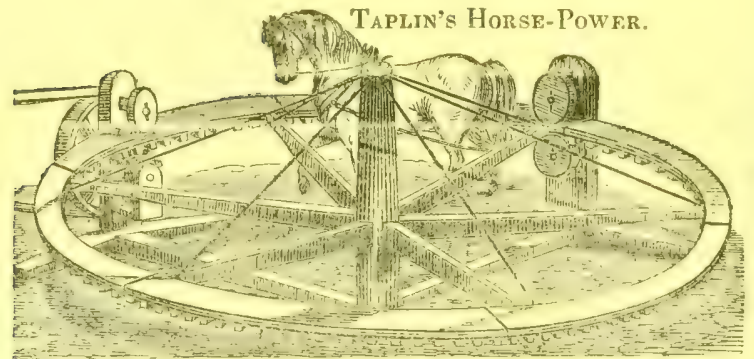

FIG. 46.

There is another kind of circular horse power, with a wooden rim, or a circle of about 20 feet diameter, to which iron segments are bolted They gear into a cog wheel which moves the machinery by a belt, or may be made to gear on to it by cast iron wheels. From one to six horses can travel round inside of this rim, and thus move the power. Many prefer this power to all others, although it requires more room. It is not complicated in its construction.

RAISING W ATER BY HORSE-POWER.

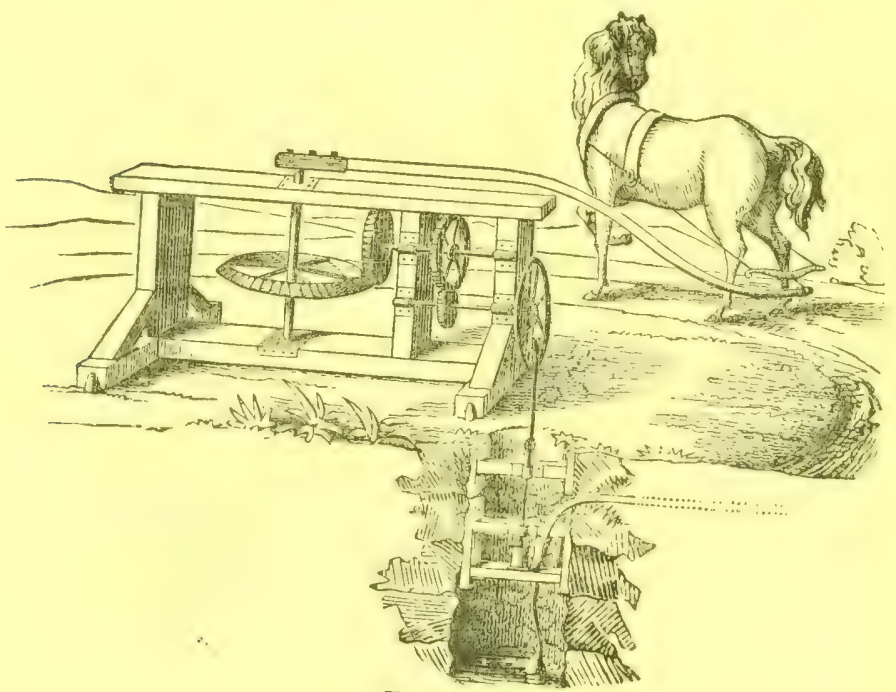

Fig. 47.

Machines to work pumps are generally made stationary, ant on a more simple plan than such as are movable.

The circle for a horse to travel in, to work a power to advarılage, ought to be twenty-five feet diameter, and a horse will pass round on an average about three times a minute. In order to get twenty-five revolutions to the crank, the large whecl must be eight times the diameter of the small one, or eight feet to one foot, if of cast-iron. But if made on the plan represented in cut (fig. 47), the large wheel may be made of wood with iron segments. In that case it would be well to make the large wheel twelve feet, and the pinions eighteen inches, as the friction is less when the wheels are larger. 
MISCELLANEOUS IMPLEMENTS AND MACHINES.

Cistern Hann-l'Uup.

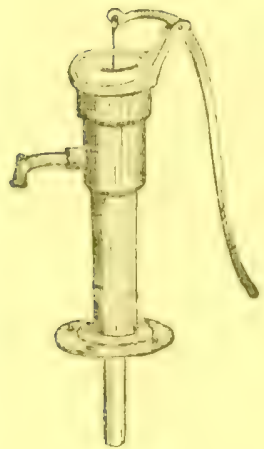

FIc. 49.

This implement is made of cast-iron, and answers an excellent purpose for raising water from a cistern, or clsewhere, from a depth of twenty-five feet. It works well with a one and quarter inch lead-pipe.

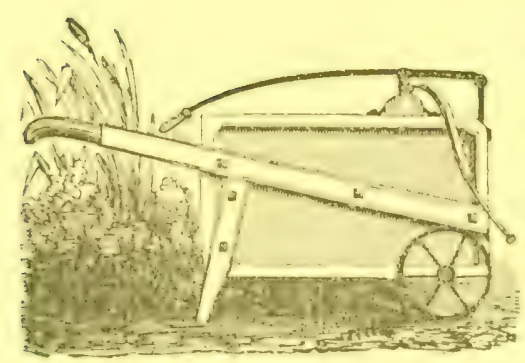

Frg. 49

G:IIIS- Triase.

The box of this engine will hold 40 gallons. It is made with light wheels and handles, so that one person can wheel it. A double-action pump, two and a half inch cylinder, will throw water seventy feet horizontally, and forty feet high, with one person to work it. "They are well calculated for watering gardens, washing windows, destroying worms on trees or shrubbery; extinguishIng fire in buildings, \&c. Water diluted with sulphur and thrown on plants, will destroy the worms on them

\section{Syringes, and Haxin Force-l'umps.}

We have several sizes of these and the garden syringe, which are much used for various purposes in the garden

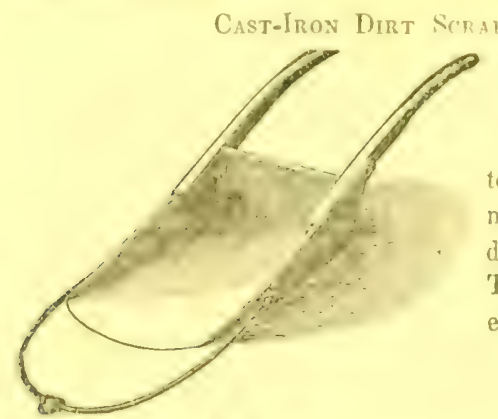

This kind is found to be far superion to anything for the purposes of roal. making, lerelling hills, filling hollows, digging wide deep ditches and cellars They are foumd very convenient on every farm and piantation.

Fro; 50. 


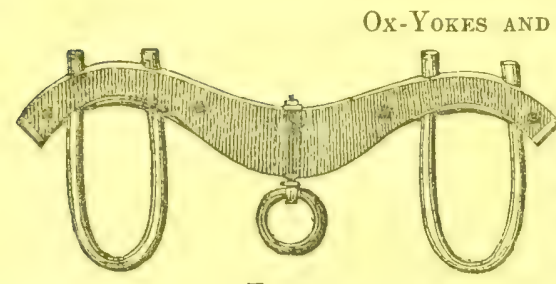

F1G. 51 .

A good yoke is of great importance in securing the greatest amount of labor, with the utmost ease to the cattle. Such as are poorly made, or constructed on bad principles, are almost worthless; as they greatly diminish the labor, and often seriously injure the oxen. We have several kinds and sizes.

\section{Cattles-Tir.}

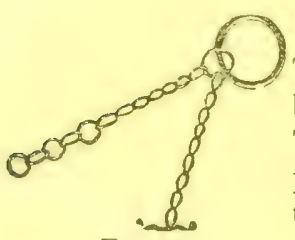

Fic. 52 .

Fig. 52 is a chain for tying up cattle in their stalle The large ring goes over a stationary round post set up by the manger, and the chain is fastened to the horns. The hook at the end of the lower length of the chain is passed through either of the rings in the upper length, to suit the size at the base of the horns. It may be thought that this chain wears off the hair on the head of the animal, but this is not the fact. It is the neatest and most secure fastening in use, and at the same time the most comfortable; as the animal slips the chain up and down the stationary post, by the large ring, as it wishes to move its head in feeding or getting up and lying down; it can also turn and lick itself when thus fastened.

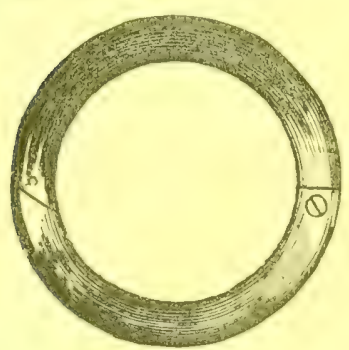

\section{Bull-Rings.}

A bull is easily rung, by punching the cartilage between the nostrils, and then inserting the ring and screwing it together. With a ring in his nose the most fractious animal is easily managed.

Balls. These are brass or composition. They are screwed on the ends of the horns, and thus prevent animals from injuring each other.

FIG. 53.

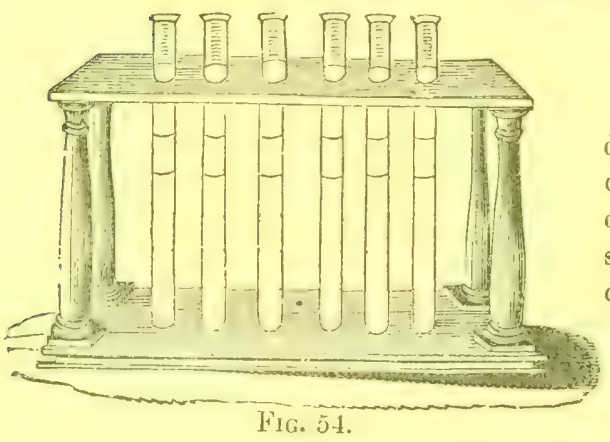

This instrument is used for determining the quantity of cream contained in milk. For description and mode of using see page 171, vol. v. American Agriculturist. 
Cylindrical Churn.

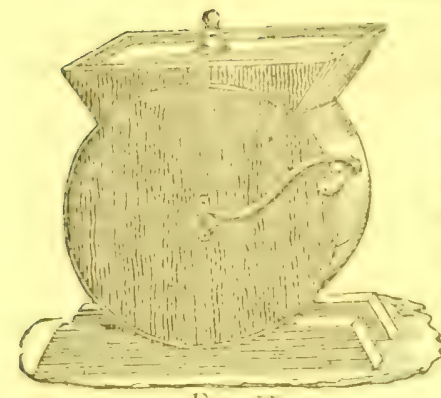

Fili, jis.

This is the best in use, as it is simple in

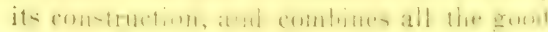

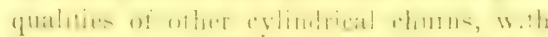

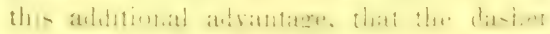

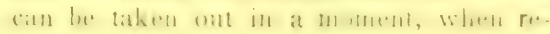
qunired to be cleansed. This is important it ter every churning, in order to keep it swett and avoid taint to the cream.

\section{Thermometer Ciunn.}

The Cylinder Churn has recently been improved, by placing a themometer in the side, which indicates the temperature of the cream within. To make the greatest quantity of butter in the least time, this should be at $55^{\circ}$ Fahrenheit, at the commencement of the operation, and gradually rise to 63 or 65 , at which it should stand when the operation is concluded. A double metallic bottom is constructed, in which warm or cold water, or even ice may be placed, so as to regulate the temperature. They are one of the most important of the dairy improvements of the day.

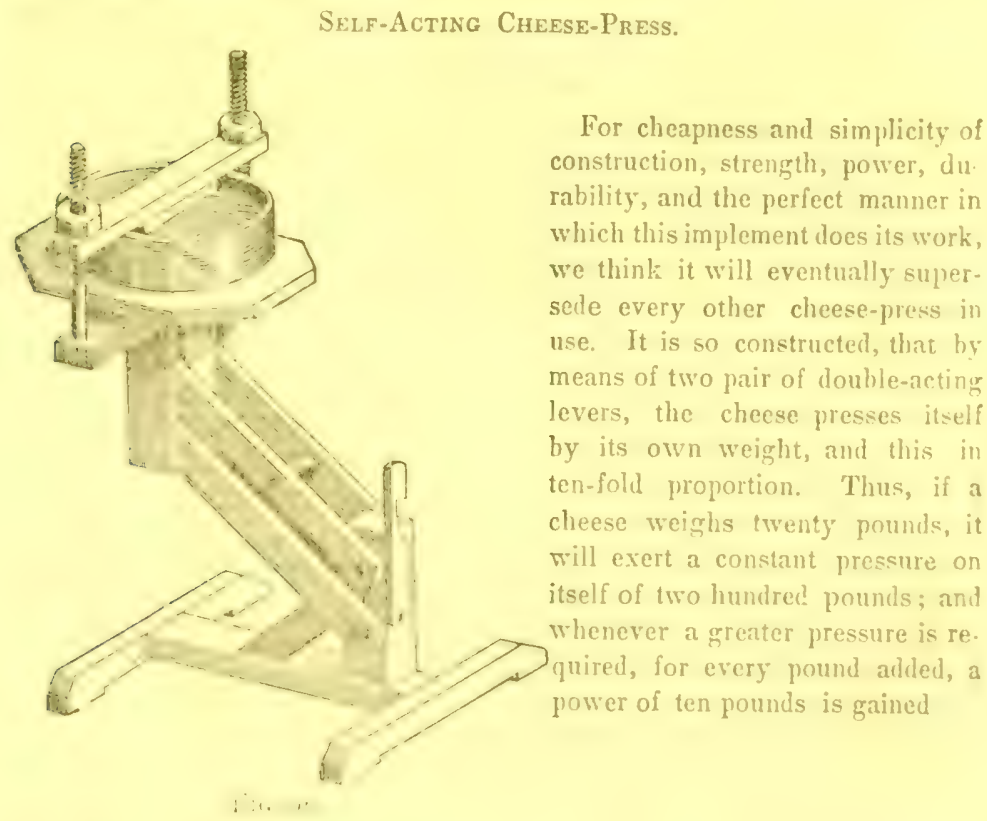




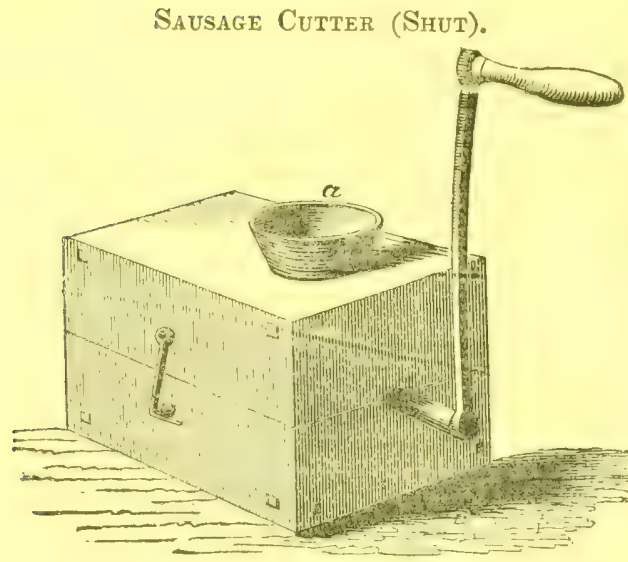

FIG. 57.

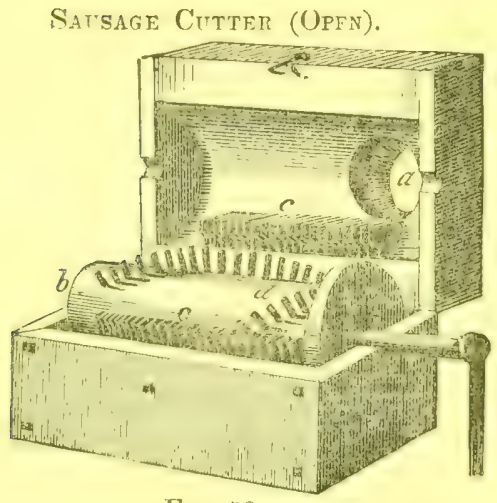

F1G. 58.

SaUsatil: NTtFfer.

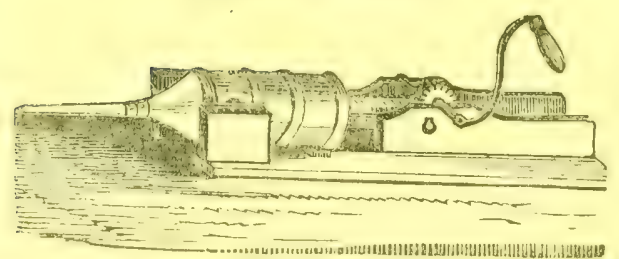

FIG. 59.
This implement consists of an oblong box, 13 inches in length by about 8 in. square, with a cavity $5 \frac{1}{2}$ in. diameter through the centre, and closed at each end. A hole on the top of one extremity for a small hopper,receives the meat, while another in the bottom, at the opposite end, discharges it. A crank at one end turns a solid wooden cylinder in the centre, to which are attached two or more rows of spiral iron pins, that press the meat outwardiy through a succession of sharp, steel knives, set within the box. It is made finer or coarser, according to the rapidity with which it is fed. One machine will cut from 1,000 to $1,500 \mathrm{lbs}$. per day. Price $\$ 5$ for No. 1 , and $\$ 10$ for No. 2.

We have several sizes of other sausage cutters, with a vertical cutting knife following upon the meat, which revolves in a pan. Price $\$ 15$ to $\$ 25$.

This rachine will save the labor of eight or ten persons, and the work is done with great ease. 
Grass MIm.K-PANs.

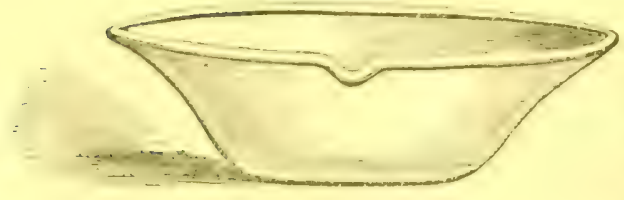

FIG, 591.

These can be furnished on order, with or without covers, to hold from four to twelve quarts each. They are more easily kept sweet and clean thin if made of metal, wood, or stone, and are not liable to sour the milk by the electric changes in the atmosphere.

Patent Bee Hives.

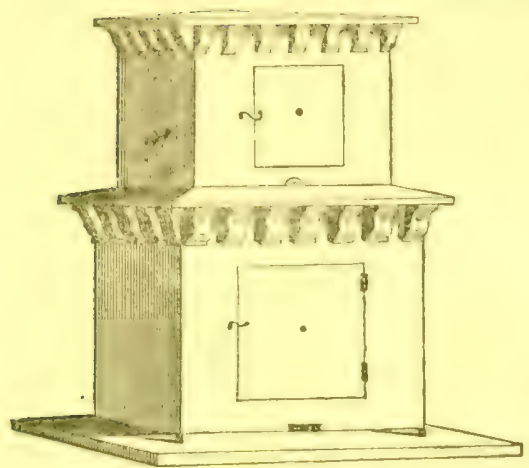

Of these, we have a great viriety of patterns, and of the latest and.best improvements. 'They are so made that it is not necessary to destroy the bees to procure the honey. The lower apartment is appropriated to storing the bee bread and rearing the young, while the pure, fresh comb is taken from the top, as often as necessary, without disturbing the operations of the bees.

$F_{I(j,} 60$.

Bush or Root-Pulier.

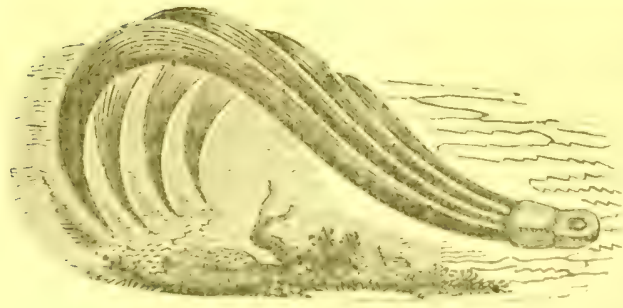

FIG. 61 .

This is a very useful $1 \mathrm{~m}$. plement to attach to bushes, clumns of roots, and bogs, for the purpose of pulling them out of the ground. It is made with two, three, or four claws. These are hooked to the bush close to the ground; the cattle are then attached to it by a ehain, when the bush and roots are easily hauled out. It will do the work of half a dozen men in clearing and grubbing.

Brush ant Brantber-Hook.

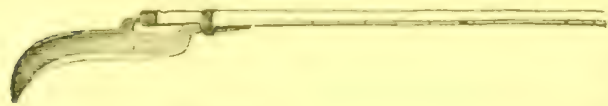

Fic 62 .

A strong and useful imple. ment for cutting brush or briers ahout fences, or in clearing or underhrushing groves or forests. 


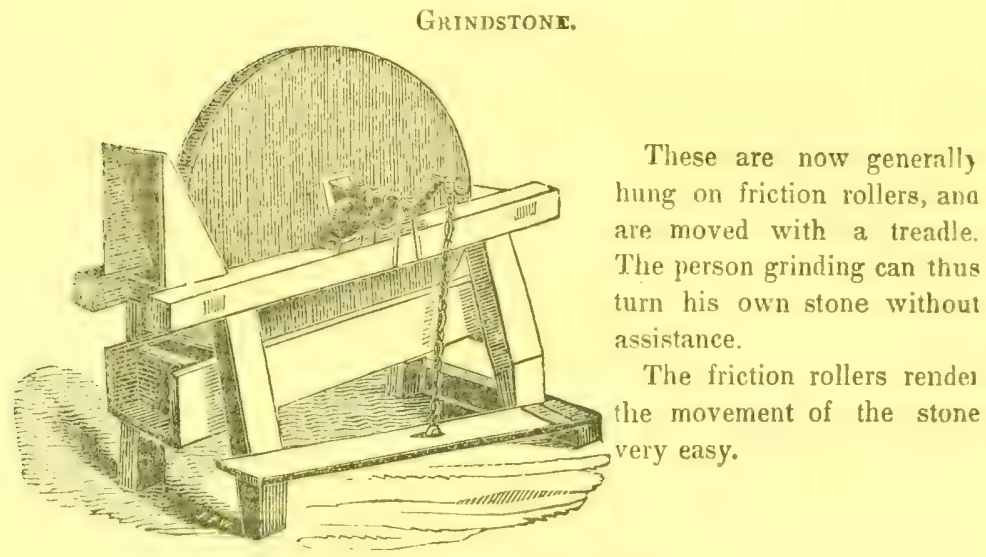

FIg. 63.

HAND-TrUCK.

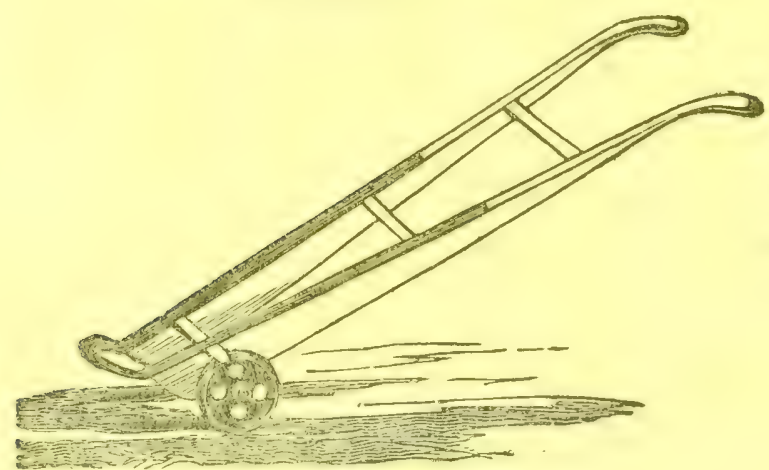

For trucking by hand, boxes, bales, \&c., in the store. They are of various sizes.

FI: 64

Wheel, and Canal, Barrow.

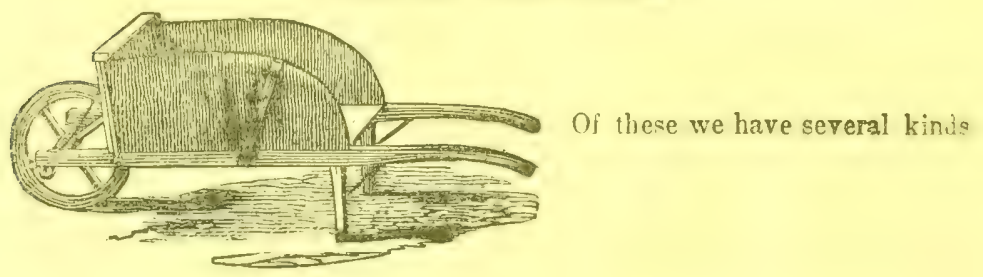

FIG. 65 .

Steam-Engines and Bolrers.

These can be supplied, on order, of the best finish, and warranted; and a. prices as low as they can be found in any part of the United States. 
Centre-Scales.

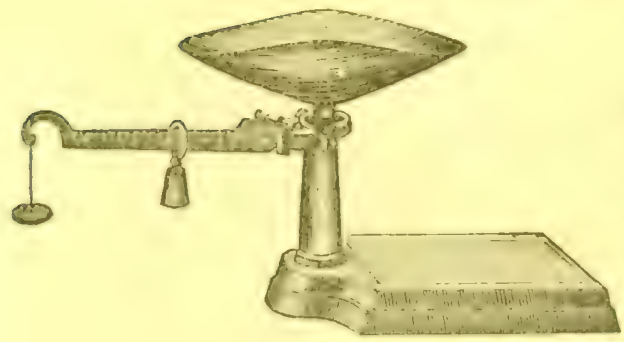

These are made with the same accuracy as the plat. form scales, but much lighter to weigh smaller quantities. All of the foregoing can be furnished hoth at wholesale and retail.

FIG, $65^{*}$

Jyrroyed Elghe Cotton-Gin.

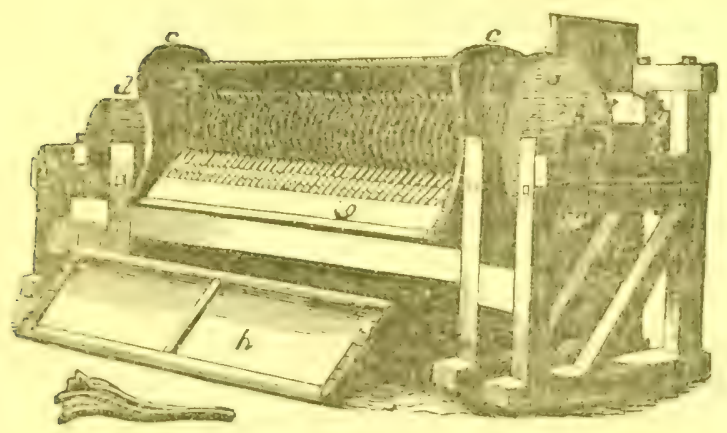

FIG. 66.

Description. - $n$, driving brush pulley; $b$, slide ; $c, c$, end boards ; $d$, cylinder pulley; $e$, top board; $f$, saws; $g$, grate fall; $h$, seed board, with a section of the patent grate below it; $i$, idler pulley. The above machines will be supplied on orders.

Fire-Proof Iron Chest.

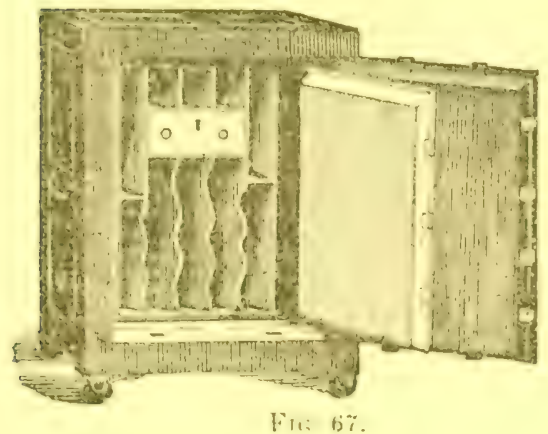

These can be furmished of all sizes. They afford safety for valuable papers, money, plate, jewelry, sc., not only agrainst fire, but, when properly constructed, they are proof against a:ly ordi. nary attempts at robbery. 


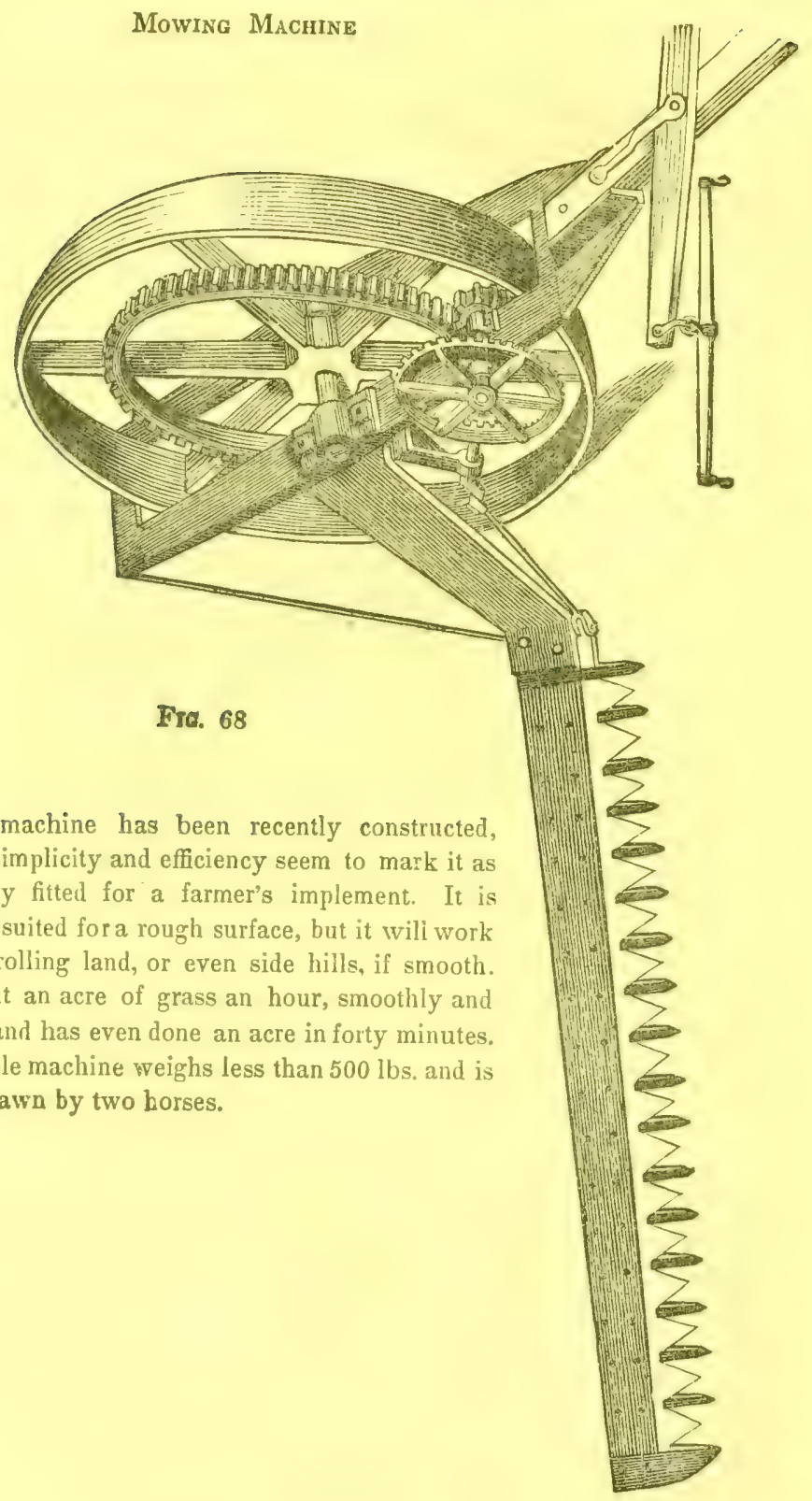

This machine has been recently constructed, and its simplicity and efficiency seem to mark it as peculiarly fitted for a farmer's implement. It is not well suited for a rough surface, but it wili work well on rolling land, or even side hills, if smooth. It will cut an acre of grass an hour, smoothly and evenly, and has even done an acre in forty minutes. The whole machine weighs less than $500 \mathrm{lbs}$, and is easily drawn by two horses. 


\section{Brick-Machine.}

These can ne furnished on order, of different patterns. They are worked by hand, and will turn out, of a good and uniform quality, as many bricks as can be made by two or three good moulders in the ordinary mode. Some of these machines make a very superior quality of pressed brick, which command the lighest price in market. When several occupy the same yard, a steam-engine may be used for mixing the clay in the place of the ordinary horse power, which will greatly facilitate the operation and lessen the expense.

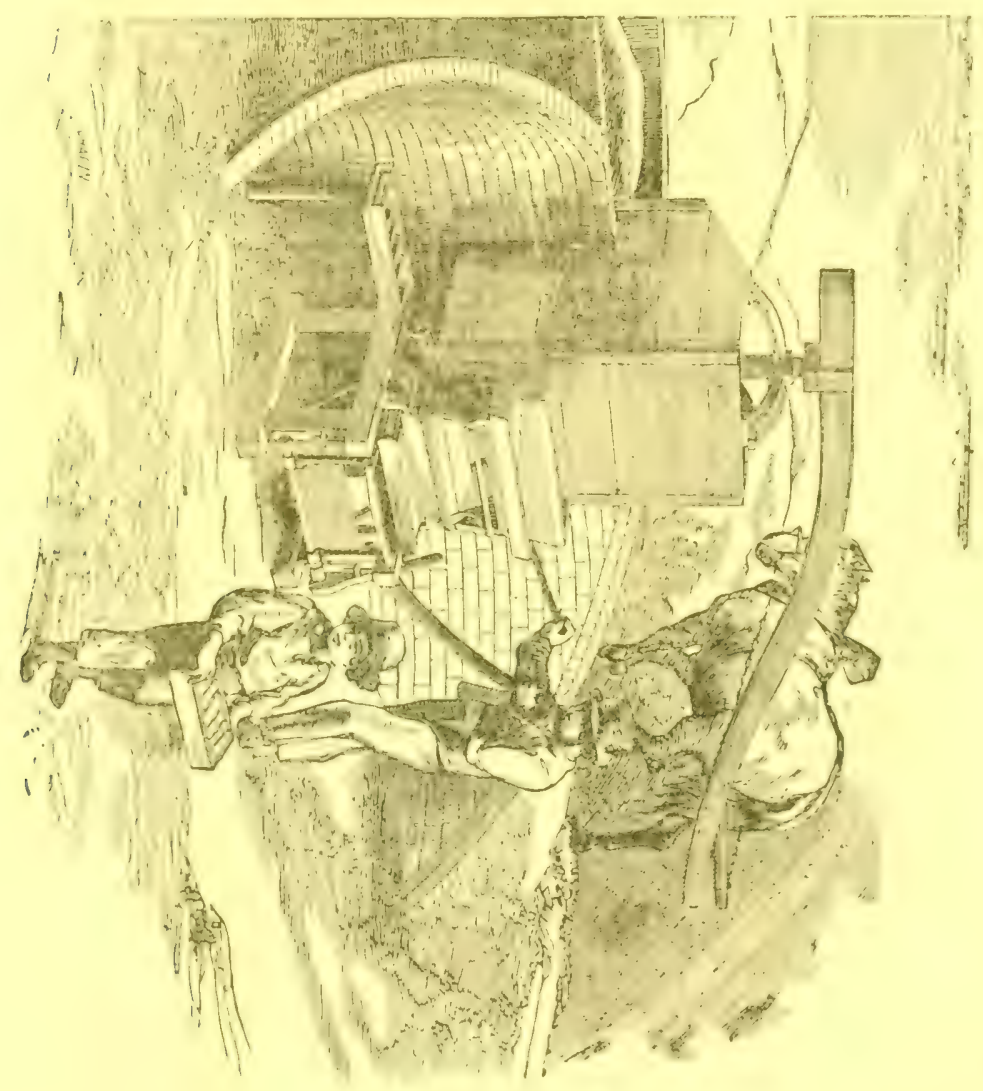

FIG. 69

StGar-Crishers.

We have these of three differeut sizes. They will crush from 4 to $10 \mathrm{hoga-}$ heuds a day. 


\section{HORTICULTURAL IMPLEMENTS.}

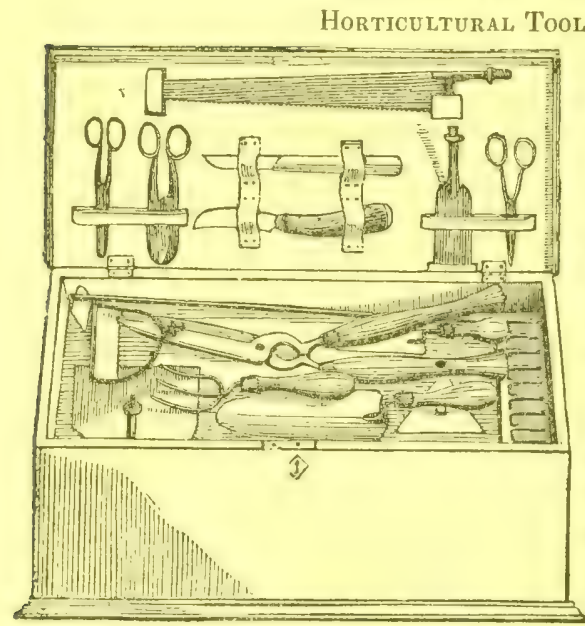

The convenience of having at hand the requisite tools or implements for gardening and prun. ing purposes, to be kept in a place where they can always be found, is obvious to every one. If suffered to lie, or be scattered about the premises, they are liable to be mislaid or lost, and more time is spent in looking them up than they are worth. This is obviated by using a small tool-chest purposely adapted to keep them. It is very complete, containing quite a va-

FIG. 70 . riety of implements, only part of which are shown in the cut

Anderson's Patent Hammer.

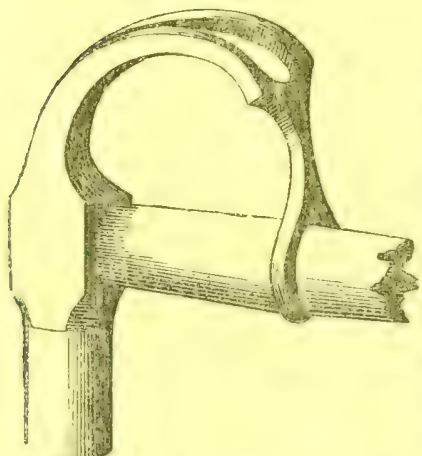

This is a recent invention; the claw, as will be seen by the cut, extending to the handle and clasping it with a strong ring, which makes it impossible, in drawing nails, for the handle to give way, draw out or become loose. The face of the patent hammer will thus always remain true, it being kept at the same angle with the handle. These ham mers are made of cast steel of the best kind, and in a very superior manner. Six different sizes are now made, weighing from half a pound to one and a half pounds.

FIG. 71.

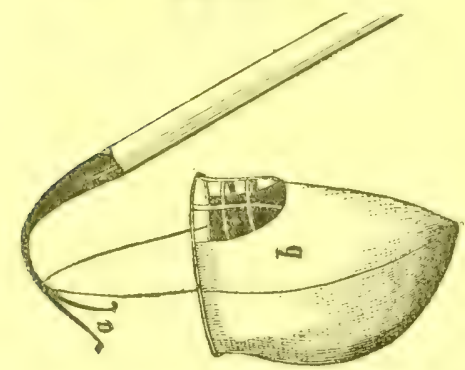

\section{Frutt Gatherers.}

These are very useful in gathering fruit from high branches. This is done by placing the implement on a light pole of any length required, and slightly jerking or pulling the fruit into the bag suspended from the fork which detaches the stem

Fia. 72. 


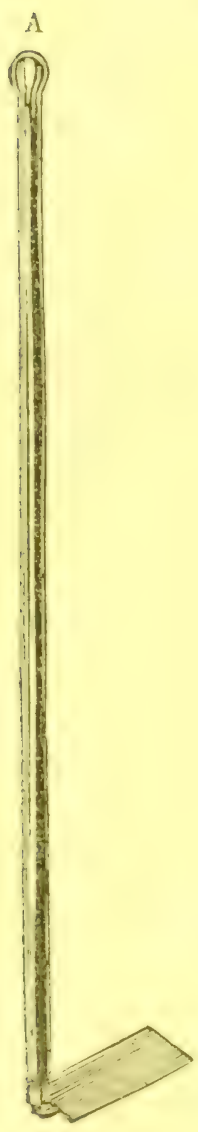

HOES, SPADES, PICKS, SHOVELS, \&C.
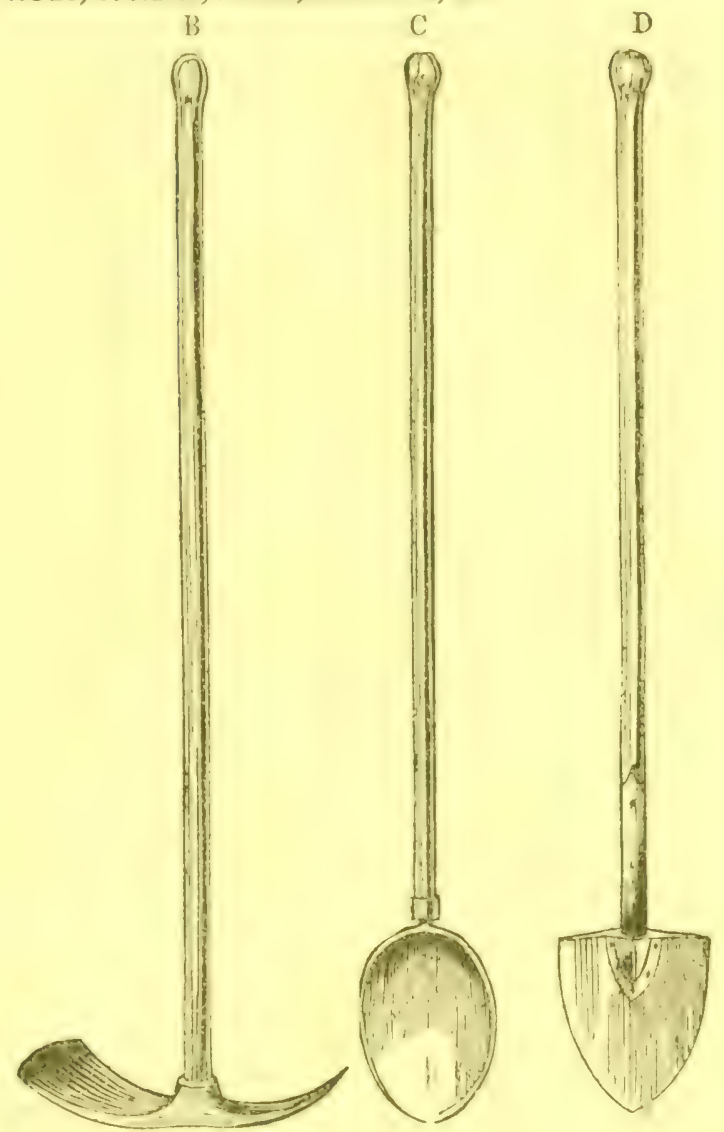

FI\%. 74.

$A, B o g$ and heavy field hoe.

B, Bog-hoe and Pick attached.

C, Post-spoon for digging post holes.

D, Round-pointed shovel.

Common hoes of all kinds.

Besides the ordinary kinds of hoes, we have different sizes of the choicest kinds made expressly for the cultivation of sugar, cotton, \&c.

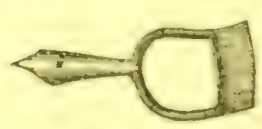

FIc. 75 .

Dutch or Shuffle-Hoe.

From three to twelve inches wide, used for weeding and stirring the earth. 

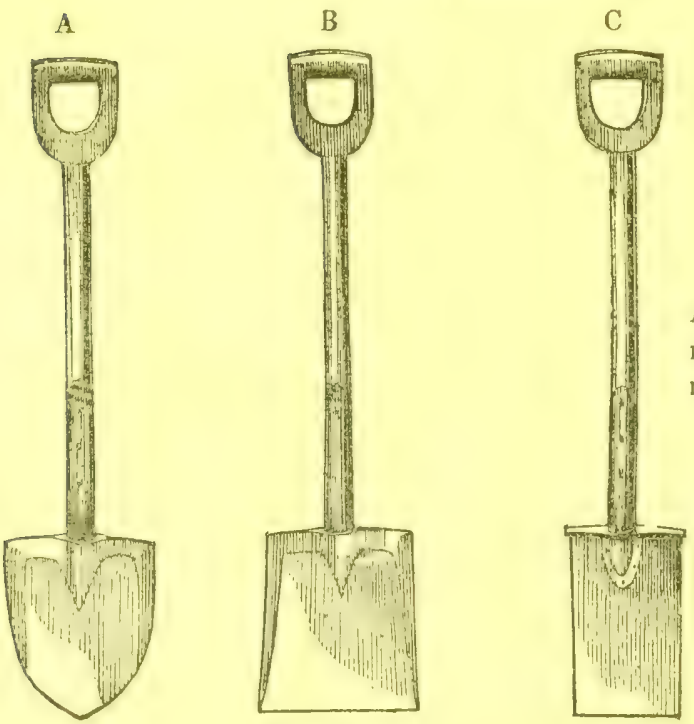

Of these we have Ames', and a great va. riety from the best manufacturers.

FIG. 76 .

\section{PitchForks.}

Pitchforks of different sizes, very strong and elastic. They are made by several manufacturers, with two, three, and four tines each.

\section{MANURe Forks,}

A

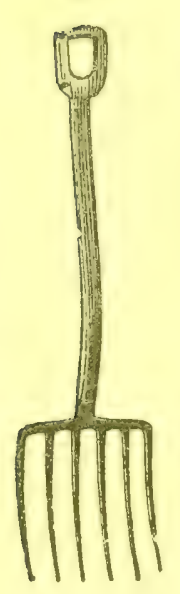

B

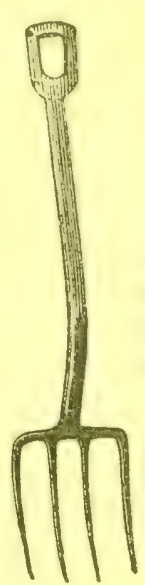

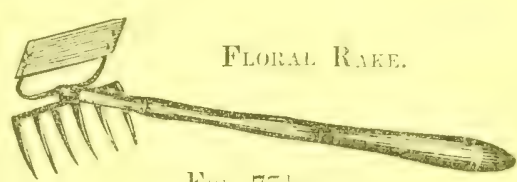

Fiti. $75 !$

The best forks are cut out of a plate of cast steel, and have from four to eight tines each. They have all the elasticity of a steel ramrod. They are strong, and very durable if properly hand!ed. We also keep a large assortment of the common kind of manure forks.

FIG. 77

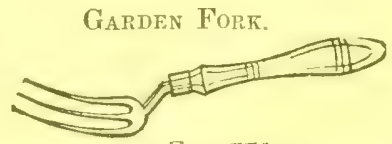

FIG. $77 \frac{\pi}{4}$. 
Scuffler, Trower, and Hor.

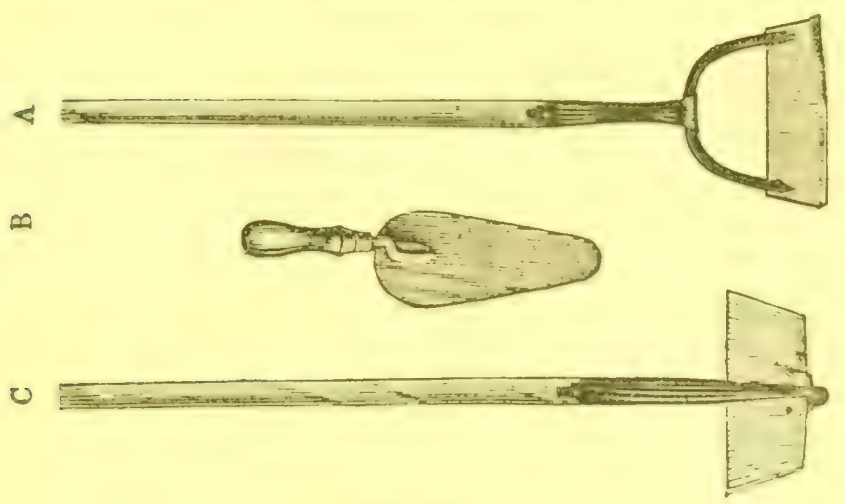

FIG. 78.

A, Garden-scuffler.

$B$, Transplanting-trowel, very useful for transplanting flowers and plants.

$\mathrm{C}$, Weeding-hoe.

\section{Pruning.Sat aNd Chisel.}

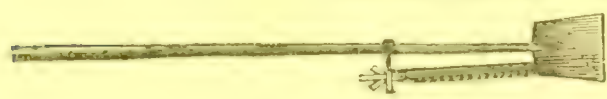

The blade of the saw is about 12 inches long, attached to the blade of the FIG. 79. chisel at one end and to the gocket of the chisel handle at the other end. The chisel is 3 inches wide by 4 inches long, made thin, and of the best cast steel. A wooden handle of conrenient length is inserted in the socket handle, enabling a person to stand on the ground and trim his trees.

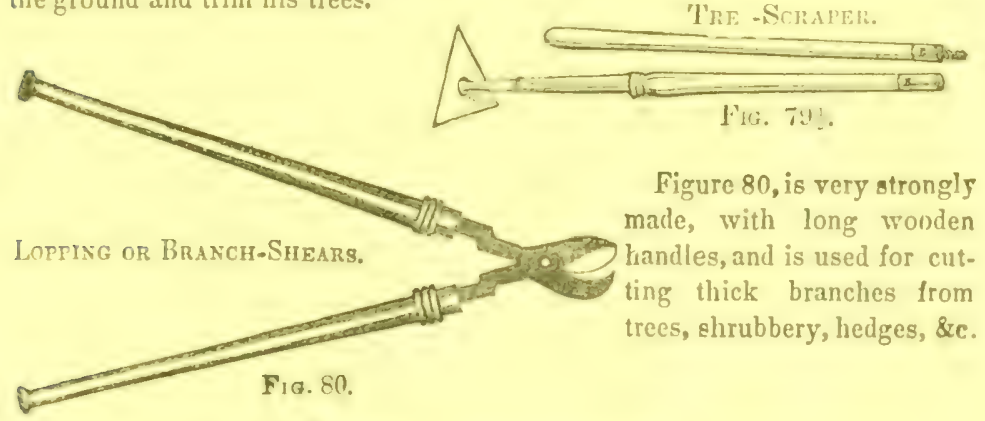

Prunivg-Scissors with Botrs.

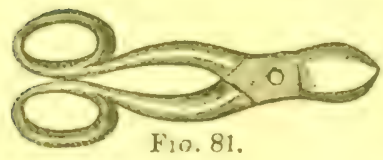

Fig. 81 , is adapted to pruning small twigs, cutting flowers, \&zc., and is a very useful arti. cle for ladies. 


\section{Sliding Pruning-Shears.}

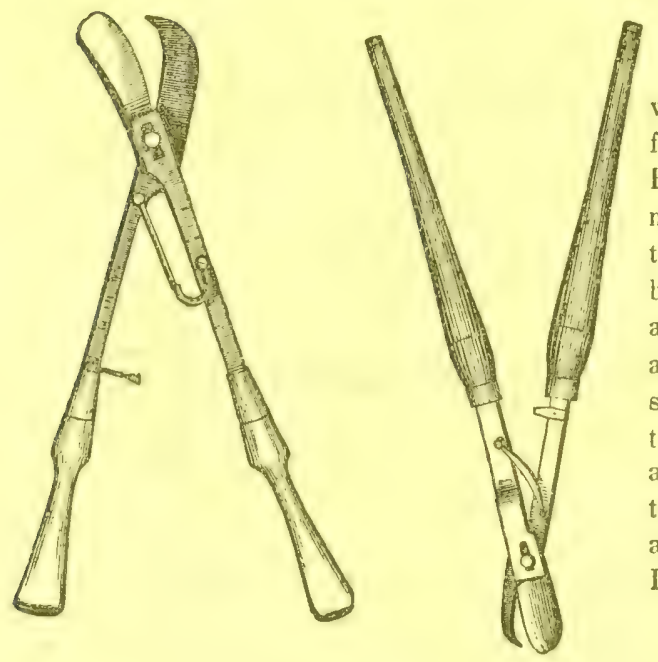

These instruments have wooden handles, and differ from the Lopping or Branch shears, in having a movable centre for the motion of one of the blades, by which means, instead of a crushing cut, they make a. draw cut, leaving the section of the part attached to the tree or shrub smooth, as if cut off with a knife; they are also much lighter and better finished than the Lopping shears.

Fia. 82.

\section{Garden or Hedge-Shears.}

A.

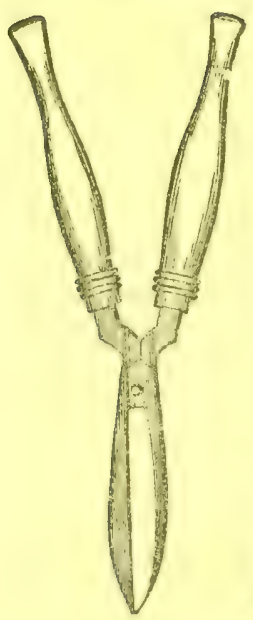

B

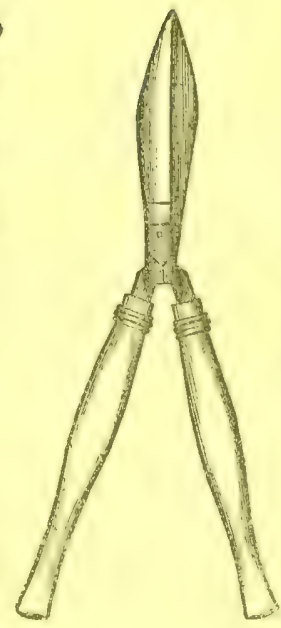

Fig $83, \mathrm{~A}$, represents this article without the pruning notch; $\mathrm{B}$ has the pruning notch, which is of advantage, when used for trimming hedges or shrubbery, as it enables the operator to cut much stronger twigs than could otherwise be cut by the shears.

Frg. 83. 
Grass-Finging or Border-Shears.

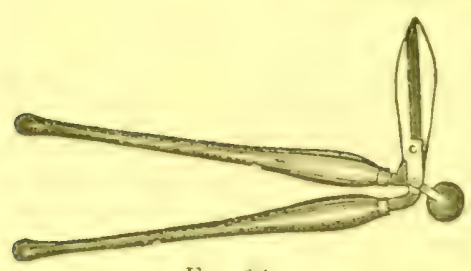

Fili, St

Fig. 84 is chiefly used for trimming the sides of box and grass edgings, and is constructed so that the operator may stand upright whilst using it, the one figured here has a wheel attached, which is generally considered an advantage

\section{LADIES' GARDEN-SHEARS}

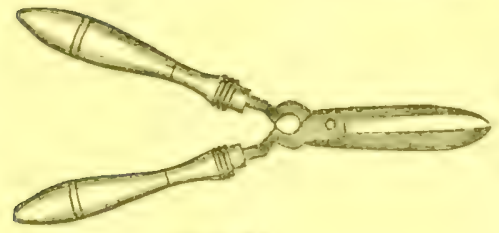

Fig. 85 is small, light, and neatly finished, and is very useful for trimming box trees and bushes, as well as for many other purposes.

Fig 85

Ladies' Pruning-Suears.

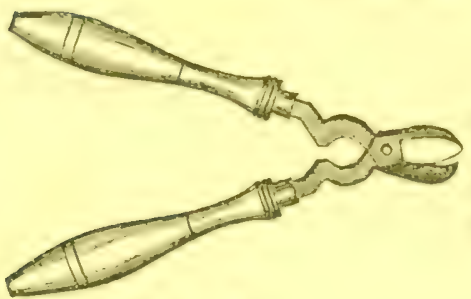

Fig. 86, with wood handles, are band. somely and lightly made; they are very useful in trimining shrubbery, \&c., which is too large to be cut by the hand-shears.

FI(. 86

Polee Pruning-Shratrs.

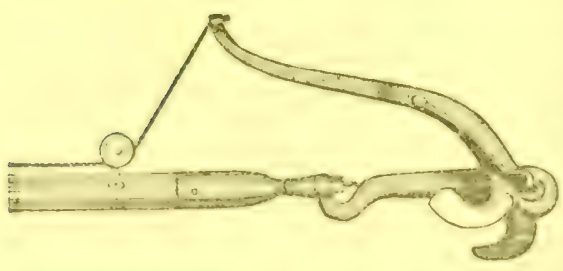

Fig 87 is attached to a pole, and operates by means of a lever moved by a cord and pulley. Its use is to enable a person. standing on the ground, to prune trees, some of the branches of which could not, perhaps, be as well pruned by any other im-

FIg. 87. plement. Branches of one inch and a half in diameter may be easily cut off with this instrument. Shears of this kind, of small size, are also very useful in cutting off from shade and fruit trees, small branches to which insects have attached themselves; they are also used for gathering fine fruits, which, when cut, will fall into a basket attached to the instrument when used for this purpose. 


\section{Pole Pruning-Nippens.}

Fig. 88 is a very efficient instrument, and

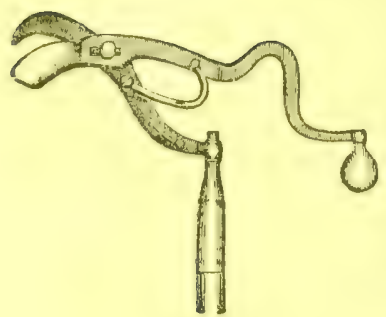
possesses the advantage of having a sliding cut, which lessens the labor of the person pruning, and leaves the branch which has been cut as smooth as if a knife had been used; this instrument is much superior to the pole pruning-shears, but will not cut a branch of greater diameter than one inch.

FIG. 88 .

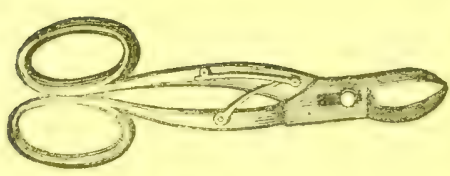

Pruning-Scissors.

Fig. 89 is very handsomely made, with sliding centre and spring, and is fitted with sheaths; these scissors cut as smoothly as a pruning knife, and for prun. ing rose bushes, \&c., are superior, especi-

F ${ }_{\text {IG. }} 89$. ally for ladies.

ViNE-Scissors.

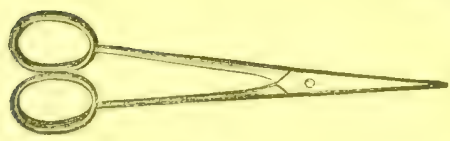

Fig. 90 is used for thinning out grapes, when they have grown too closely on the bunch; also for removing superfluous leaves, twigs, \&c.

FIti. 90 .

\section{Flower-Gatherer,}

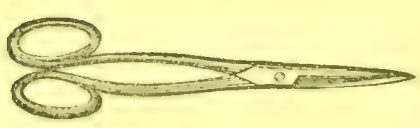

Fig. 91 is a pair of scissors combining tweezers or pincers; they are of great ad. vantage in gathering roses and other flowers which have thorny stems, as the

FIG. 91 flower cut by the scissors is held fast by that part which acts as pincers.

Hand-Sliding Pruning-Shears.

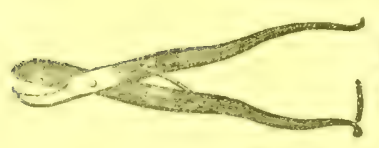

Fig. 92.

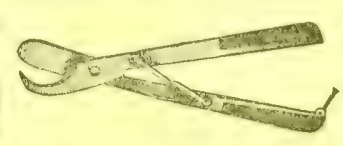

FIG. 93

Figs. 92 and 93 represent the iron handled shears, and, for gentlemen's use, are the best instru. ments for pruning roses, \&c. ; they have the sliding centre and spring, and make a perfectly smooth cut.

\section{The Grass-Edging Knife.}

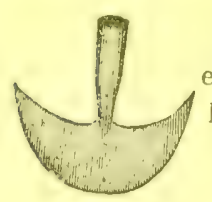

Fig. 94 is fitted to a straight handle, and used for paring the edges of grass bordering walks, \&c. ; also for cutting the out lines of sods, which may then be readily raised by the spade.

FIG. 94. 
Bryer or Bitu-Hooks.

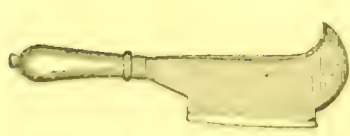

Fic: 1).

These are of various forms, though the one represented here is the kind most approved; they are used with either long or short handles, as circum. stances may require, and are very useful for trim. ming hedges, cutting brush, brambles, \&c.

\section{Garden-Rakrs.}

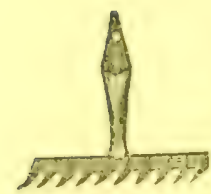

'These vary in the length and strength of their teeth, as well as in their number; they are used for covering seed, raking of weeds or cut grass, smoothing and pulverizing surfaces, \&c.

Fic. 96.

Tiue Grass Laivn Rake.

Fig 97 has teeth sharpened on both edges like lancets,

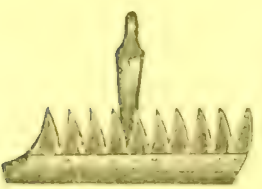
and is used for raking the grass in order to tear off the flower heads or buds of daisies, dandelions, and other

FIG. 9\%.

\section{Garden.Trowels.}

Fig. 98 is used to plant or take up for re-planting, herbaceous plants, very smal trees, roots, \&c.; they are also used for stirring the soil among tender plants in confined situations and loosening the roots.

Fiเ. 98 .

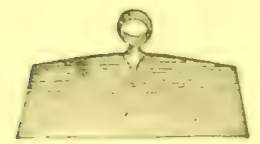

Fir., !n

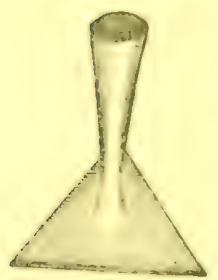

FIG. 102 .

\section{Girntiv-Hoks.}

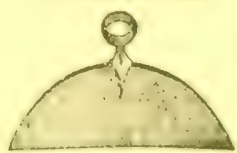

Iits; $1111 \%$.

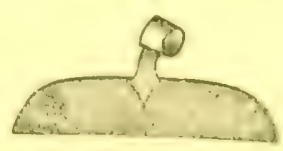

FIG. 101.

Fig. 99, Square Hoe, cast steel ; Fig. 100, Half-round Hoe, cast steel; Fig. 101, Turnip Hoe, cast steel; Fig. 102, Triangle Hoe, cast steel; Fig. 103, Forked-back Hoe, cast steel; Fig. 10., Pronged-back Hoe, cast steel.

\footnotetext{
FIG. 103. FIG, 104.
} 


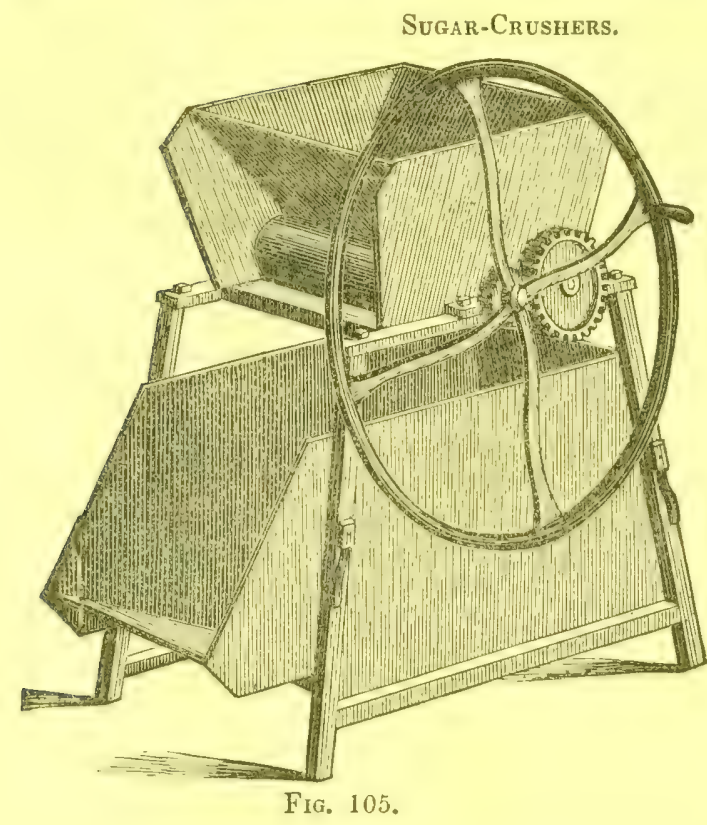

This machine 18 used by grocers and others, for crushing sugar as it is taken from the hogshead, preparatory to offering it for sale. The dampness of the botiom or sides of the cask is thus equalized, and the appearance of the sugar thereoy much improved. They are simple and easily kept in order, and are turned by hand. They are of various sizes, and will crush from 6 to 12 hogs. heads, or more, per day.

\section{Platform-Scales.}

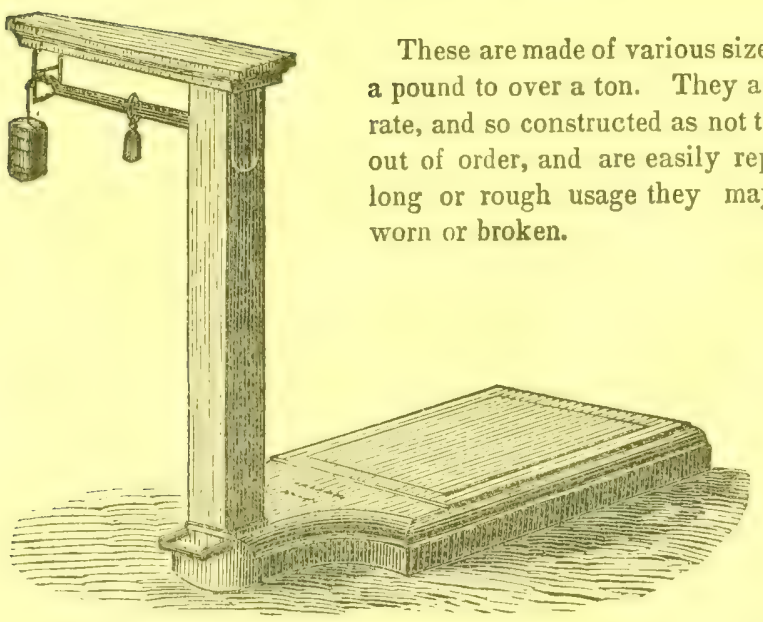

Fig. 106. 


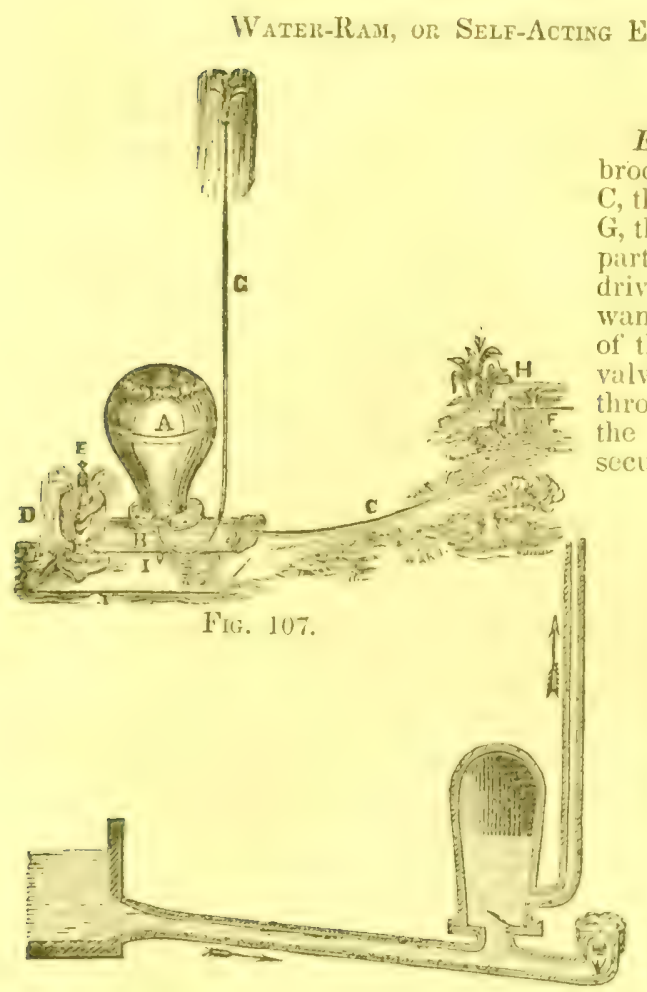

Explanation. - H is the brook, spring, or fountain; C, the supply, or drive pipe; $G$, the pipe which conveys at pirt of the water from the drive pipe to the place where wanted; $\boldsymbol{A}$, the air chamber of the ram; $\mathrm{E}$, top of brass valve; $D$, water wasting through the valve by which the power of the run is secured.

FIG. 108.

Wherever a large spring, or a limited but constant stream is at hand, by which a fall of four or five feet may be produced, by building a dam or otherwise, a considerable portion of the water of such a stream may be raised to a perpendicular height of more than 100 feet. by its own power. Thus a stream in a deep valley, or a river or brook, situated some distance below a point where it is desired to have a cistern or reservoir, may be made to raise itself hy one of these machines. From such a cistern or reservoir, the water may be conveyed to any part of the premises of a lower yard and applied to the purposes of irrigation, the watering of stock, the supply of manufactures, or for domestic or ornamental use. By this means, lawns may be kept fresh and green throngh the driest weather; fields and gardens may be irrigated, foun. tains be kept playing, and public buildings, hospitals, hotels, private dwellings, and manufactories, may be copiously supplied with water in their highest apartments.

We furnish these machines to order, of various sizes, and at a moderate cost. They will raise from 5 to 50 gallons per minute. 
Orders received, also, for any of the following articles, with competent engineer, if required, for fitting them up, viz. Cast-Iron Fountains, Figures and Shells, Fire-Engines, Double-acting Force-Pumps, Filtering-Machines, AirPumps, Wind-Mills, Water-Wheels, Leather-Hose and Hose Coupling-Screws. Lead-Pipe, Brass-Work, \&c.

Cast-Iron Fountain.

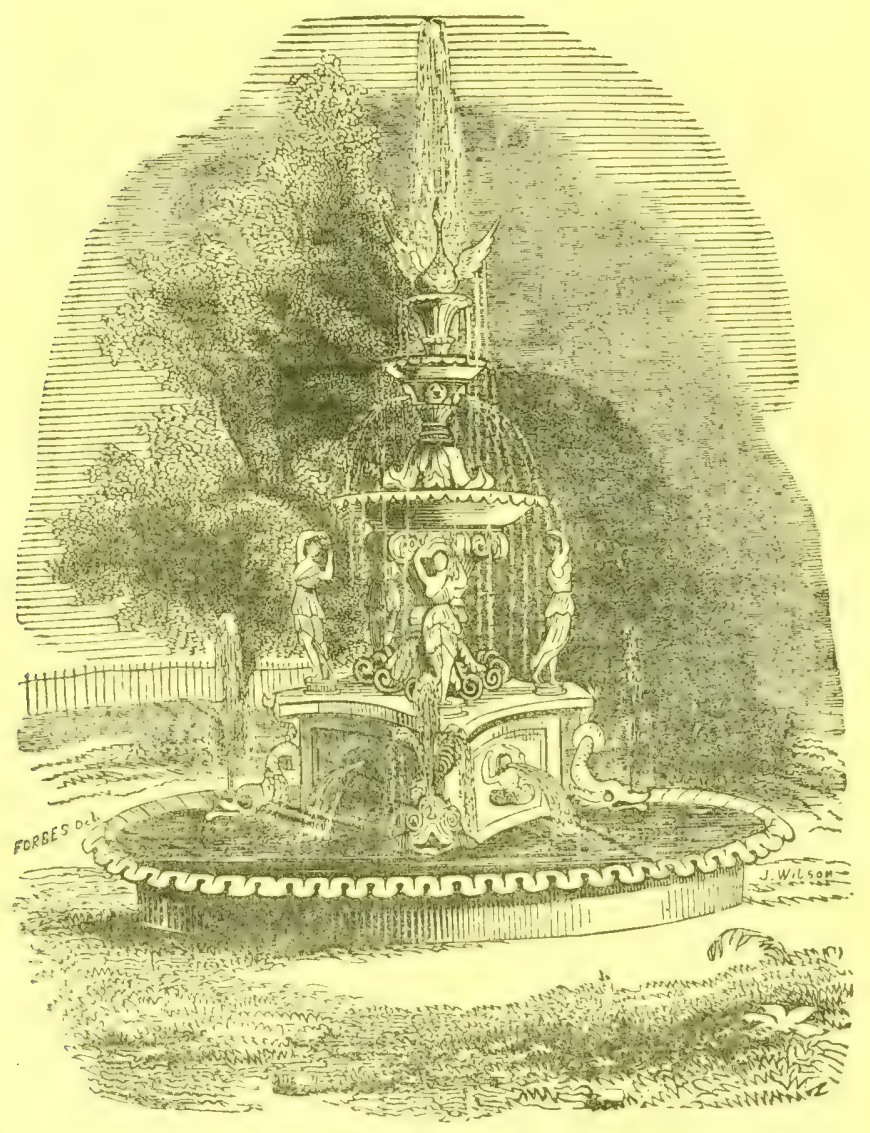

FIE. 109.

There are a great variety of the cast-iron fountains furnished us by the manufacturers, combining almost every style of rural and classic taste, all of whicn we can supply on demand, at the lowest prices. 


\section{T II E GARDE N.}

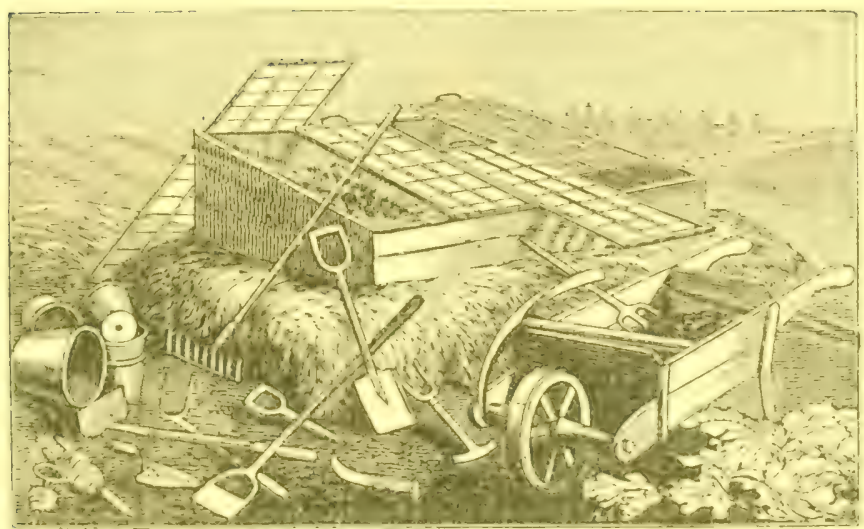

In garden culture, greater pains should be taken than in field culture, because the products there are required to be of superior quality; and it is desired to make the most of the land, to say nothing about the eye being gratified with its tidy appearance. It should be sheltered from cold winds, and have a southern or eastern aspect if possible; also, a warm, dry soil for all early vegetables. Later products may be put on a colder soil. The deeper the ground is stirred. and enriched, the better. One foot is the least depth that a good gardener will be satisfied with, and if he can turn up and enrich the soil to eighteen inches or two feet, so much the better. Indeed, with asparagus and some other products, the latter depth is absolutely necessary to produce a good crop.

\section{Sort.s.}

Stiff clays should generally be kept in grass or the small grains, for, owing to their adhesiveness, they are so difficult of cultivation that they will not pay for working them at the present prices of labor. If properly managed and occasionally inanured, their average yield of grass is good, and it does not run out as in most other soils. Loamy and sandy soils should be subject to a rotation of cropls.

The ground should always be thoroughly and deeply pulverized. In aldition to the use of the best common plows, this is best done with the sut soil plow, which loosens the substratum without turning it up to the sr face. 
Sub-soils are rarely so rich as surface soils; they should therefore be brought up and mixed with the surface soil no faster than they can be enriched and made equal to it. A rich subsoil may be advantageously turned up to any depth. In alluvial bottoms, when a depth of six inches or more of soil has been cultivated till it has become somewhat exhausted, by turning up an additional depth of fresh rich earth is thus brought to the cultivated surface, and is equivalent to a good manuring. Trench or deep plowing, under such cir. cumstances, is very beneficial.

\section{FIEID ARD CARDIN SEIDS,}

\section{Observations relative to Selection, Culture; \&c.}

In selecting our seeds we use the utmost care to ascertain, in the first place, whether they be true of their kind; and secondly, whether they are fresh and certain to generate; and thirdly, whether they be free from all foul seed. We, however, do not claim infallibility, and from being deceived ourselves, may occasionally be the innocent means of deceiving others. Whenever such a case occurs we beg to be apprised of it, and the party complaining shall be ensured redress.

Seeds often do not germinate in consequence of the extreme dryness or dampness of the ground; from excessive heat or cold; from being covered too deep or too shallow; sometimes they are burned up by coming in too close contact with hot manures; or the soil may be too poor; or they may be eaten up by under-ground insects; or if they escape these, as soon as the embryo bursts and before it can appear above ground, it may be destroyed by worms or flies frequently so minute that the naked eye cannot perceive them; or after coming up, they may be choked and destroyed by weeds. All these causes should be inquired into thoroughly before complaint is made; for it is more often other causes than fault of the seed, that prevent its germination and growth. Where there is any doubt upon the subject, a small quantity of seed should be bown in a flower-pot, and carefully guarded in a conservatory or some proper Hace, till a sufficient time has elapsed to prove whether it be good or bad.

Ce rTure of Roots.-All roots require a deep, rich, mellow, and sufficiently dry soil It should be worked at a time that will insure its being left finely pulverized. The use of long or unfermented manure is not objectionable, if it can be laid sufficiently deep in the furrow to be out of the way of subsequent tillage. The great supply of the nutritious gases afforded to the growing crop while it is undergoing decomposition, renders it a valuable manure.

Arтісноке (for the Garden).-The Large Globe is the best variety. It is propagated either from the seeds or roots. It requires a rich soil and ample room. Plant the seed early in the spring, three or four inches apart, in rows from one to one and a half feet apart. The next year, transplant the roots or offsets to beds highly manured, placing three or four roots in a circle of six inches, and these circles three or four feet apart. Protect during the winter by raising over them a mound or litter of light dry earth. 
Artichore, Jerusalem ( for the field).-This root is cultivated like the potato, in hills or drills. At the South and West, it is fed by turning swine on to the fields. A winter's supply of food for these animals is pasily pro. vided, and the crop thus fed off greatly enriches the land. This artichoke is considered one of the best of fertilizers, as it derives a large amount of its car. hon and nitrogen from the atmosphere. It should be cultivated extensively in well grown orchards. After the fruit is gathered, swine may be turned on. Their rooting is nearly as beneficial as plowing; they destroy, at the same time, nearly all the insects harboring round the trees, and the manure they leave is equivalent to a good top-dressing. Frost does not injure artichokes and they will propagate without replanting. They grow on the poorest land.

Asparagus.-There are several varieties of asparagus, but the difference mainly arises from the nature of the soil. On strong loamy land, the growth is more robust and the shoots more tender than on sandy soil. Early in the spring, soak the seed in warm water for 24 hours, then drill it thinly, in rows sufficiently wide to admit the hoe. When two years old, they may be transplanted into permanent beds. A convenient width for these is four feet, and the plants placed twelve inches apart in each direction. They should be planted at least four inches beneath the surface, well manured at the time, and annually thereafter. Salt, spread broadcast thickly over the beds, after forking them over early in the spring, adds to the growth of the plant, and makes it much sweeter and more delicate. A compost of guano and charcoal is also an excellent top-dressing,

Beans.-These may be planted in hills or drills. The former is somewhat more convenient for the field, as it admits of easier culture with light plows or cultivators. When land is in good condition, it is better to place the hills so near to each other, that only a first or second plowing can be performed. The spreading of the vines will prevent any subsequent cultivation. Hoeing when wet with rain or dew is said to rust them. The best bearers are the garden beans; and among these there are none better than the long white kidney. They are early ripe, sure and prolific bearers. Any good soil is suited to them, but it must be dry. They may be planted when there is no longer danger from frost. They are often planted among corn at the second hoeing, but the corn ought to be sufliciently thick to prevent the growth of any other crop.

BEET. - Pour boiling water on the seed, and let it stand afterwards at blood heat for two or three days at least, when it will be fit for sowing. Mix plazter, ashes, or fine dirt, with the seed before sowing, then plant with a seed sower, or sow by hand, four inches apart, in drills two and a half or three feet distance, and about one inch deep, and set the earth compactly over them. After the young plants make their appearance, stir the earth frequently with the horse plow or cultivator, and keep the weeds well cleaned out. But one plant should be left every six to eight inches in the drills, and if any are deficient, their places may be supplied by transplanting in a moist or wet day. They should be harvested before severe frosts set in, the tops trimmed off and 
laid in pits or in a cool cellar. The best kind for stock feeding, is the sugat beet, and it produces as large a crop as the mangel-wurzel. The long blood red, and orange turnip-root beets, are the best for the garden. These may be sown in drills one foot apart. Four pounds of good seed is enough for an acre.

BorEcole.-Under this head, we may have the dwarf-kale, which is an excellent green for winter and spring use, and being dwarf it is easily preserved during the severest weather; and the Scotch kale, which is sown in May and transplanted and treated as winter cabbage.

Broccolr. This produces heads like cauliflower in autumn. The large purple Cape appears to be the best adapted to our climate. Sow in seed-beds early, transplant into very rich ground when eight or twelve inches high, and manage generally as is usual with winter cabbage.

Brussers Sprouts - Are cultivated for the small heads which spring in considerable numbers from the main stem. They are much esteemed in some parts of Europe. Sow in seed-bed early in spring, and transplant and manage as with winter cabbage.

CABBAGE.-For the garden, sow the early sorts in a hot-bed, and transplant from two to three feet apart in a wet or cloudy day, as soon as the weather will permit, on well manured or rich land. For field-culture, sow the later and larger kinds of seed in beds, and transplant about the first of June, somewhat farther apart than in the garden, so as to admit the cultivator running between the rows.

Carrots. - These should be sown in soil similar to the beet, except that it requires to be somewhat lighter and looser than is essential to the beet. Soak the seed in warm water for a day or two, and then thoroughly mix it with plaster, ashes, or dirt, to break the little adhesive fibres, and allow of sowing easily. The drills may he two to two and a half feet apart, and the plants allowed to stand about eight inches apart in the drill, if of the largest kinds or if of the smaller, they may stand nearer. For the garden, sow in rows of nne foot apart. Frequent hoeing or stirring the ground, and thorough weeding, are essential subsequently. The white or Belgian carrot is the greatest producer at the least expense of soil, as it draws largely from the atmosphere for its support, and growing high out of the ground, it is easily harvested. It is not, however, as nutritious for stock, pound for pound, as the other kinds. The lung orange or red is a choice kind for the field. About two pounds of seed is required per acre.

Cauliflower. - Sow the early in hot-beds, and transplant into rich soil. The late to be treated like the Cape broccoli, which it resembles.

CeLery.-Sow in hot-beds, and transplant into a rich, moist place. This is a favorite salad.

Chervil.-This is also used as a salad. Sow in close drills in May.

CoRn-SALAD or VETTIKosT.-This is a small salad used throughout the wir 
ter and spring. Sow thickly in drills first of autumn, and cover lightly with straw on the first approach of severe weather.

InDian Cors. - This should be planted for ripening as soon as the spring frosts are over. The soil must be light, dry, and rich, to produce a good crop It is always best to soak the seed before planting, in a strong solution of saltpetre. This gives an early, vigorous growth, and prevents crows and other foragers from depredating on the fields. An absurd principle is adopted by sone farmers, to set up scare-crows, or kill of the birds visiting the fields. Even if they take some of the seed, they will probably more than make up for it, by the quantity of worms and bugs they will also destroy. But by soaking in saltpetre, or pouring into a barrel containing a bushel of seed, a quart or more of very hot tar, stirring the whole mass rapidly, every kernel will have become coated, and the plunderers after picking up a few will gladly give up the pillage, and betake themselves to an extermination of the rival enemies to the corn, the worms, bugs, and beetles.

Corn shoukl be planted on well plowed ground in leaving, with thrce to sir stalks in a hill, according to the kind of seed used, three to five feet apart, $\mathbf{s} 0$ as to admit of weeding and stirring the earth both ways with the plow or cultivator. For light land, even or level cultivation (not hilling) is best. The tops of the corn should never be cut off till the corn is nearly ripened; but in. stead of the top, when there is danger from frost, the whole stalk should be cut close to the ground as soon as the grain is thoroughly glazed. If shocked in the field in this state it will fully mature the grain and yield good fodder from the stalk. The Dutton, Brown, and other kinds of eight-rowed, large-eared, and early-maturing corn, are best for the Northern States; while the choicest varieties of the gourd seed are better and more productive for the warmer climate of the South and West. Sugar or sweet corn is the favorite for cultivating in the garden for table use.

Sowing corn for soiling or fodder has been adopted of late years This is done by sowing in drills, say eighteen inches or two feet apart, and quite thick in the rows; or broadcast, at the rate of three to four and a half bushels per acre. The best kind for soiling is the sweet corn, as its stalks are the sweetest, most juicy, and tender. Where it has taken well, and the season has proved favorable, an enormous quantity of fodder has thus been raised.

Broon-Cons-Should be planted on soil similar to the preceding, but somewhat later in the season, as a spring frost, which could be resisted by the greater harliness of Indian corn, might effectually destroy this plant. The rows should be three feet apart, and the hills about two feet distant from each other; fifteen to twenty ripe seeds should be sown in a hill, so as to ensure eight or ten good plants, to which number they should be thinned on a second weeding. Early and frequent stirring of the ground is essential.

Curled Cress or Pepper-Grass. - Used as a small salad. Sow very thick. ly in shallow drills, at short intervals throughout the season.

Cucumbers. - To obtain them early, plant the seed in' hot.bed, or in elevat- 
eu hills, well manured with rotten horse-dung, and covered with glazed frames. For later use, they should occupy rich, light, and warm soil, well mixed with manure; or a good shovelful or more may be put into each hill. Plant in hills about four feet apart each way, elevating the hills a little above the level of the ground. Put in eight or ten seeds into each hill, and cover them half an inch deep with fine dirt, and as in all other planting, press the earth a little over the seeds with the back of the hoe. When the plarits are up, examine them closely, as they are frequently attacked by the yellow bug, or fly. To prevent this, take soot, sifted ashes, and ground plaster, equal parts of each, well mixed together, and dust the plants with it. If the plants are dry, sprinkle them with water before you dust them. Keep the ground loose and clear of weeds, and in dry weather water your plants freely. After they have attained a vigorous growth, and the danger from insects is over, they may be thinned, leaving two or three of the most thrifty in the hill. Those intended for pickling, may be planted later. The cultivation and management of these is the same as the others, excepting that the hills should be at least five feet apart each way. Nip off the first runner bud of cucumbers and melons, and they will become more stocky and fruitful.

EgG-PLANT.- Sow in hot-bed or other protected place, very early in the spring, and transplant into rich ground, two to three feet apart. The seed does not vegetate freely, and repeated sowings are sometimes necessary.

Exprve.-Sow from May to July in shallow drills; thin out the plants to stand eight to ten inches apart; tie up to blanch as needed.

SEA KAIE,-Plant in hills two feet apart. It is forced into grow th in the spring, blanched, and used as asparagus.

LEEK.-This is so hardy as to endure the extremes of heat and cold without mjury. Sow early in drills, eighteen inches apart, and thin the plants so that they may be six inches apart.

Letruce.-This requires a mellow soil. It should be sown as early in the spring as possible, or it may be sown late in the fall for early use the following spring. 'To obtain a constant and regular supply throughout the season, it should be put in every month from March to September. It nay be sown broadcast, moderately thin, or in rows from twelve to eighteen inches distant, according to the usual size of the different kinds. Rake in the seed lightly with a fine tooth garden-rake. When the plants are up, stir the ground lightly when it is dry, and clear out the weeds. The most tender salad is produced when allowed to grow up thick. This may be early and continually thinned for use. Those intended for large heads should stand eight or ten inches apart; the hardy kinds, such as the large green head, ice cross, and biown Dutch, may be sown in September, and covered with straw at the approach of severe weather. Any kind may be sown in hot-bed in March, and transplanted in the open ground at the proper season.

Mielons.-Treat the same as cucumbers, except planting wider apart, say ve to seven feet. 
Mustard.-The white and broad leaf kinds are excellent for salad or greens. They should be sown very early in the spring, in a rich, warm soil, in shatlow drills, ten inches apart, and kept clear from weeds. After the crop is off, the ground may be planted with other crops.

For grinding, the brown mustard seed is the best, and may be sown broad cast or in drills, and kept cleau from weeds. This is now cultivated extensively as a field crop, by sowing it broadcast or in drills from one foot to eighteen inches apart. How it when ripe, and cure it like grain or hay, and thrash out the seed in a grain thrasher. It yields from ten to fifteen bushels per acre. It is a great exhauster of the land when grown for seeil, and requires a rich soil. It is sometimes plowed in green to enrich the land. When sown in drills, from one and a half to two quarts of seed are enough per acre; broadcast, it requires four quarts per acre.

Nasturtium.-The flowers and young leaves are used as a salad. The sced-pods are gathered while green and tender, and pickled.

OkRA.-This is a wholesome vegetable and much used in soups. I'lant in May or June, in hills two or three feet apart, allowing two or three plants 10 stand in a hill. The seed is liable to rot in the ground, and should be put in thickly to secure the requisite quantity of plants. Very rich ground is required for this vegetable.

PARSLEY - Sow early in the spring, in rows or beds. If the seed is soaked in warm water some hours immediately before sowing, it will vegetate more speedily. When sown dry it will sometimes lie in the ground two or three weeks before it vegetates.

Parsnip.-This root is among the most valuable raised for farm stock. It requires deep, rich, loose soil, and may be sown at about the same listance at carrots. The seed need not be soaked before sowing; but it should be put in the ground early, while the ground is wet, which will ensure its immediate vegetation. Unlike all other cultivated roots, except the articholic, the parsnip may remain in the ground throughout the winter, without injury from frost; but care is requisite for the removal of all standing water, or lecay wiil inevitably follow. About two pounds of seed are required per acre.

PEas.-These are adapted to almost any dry soil; yet they will give a much greater yield on rich land. Fresh manure is not good for either peas or beans. They will bear a much heavier soil than the bean, good clays heing highly favorable to their growth. The fields intended for peas should be prepared by fall plowing, and the seed may be sown, as soon as the land is sufficuently settled in the spring after the heavy frosts, either hroadcast or in trills, and narrowed or plowed in two or three inches deep. In the latter case, they will admit of light plowing or harrowing immediately after they are up, by which weeds will be exterminated and the growth of the crop promoted. Where the soil is adapted to them, and the seed takes well, broadcast sowing is equally efficient in preventing weeds, as their vigorous growth effectually overshadows and keeps them in subjection The best kind for field sowing is the grass pea 
and the marrow-fat for garden-culture. Earlier kinds should be selected in part, for the garden. Sow at the rate of two to four bushels per acre.

PePper.-Sow in drills, on a warm border, late in the spring or early in summer, and thin them to stand sixteen to eighteen inches apart. Or they may be sown early in the season, in a frame or flower-pot, and transplanted.

Potatoes. - This root is the product of almost every soil, although dry, rich land is best suited to them. A sod turned over in the preceding autumn, so as to become well rotted in the spring, is perhaps the best suited to give a fair yield, and at the same time a fine, healthy, well matured crop. They may be planted in hills or drills. Whole potatoes, of a medium size, are better for planting than small, or large cut ones. They should be well hilled up in hoeing. The hills may be about three or three and a half feet apart; or if in drills, they may be three and a half feet asunder, and the potatoes placed about ten inches apart. There are a variety of choice potatoes, which are popular times in different parts of the country, and which, from the introduction of ew and favorite varieties, or the older ones becoming poor bearers, or from other causes, fall into disuse. Among the best of the present time may be mentioned the kidney, the pink-eye, \&c. It requires from twelve to twenty bushels of seed, for planting an acre.

Pumpkins.-This is a valuable field crop for fall and early winter-feeding, for cattle, sheep, and swine. It is usually planted among corn and potatoes, which is a good practice. But it may be advantageously grown by itself on a rich, dry, well pulverized soil, planting in hills, at a distance of six to seven feet apart each way. Most of the cultivation may be done with the cultiva. tor. The large yellow pumpkin is the best

RADISH.- These may be sown at all times in a warm soil. The land should be well manured, deeply dug, and raked free from clods and stones. For a succession of crops, sow once in two weeks.

Rhubarb.-This is cultivated for the leaf stalk, which possesses an agreeable acidity, and resembles the gooseberry when made into pies or tarts; and it is an excelleut substitute for it, as it is fit for use before green fruit can be had. It is propagated from the roots, which, in deep mellow soil, give an immediate and large return.

Ruta Baga or Swedish Turnip.-This may be sown on land prepared similarly to beets, either broadcast or in drills. The former method is preferable in one respect, as it gives a much larger supply of food to the turnip beetle or fly, which may still leave enough for the farmer after it has eaten its fill. Early sowing is best, as it insures a good crop of large roots, or if it is cut of by drought or the fly, it leaves sufficient time for resowing. Soaking the seec in the most offensive curriers' oil for two or three days, and then rolling in plaster, is a help to the young plant, and they both assist its rapid growth, and the oil is nauseating to the insects in its first tender leaves, which are most li- 
able to destruction. About one and a half pounds of seed is required per acre.

Salsify or Vegetable Oyster. - The roots are boiled like carrots, as a regetable dish; or after being par-boiled, made into cakes, with paste, and fried like oysters, which they closely resemble in flavor. Cultivated in all respects like the carrot.

SorREL. - The garden sorrel is used as a salad. Sow in June, in drills, and thin the plants to twelve inches apart.

Spinach.-This may be sown at every season. It produces thick, succulent leaves of a large size. It may be sown either broadcast or in drills. For spring or summer use, sow as early as the ground can be tilled, and afterwards at short intervals. For winter and early spring use, sow middle and last of autumn. The latter sowing will need a sprinkling of straw or long manure on the arrival of cold weather. The ground cannot be too rich for spinach, and the stronger it is, the more succulent will be the leaves, and of course the more delicate and tender.

Squasi.-Cultivate the same as cucumbers and melons.

Tossato - For early use, sow in hot-beds and transplant into warm soil, setting the plants in rows three or four feet apart, which should be trained on poles.

IV hite or Englisir TURnip.-This crop is raised most successfully on newly cleared land, which is well coated with ashes and charred vegetable matter; or on a fresh sod which has been long in grass and turned over the last of May or early in June, and on which sheep have been folded till they have covered it well with manure. Good seed sown on this, after thorough replowing and harrowing till it is sufficiently mellow, at the rate of one and a half pounds per acre, and brushed in, will generally insure a good crop.

For further particulars on the culture of grass, grain, and roots, we refer to the American Agriculturist, and Compend of American Agriculture, where the most minute directions may be found for nearly all these different kinds of crops.

\section{GRASTES AND CIOVERS.}

There are many kinds of plants that belong to the clover family, such as the scarlet, yel!ow, and Bokhara clovers, sainfoin, trefoil, \&c.; but for various reasons, which we have not space to enumerate here, they have not flourished well in the United States, and we forbear encumbering our pages with them. The same remarks will hold in respect to bent grass, rib grass, \&c., \&c. We have either tried on our own farm, or seen tried by our friends, nearly all European grasses and clovers, and the result is, that they are not equal to those we mention below, and our farmers, therefore, have nearly abandoned their 
culture. We believe that some of the indigenous gzasses of America may be profitably cultivated, and we recommend experimenting with them in preference to European grasses, already so often tried and found wanting.

Blue Grass.-This is, properly, the Smooth-Stalked, June, or Green.Grass of the Northern States, and is deemed invaluable at the South-west, yielding a luxu. riant winter forage, which is cropped by the stock on the ground. It is a valu. able pasture grass at the North, being hardy and self-propagating, and with the white clover, spontaneously filling up every vacant space of waste ground in our good clay lands. But as a meatow grass, it is lightly esteemed, coming to maturity some weeks before the Timothy or clover, and by the time they are fit to cut, yielding only a small quantity of withered grass. Like the white clover, it ripens and sheds its seed, so as to give a prolific growth of fresh plants for the fall and spring feed. Few plants equal this and the white clover for fattening qualities, or the production of milk. Both yield a superior ouality and a large quantity of butter. When cut with white clover for hay, it should be housed as green as possible, and well salted. This grass is very desirable for lawns, as it grows fine and thick, and the turf is firm and elastic under the feet. It should be sown at the rate of ten to fifteen pounds per acre, in the autumn or winter at the South, and early in the spring at the North. Top-dress with fine compost, guano, or ashes and lime.

RED CLOVER. - This is one of the most important crops in the United States. It grows readily on almost every soil, from Maine to Texas; and under proper treatment, almost everywhere yields profitable returns. By large numbers of farmers, especially in New York, New Jersey, and Pennsylvania, it is used extensively as a fertilizer in their rotation for wheat, for which nothing is better adapted. It also affords one of the most profitable crops of hay. For this purpose it is usually raised in connextion with Timothy, a practice which is objectionable, on account of its maturity for the scythe, being some time earlier than this grass. It does well sown with orchard grass, as the two ripen about the same time. All soils are suited to it, if dry and fertile. It may be sown in the autumn or winter at the South; at the North with winter wheat or rye, when the snow is just disappearing in the spring, and while the earth is still thrown up by the effects of frost, or as early thereafter as possible. No subsequent harrowing is then necessary. It may also be sown with oats or barley after the latter have been harrowed in. It should be cut before the bulk of the blossoms are turned brown, and after lying in the swath until wilted, tumed over without sjreadng, raked and cocked the same day; and when sufficiently cured in the cock, put in store, with the addition of a peck to half a bushel of salt to every ton. There are several kinds of red clover; the large or northern, the meadow, and the dwarf. The two former are usually cultivated. Clover, and all other crops, when sown upon light or sandy lands, are greally improved by the use of the roller. From eight to sixteen pounds of good seed is required for an acre, more being necessary on stiff or old soils than on new and lighter ones.

White Clover.--This is a valuable herbage for pastures, but does not grov 
to a sufticient size for profitable hay. Clays and calcareous soils are best allapted to it, and on these, if in good condition, it grows spontineously and in great abundance. Plaster, with a reasonable degree of fertility, will always insure a luxuriant growth of the clovers, often bringing them into existence where their presence had scarcely before been noticed. Sow from four to eight pounds per acre.

LUCERNE.-This is cultivated to considerable extent in the neighborhood of

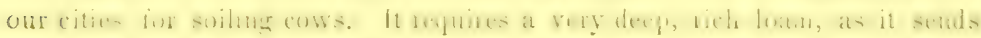
down its long tap roots to a depth of 2 to 5 feet. It must be kept clear of weeds the first year, after which it completely covers the ground. It may be cut several times in the course of the season, and yields a large quantity of fodder, somewhat inferior in its nutritive qualities to the red clover. Plaster, or bones in considerable quantities, ground and scattered broadcast, and other manures, are essential to its continued productiveness on the same land. It requires from ten to fittecn $l$ bs. of seed to the acre, if sown broadcast, or two thirds of the quantity if sown in drills nime inches apart.

Orchird-Grass.-Orchard-Grass of the United States, is what is called rough cocks-foot in England. It comes forward earlier than any other grass in the spring, and produces most abundant crops in quick succession, yielding several large cuttings of excellent hay in one season, and furnishing a great quantity of nutritive pasturage. It requires a dry and good soil, and should be cut before it ripens, or closely fed, to secure its full value. Sow at the rate of one and a half to two bushels peracre, for if the seed is not sown thick, it will come up in tufts. It is important that this grass should cover all the land.

Herds-Grass or lied-Top.-This is a valuable grass for very moist soils, yielding a large return of good liay. It is cultivated in the same manner as Timothy, but requires a moister soil. In New England, a variety of this species is usually known by the name of hed Top. The quantity of seed required to sow an acre is from 12 to 16 quarts.

RaY-Grass-Perennial ray-grass or rye-grass, yields very realily and with comparatively little trouble, an abundance of sound, healthy seed, and is certain in its growth. It starts early in the spring, and is much relished by all kinds of stock. It answers equally well for a course of mowing and pasturing for two, three, or seven years

There is a variety of this plant known by the name of "Italian Rye-Grass," of only two years' luration, which is almost universally sown in Eugland and some other parts of Europe, either with or without clover, among grain-crops, with the view of obtaining a crop of hay the second year. It attains a greater height, and produces a longer, broader spike of flowers than the peremnial ryegrass; and the produce in hay is considered greater than that of any other biennial grass, equally palatable to cattle. The quantity of seed employed in Eowing an acre, is from 10 to $16 \mathrm{lbs}$.

Tald Oat-Grass. - In the Middle States, particularly in Delaware, this is one of the best grasses for early soiling. It grows rapidly and produces a con 
stant succession of luxuriant fodder, whether cut or fed on the ground. A stiff clay, as well as other soils, is suited to it. It should be sown in the spring, either by itself or on winter or spring grain. It should be fed green, as it is too coarse and dry when cured to make good hay. Sow from 12 to 16 quarts per acre.

Timothy or Herds-Grass.-This is also called foxtail, and meadow-cat's tail. It is among the best grasses for hay in the northern parts of the United States and the Canarlas. Good clays or loamy lands are best suited for it. Unless sown late in the season, it will not require harrowing, the rains planting it with sufficient depth where the surface is light or well mellowed with the harrow. It should be suffered to remain till the seed is rather past the milk, and getting into the dough, when it may be cut, and in this state much of the seed will germinate. Enough of the seed is thus scattered upon the ground, to renew and keep the permanent meadows in high condition as to productiveness. It is suited either to a moist or dry soil. If sown with clover, at the proper season, 8 quarts of seed, with 6 to $10 \mathrm{lbs}$. of clover, on a well pulverized surface, will give a good coating of grass; but on a stiffer soil, or when an immediate thick growth is desired to keep all weeds down, this quantity may be nearly doubled. Although it yields little or no after-math, when cut late, yet Timothy makes a rich productive pasture. It may be sown in August or September, or early in the spring, at the rate of 12 to 16 quarts per acre

\section{FIRTITERS。}

We shall treat only of such fertilizers as are usually kept on sale; and in doing this, it is impossible to give any thing more than brief, general directions as climate, the nature of soil, the crop to be raised, and many other particulars must be taken into consideration, in their proper application. Great wasto is often made in applying manures. For example, bone-dust is sometimes applied where there may already be sufficient of the phosphates in the land; lime, where the soil is full of it; ashes, on new and rich land, \&c., \&c. In such cases as these, manures have little or no effect for a time, or until crops bave partially exhausted them. Barn-yard manure, peat, and muck, are often applied to wheat and other small grain crops, when they only serve to injure the grain, by forcing a large growth of straw. Grass, corn, roots, and some other crops, may be successfully raised with manures of almost any kind or quantity; and as a general rule, the small grains should succeed these crops, at which time, ashes, plaster, bones, or lime may be applied; and if the soil be voor, $\mathrm{a}$ top dressing of guano, rotted barn-yard manure, or composts of fish with peat and muck, may be added. For minute descriptions on all these points, we would again refer to the American Agricultuist and Compend of American Agriculture.

WOOD AsHES. - These may be used leached or unleached, with good effect at all seasons, and on all kinds of soils, though they best suit light sandy 
or gravelly soils. From 10 to 70 bushels per acre are applied. Grass and turnips are most benefited by them, and they have a marked effect on corn, wheat, and other small grains. They should be spread on grass lands early in the spring, or just after mowing, -around the stalks of corn after the first hoeing, spread broadcast over the turnip crop after sowing, or be brushed in with the seed, or applied in the same way to wheat, rye, and other small grains, in the fall or spring. Anthracite coal ashes are also found to have a markel effect on graiss and corn.

Bowe. Dust.-This may be applied like ashes, except in less quantities; ten to thirty bushels per acre is sufficient for a single application. Its effect on Indian corn is not so good as ashes. It best suits grass, wheat, and turnips.

Cinarcoal Dust.--This also may be applied like ashes, but in larger quantity, from twenty to two hundred bushels per acre. It absorbs moisture, ammonia, and other gases from the atmosphere, and is therefore particularly valuable on light soils. Keep it as near the surface as possible. It is an admirable mixture in composts of all kinds, especially such as abound in putrescent manures. It arrests and holds the ammonia contained in them, and removes all unpleasant smell.

Guaxo.-Caution in application.-Place the guano so that it will not touch the young roots, or stalks of corn, potatoes, cabbages, tobacco, sugar cane, cotton, or any plant that has but one stem; as it is so powerful that the smallest portion injures the plants, if it comes in contact with them before its strength has been diffused through the soil, by rains or dews. With grass and small grains, this caution is not as important, as other shoots from the roots will immediately supply the place of those killed.

Preparation.-Before using guano, pass it through a fine sieve, and all lumps remaining, break up, and these pass through the sieve. Then take at least four times its bulk of mold, or light loamy soil, and pass this through a coarser sieve, and mix it in layers with the guano. Let this complost lie a few daysseveral weeks would be better-then turn it over and mix well together, and it is fit for use. Some prefer adding the guano to ten or twenty times its bulk of soil for a compost, without sifting it, but mix them together in alternate layers as well as it can be done with a shovel. Sifting, however, is best, as it is done so much more evenly. Sawdust, spent tan-bark, peat, \&c., are good materials with which to mix guano; but charcoal is better than either, as it absorbs the ammonia, and is in itself an excellent manure. When convenient to be obtained, plaster of Paris ought to be used in the compost, at the rate of thirty to fifty pounds for every one hundred pounds of guano; it acts in the same way as charcoal. Lime and ashes must be avoided in composts, as they rapidly expel the ammonia, the most valuable part of the guano. Nuck, if possible, should not be used for the compost, as it is ton moist and tenacious to form a proper mixture. The same objection holds against clay or any tenacious soil. Yet, if there be no other soil at hand, muck or clay may be thoroughly dried and pulverized, and then used. Guano should not be mixed with 
farn-yard manures, nor indeed with any moist substance, as these cause it to unlergo the decomposition requisite to promote vegetation. The compost should be mule under cover, unless the weather be dry.

Quantity applied per Acre.-This depends upon the kind of soil and its condition, and the kind of crop to be grown. From two hundred and fifty to four humired pounds of guano per acre, is the safest quantity to apply. It acts quickest in a light sanly soil or loam, and is excellent to start crops on cold. moist land. It hastens the ripening of crops on all kinds of soil.

Guano should be spread broadcast upon grass lands, early in the spring, and directly after mowing; and on grain, early in the spring, or in the autumn directly after being sown. When applied to corn, either pure or in compost, a tablespoonful or so may be put roundeach hill, and a little dirt thrown over, and then drop the seed, or it may be hoed in round the corn the first time hoeing Apply it in the same way to peas, beans, potatoes, and other root crops, melons, sc.

Steeps and Liquids.-For one pound of guano, use ten to twenty gallons of water; or at the same rate for a smaller proportion. Stir it well and cover over the vessel tight, so as to prevent the escape of the ammonia, and let it remain from one to three days before being used. Water around (not upon) the plants as occasion may require. If the liquid touches the plant, or its leaves, it is liable to burn it. Previous to watering, stir the earth well around the plant. Corn and other seeds may be steeped in this liquid, from three to twenty-four hours belore sowing. It then comes up unusually quickly, and grows rapidly.

Lime.-This may be applied at any season, at the rate of twenty to twe hundred bushels per acre; but moderate and more frequent doses are preferable. Lilise charcoal, it does best near the surface, and in other respects may be applied like it. It best suits a clayey or loamy soil; its efficacy on light sands and gravel, unless with the addition of manures or vegetable matters, is much doubted. Lime is easily kept in large heaps in the open air, by throwing a little water on the top, which slakes sufficient to make a fine smooth crust over the whole. This soon dries hard, and forms a roof impervious to the rain. When the lime is to be used, the heap is broken into near its base, and whatever is wanted is taken out, and another crust is formed over this broken part, in the same way as above. Lime is frequently impure, and an analysis of it should be required before purchasing. About thirty-three bushels go to the ton.

Plaster of Paris. - Sow this broadcast upon grass or grain, early in the spring, at the rate of two or three bushels per acre. It requires to be sown early, so as to have the benefit of moisture, and to ensure its decomposition. It best suits clover and the broad leaved plants, and is very good for potatoes and turnips. On corn, grass, and the smaller grains, it has a good effect.

Poudretre.-This is an excellent manure to start corn and other products, and give them a quick growth, but its effect in small quantities is not lasting; a second dose, therefore, ought to be added at the second time hoeing. Two to 
five barrels are enough for one acre. For corn, put one gill into the hill, over or under the seed, when planted. Potatoes should have two gills per hill, and other crops in proportion. For soaking seeds, dissolve in the proportion of one quart of poudrette thoroughly in a gallon of water, to an extent sufficient for the purpose requirel, and then soak the grain or seed in the solution. The soakirg must take place immediately before planting or sowing. By this operation, the com, grain, or other seels, will start sooner, be stronger, and less iiable to attach from woms or birls. But if kept in the solution too long it may injure the greminating prineiple of the grain or seed. After it comes out of the liquid, the seed may be rolled in ashes, plaster, or sand, to separate it. Every farmer may make his own poudrette by mixing the freces with peat or muck, or by drying it with charcoal dust, or plaster of Paris. Either of these gubstances takes away all unpleasant smell.

SALT.-This may be used at the rate of five to thirty bushels per acre. It is inoperative applied near the seashore, where salt water or spray is already in excess on the land; but on all other lands not already fully supplied with it, it is beneficial. It can be sown broalcast or incorporated in the compost heap. Mixed with lime and its compounds, it undergoes decomposition, producing a variety of new combinations, most of which have a strong attraction for moisture. Salt and lime prodnce vegetable decay quicker than salt alone. W'ith plaster and lime, it will supply sola and sulphuric acid, and their various compounds, cheaper than any other materials. Applied at the rate of ten bushels per acre to gritss and regetables, it makes them much more productive, sweeter, and more nutritious. We recommend its use, wherever salt can be cheaply obtained. We have seen thousands of gallons of fish and other brine throw maway in our towns and cities, which is invaluable for adding to the manure heap.

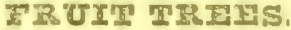

Before planting an orchard, the ground should be thoroughly subsoiled or trench plowed, to the depth of eirhteen inches or two feet. 'This is always done in Europe,

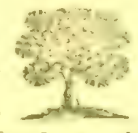

but seldom thought of in the United States; and yet we consider it the first and most important operation in the preparation of ground for an orchard, unless it be so rocky as to render this impossible.

TRARSPLANTING--It is frequently the case, that a tree which has received all the care and attention which can be bestowed upon it by the most experienced nurseryman, is transplanted to a soil of very inferior character, and being thus siunted in its growth, is the frequent cause of dissatisfaction to the purchaser. The planter should therefore bear in mind that, with the exception of very fertile alluvial bottoms, it is difficult for the soil in which a tree is planted, to be two rich, and that the rapidity of its growth, and its subsequent productiveness. 
are very much influenced by the proportion of fertilizing matter contained in the soil.

After the trees are set out, the ground should be well cultivated, and if a poor soil, as highly manured as the means of the cultivator will admit. It is impossible for a tree to flourish as it should, when the roots are surrounded and covered with a thick sod. When the tree is isolated, as in a garden or lawn, a rich compost of earth and manure should be dug in around it, care being taken that no unmixed manure be allowed to come in contact with the roots. The ground about them should be kept mellow until the tree is of larga size; and it would also be well to dig in a portion of manure about the roots every spring.

Many of the most experienced cultivators regard the autumn, immediately after the first hard frost has arrested the growth, as the best season for transplanting every variety of trees but evergreens, which should be planted in the spring. Where, however, it is not convenient for the cultivator to give them attention in the fall, deciduous trees may be deferred until spring. In sections where the cold is somewhat severe, as on the Western lakes, and in some parts of New England, it is more safe to plant the stone fruits and pears in the spring; and if they are imported in the fall, to keep them in a dry cellar until spring.

The reason for the preference for the autumn is obvious. When trees are transplanted at that season, the earth during the winter becomes well settled about the roots, and they are ready to throw out fibres in the spring. The spring is preferred for evergreens, for the reason that, unlike deciduous trees, they maintain a less torpid vitality during winter, and need sustenance from the greater activity of their roots; and experience has shown, that they succeed best when thus planted. When a tree is removed, great care should be taken to preserve the roots uninjured and entire; if this precaution is omitted, the top should be lessened in proportion to the diminution of the roots.

When the tree has been some time out of the ground, it is well to immerse the bodies and roots in water for twenty-four hours; this will much benefit it, and advance its vegetation. The holes for receiving them should be sufficiently large to admit the roots without crowding or bending,--from three to six feet in diameter, and from one to two feet deep, according to the size of the trees. The subsoil should be entirely removed to this depth, and its place filled with rich mould, well combined with compost or fermented manure. All bruised or broken roots should be shortened and smoothly pared with a knife. Let a person hold the tree upright, while the operator pulverizes the earth, and scatters it among the roots. Let the tree be shaken gently while this is done, and the earth be carefully filled in around every root, even the smallest fibre, for it is important that the soil should come in contact with every portion of the roots. When the hole is three quarters filled, pour in a few gallons of water, according to its size, and after it has settled away fill up the hole, pressing the earth around the tree with the foot. Earth watered in this way, will retain its 
humidity a long time, while water poured on the surface, after the hole is filled, is very injurious, causing the top of the soil to bake to such a degree as to prevent the access of air and moisture, both of which are highly essential to the growth of the tree. When the weather is very dry, put straw, hay, leaves, or even fine brush, if nothing else is to be had, around the bodies of the newly tansplanted trees, to retain the moisture. This is infinitely better than watering them. One of the most universal and fatal errors in planting trees is placing them too deep; we have known many fine and thrifty trees die from this cause. They should not be planted more than an inch deeper than they stood in the nursery, and if the frust is likely to heave them the first winter, a small mound can be heaped about the stem, to be removed again in the spring.

In attending to the preceding suggestions, we feel assured that the cultivator will be amply repaid for any extra trouble or expense, by the consequent increased growth, beauty, or productiveness of the tree.

\section{SOIIS PROPER FOR DIFFERENT KINDS OF FRUIT.}

The Apple.-This will succeed on almost any soil not too wet; a rich gravelly loam will, however, ensure the finest trees and fruit. Before planting, the ground should be subsoiled and well cultivated with corn or potatoes, and enriched, if necessiry, with a good quantity of manure. After the trees are planted, the orchard should be kept in cultivation for some years; and even after the trees become large and are in full bearing condition, the ground should not be kept in grass more than three or four years successively. Where there is leisure, it is a good plan to thin out the fruit when the crop is too abundant.

The Cherry.-This does best in a dry, rich soil, but bears abundantly even in stiff clays, when fertile and well drained.

Tre PEar.-This succeeds best on a rich, clayey loam, with a gravelly subsoil, but will grow and bear fruit on a poor soil, provided it is not too wet. A heavy clay soil should always be avoided, unless well drained.

The Plum. - A clay soil well drained, or rich loam, best suits the plum.

The Peach. $-\Lambda$ fertile sandy or light gravelly soil, is decidedly the best for the peach, though we have seen it flourish very well in a warm climate in clay soils, where no surface water could remain to their injury.

Pruning and Tranning.-All trees require more or less pruning. With young trees the knife is required to form a symmetrical head, to induce luxuriance of growth, and to cause early fruit bearing. Bearing trees in orchards, also require frequent pruning, to relieve the tree of all branches which are weak and crowd upon others, or uselessly consume the nourishment afforded by the root. It is also frequently required to check too great a luxuriance of growth, which often induces disease and seriously affects the longevity of the tree. Care and judgment, however, are necessary, and there may be often 
danger of too much pruning. When a tree is healthy, produces well, not too much crowded in its branches, and free from suckers on its boughs, il will in general require very little pruning. No suckers should be allowed to grow from the root, as they divert a material portion of the sap from the branches. There is much difference of opinion respecting the proper season for pruning, but our experience is that the early part of summer is the best; the sap being then in full flow, the wounded part quickly heals over, while in winter, the branch to which the knife has been applied, will be frequently found dead several inches below the wound.

Pruning, to induce early fruit bearing, may be advantageously practised when the grow th is so luxuriant that few or no blossom buds are formed. In this case, the extremities of the twigs should be shortened, and the sap being accumulated in a smaller portion of wood, forms fruit buds. The most effective mode of pruning, however, is applied to the roots. For this purpose dig a trench, early in November, around the fruit trees to be root-pruned, then cut off the roots with a sharp spade or knife made for the purpose, and apply manure. By continuing this practice every year, early fruitfulness is secured and the trees are brought into so compact a shape, that, being planted five to eight feet aprart, a sort of miniature orchard may be formed on a comparatively small piece of ground.

The quenouille mode of pruning and bending down of the limbs is practised in France and Belgium with much success. By it the circulation is impeded, nutritious matter accumulates, and flower buds are formed. The branches are bent down and tied below the horizontal line any time during summer, while the shoots are flexible, and after being thus confined a short time, they retain this pendent position. This is a most certain mode of inducing fruitfulness, but, though ornamental, is a somewhat troublesome form of tree. In Great Britain, and in some parts of the continent, where they have not the heat of our summers, fruit trees are trained, as espaliers, either upon a trellis or upo: walls, and it is no uncommon thing to see large gardens divided into numerous small compartments by brick walls, on which are trained a variety of fruit trees. In our fine climate this is unnecessary, and nearly all trees will succeed well as standards.

Where the curculio abounds, the farmer or gardener may advantageously cover all his stone walls or wooden fences with plums, peaches, apricots, or nectarines. When trees are planted thus against a wall or fence, it is well to have them a year old, and to retain the branches either horizontully, or in the fan mode, in which the branches are made to radiate from the root, as a common centre.

Fruit trees vary so much in different latitudes, that it would be of little use to give a select list; we refer therefore to the catalogues of the Nurserymen for this, as well as many other things we are obliged to omit for want of space. For the same reason we cannot treat of other fruits, the apricot, nectarine, fig, raspberry, gooseberry, currant, strawberry, \&c., \&c. 


\section{ORDERS FOR FRUIT TREES}

It is very desirable that all orders should be received very early in the sea. son, that we may have as much notice as possible, and send the trees to their destination at an early period after the opening of the season of trans. planting. For want of care on this head, many nolers arrive when it is no longer safe to take up trees, and they are necessarily left over until the next season. We would urge upon the attention of Southern and Western purchasers, the great importance of sending their orders as early as August or September. In the spring, vegetation is often far advanced at the South and IV est, hefore the frost will allow the trees to be taken up at the North; and if sent at that season, they frequently vegetate on the passage, and cause grent loss to the purchaser. In the fall, no difficulty of this kind will occur, and trees are annually sent to the far western States at that season, with entire success. The utmost care is taken to label distinctly, according to the invoice sent, every variety of tree or plant ordered. .They are packed in ma!ted bundles or boxes, according to the distance and probable exposure.

Ornamental Trees and Shrubs. - These can be had of every variety They are fully enumerated only in the catalogues of Nurserymen, and various books upon these subjects.

\section{DOIMISSTIC A.TMIATAXS.}

Our agdvice to the purchasers of domestic animals is, alunys to clioose groot ones, even at at much higher price than ordinary : for with select males, one can rapidly breel good ordinary stock from rather indifferent females of the country. The cost of transportation, and the keep afterwards, is no more for a good than a poor animal; and there is the adlitional satisfaction about their possession, that one has something for his money worth breeding from.

Season for Purchasing ani Shipping South. - The best season for pur. chasing is in the fall of the year, as stock is then cheaper and can be more safely transported. Orilers, if possible, should be forwarled at least tu'o months before it is wished to have them executel, so as to give sufficient time and opportunity to look abnut and make selections. For want of this we are often obliged to execute orders at great disadvantage to the purchasers. It must be recollected, also, that Northern rivers frecze up corly in December, making it cinite impossible to procure choicestock after this period, as most of the good breeders reside at a distance from the city in the interior of the country. Many an order for stock which has come to us in the winter we could not execute till the following autumn We hope our Southern friends will bear this praticularly in mind, as it will save them disappointment, and us considerable troni]\}.

September, Oetoher, and Nowember, are the jirnper seasons for shipping stock South, as the animals acclimate much better than when sent out in the spring. It is very hazarilous, nd almost certain death, to take cows or bulls South a" 
any other season, for the following reason. The average pulse of the ox is about forty in a minute at the North, while at the South it increases to seventy or more, and rises upon excitement to eighty-just double what it is here. This is a very important change in the arterial system, and if the animal be loaded with flesh, it is much more liable to disease and death.

Honses. - Thorough-breds may be bought at various prices, from $\$ 200$ to $\$ 5,000$, according to their age and reputation on the course, and as breeders.

Norman Horse.

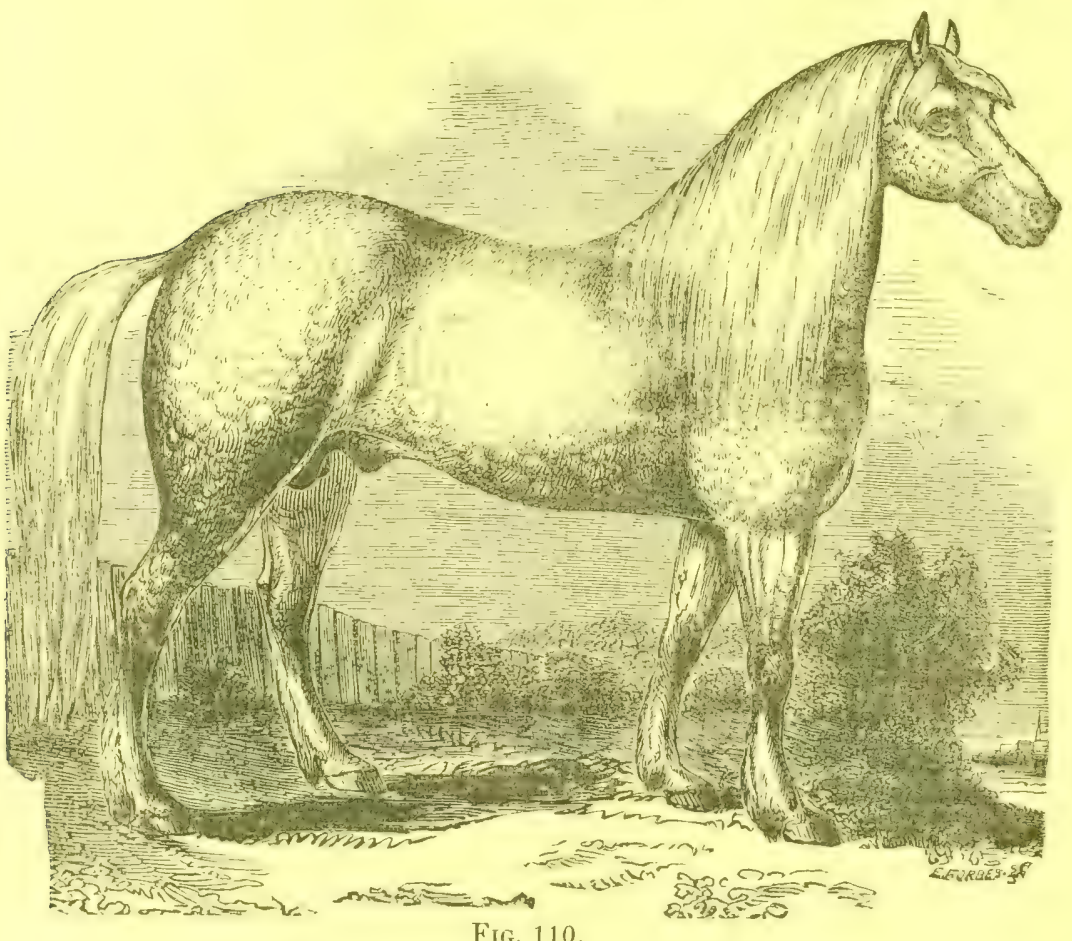

Roadsters, from 15 to $16 \frac{1}{2}$ hands high, vary in price according to their style, action, and speed. Single horses, which can go a mile in four minutes or ten miles in an hour, will command from $\$ 200$ to $\$ 500$; such as can do a mile in about three minutes, and fourteen miles in an hour, are held at $\$ 300$ to $\$ 700$; while those still faster, are worth from $\$ 500$ to $\$ 1,500$, according to circumstances. Some of the fastest sporting horses sell as high as $\$ 3,000$ to $\$ 5,000$ each. Match horses are held, under the same circumstances and prices, as single horses. Good, handsome pairs, six years old or so, may be had from $\$ 500$ to $\$ 600$; superior, from $\$ 700$ to $\$ 1,500$, according to fancy. Stall on leck must invariably be built at shipper's expense, costing from $\$ 8$ to $\$ 15$. 
Freight, $\$ 20$ to $\$ 30$; feed $\$ 7$ to $\$ 12$. When a number are taken, the expense is proportionably lessened. A groom should alway's accompany horses, as no dependence can be placed upon any one on board ship, to take care of them

DurhaM BULL.

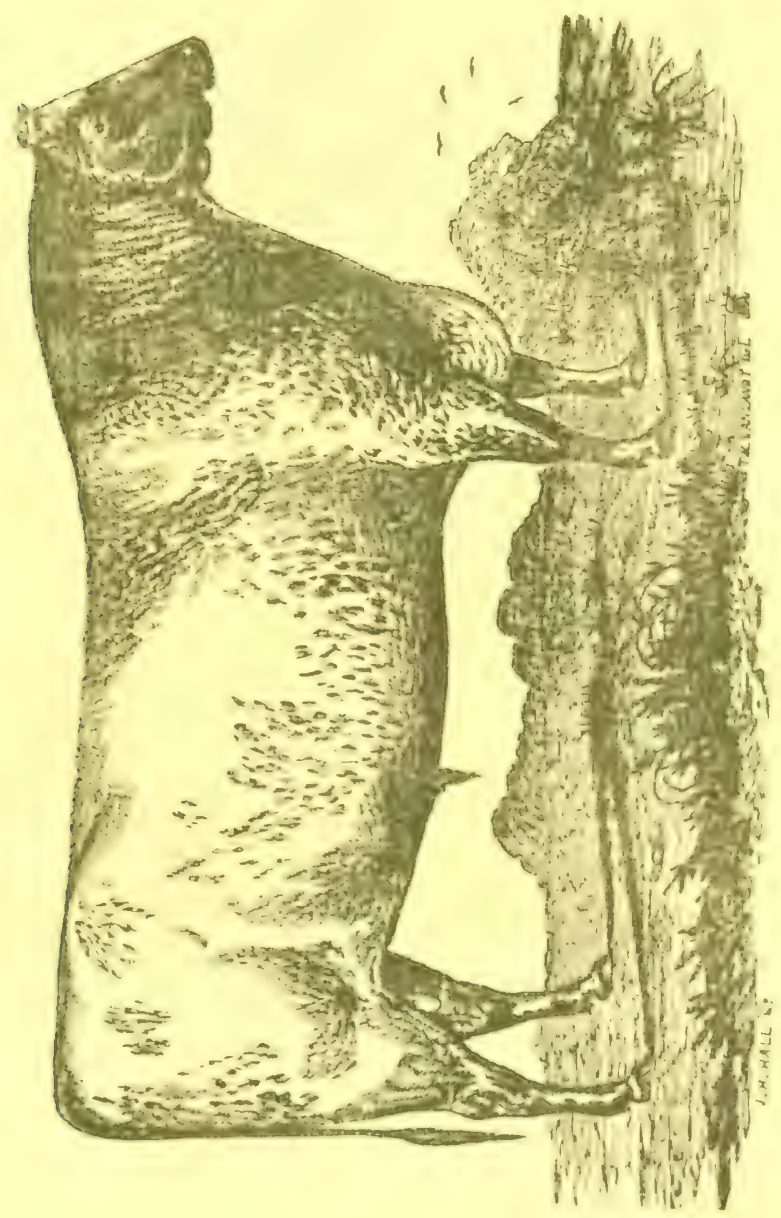

Fro. 111.

CartL..-For great milking qualities and good beef, we recommend tlie Dur. lam, and would prefer sending them South, from six months to one year old never over eighteen months old. The price for good Herd Book animals ranges from $\$ 100$ to $\$ 200$; very choice, about $\$ 300$ each. 
The Herfords are superior in the yoke to the Durhams, make excellent beef. ard are fair milkers. Prices same as Durhams

\section{Durham Heifer.}

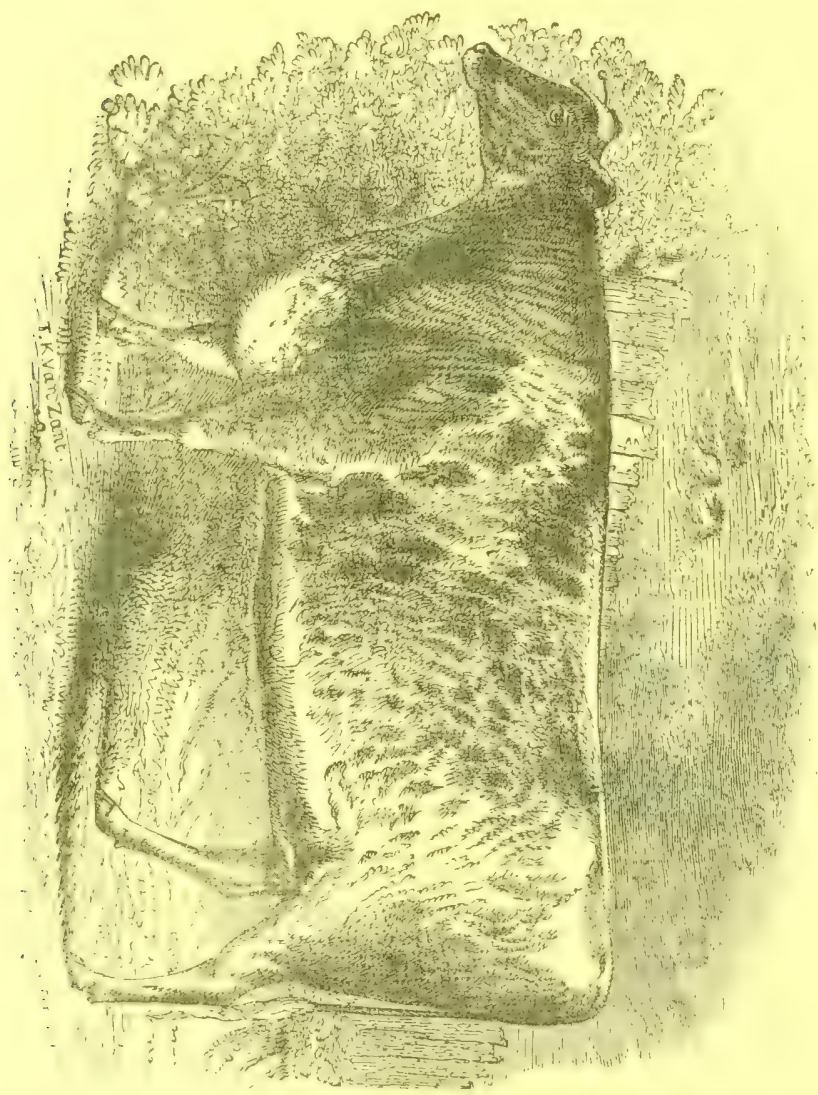

FIG. 112.

Devons. - The same may be said of the Devons as of the Herefords, except they are not so large in size by one fourth. Being a smaller breed than the two others, they are well adapted for the light pastures of the South. Prices 25 per cent. less than Durhams or Herefords.

Good milking cows for family use, are worth from $\$ 40$ to $\$ 50$; very superior and well bred, $\$ 60$ to $\$ 75$ each.

Freight of cattle South, from $\$ 10$ to $\$ 15$ each; feed, $\$ 6$ to $\$ 10$. Stalls are generally necessary for their accommodation, and cost from $\$ 8$ to $\$ 12$ each, according to the size of the animal. 


\section{Sixox Buck.}

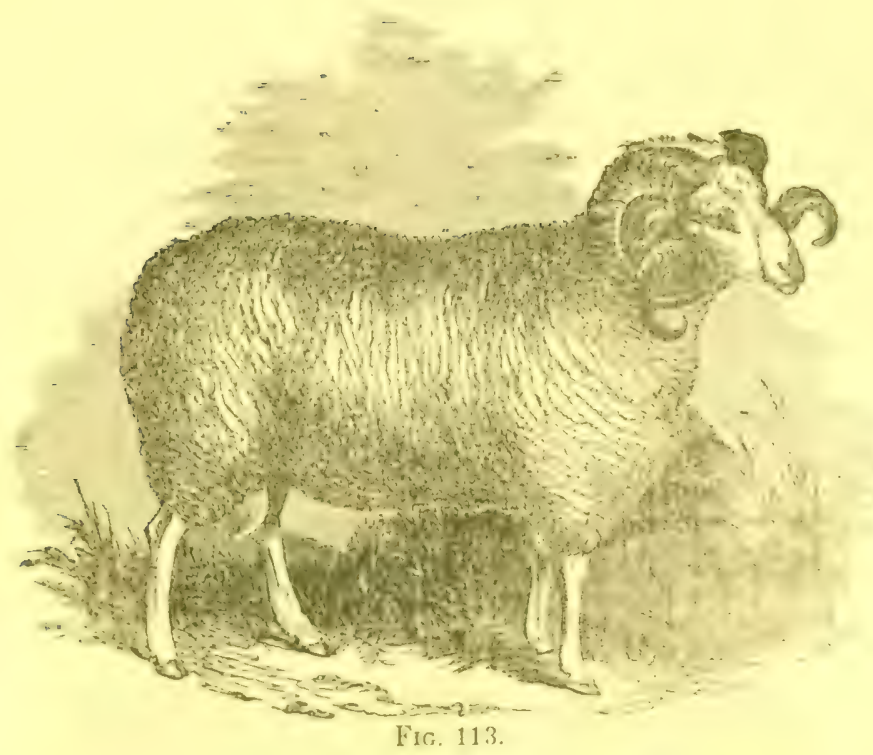

Merino Beck.

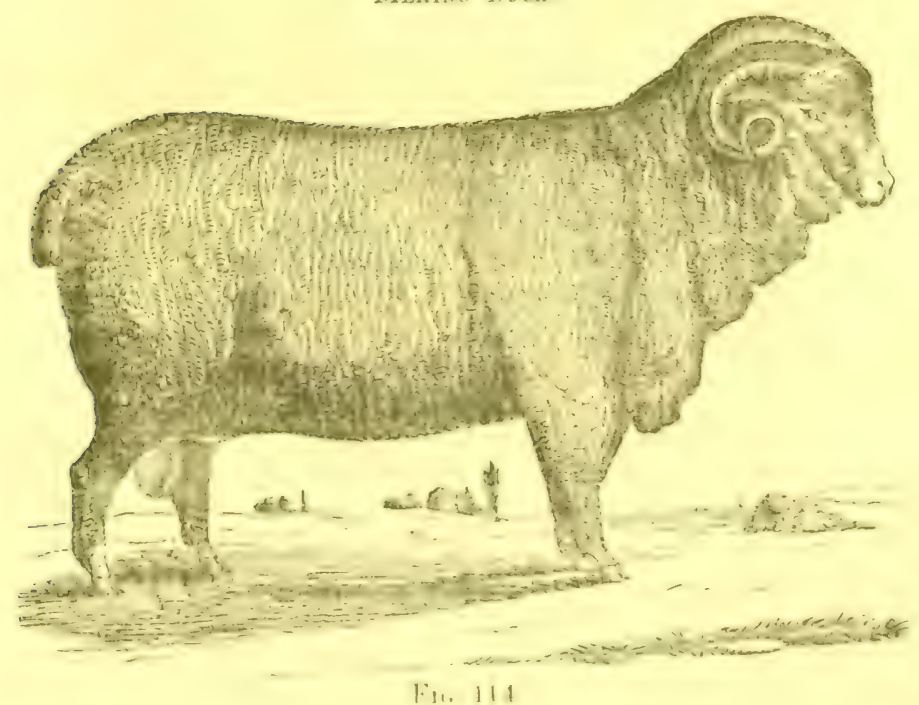

SHFEp - Fine IInollad. - The Saxons bave the finest fleeces, but are smaller than the Merinos. Ewes yield from two to three lbs. per Lead, of clean 
vasked wool; bucks from four to six lbs. Bucks are worth from $\$ 15$ to $\$ 30$. aves from $\$ 5$ to $\$ 15$. When a number are purchased they come cheaper.

Merinos. - In this class, the Rambouillets stand the highest. They are he largest in size of any fine woolled sheep; shear the heaviest fleeces, weigh'ng from four to fourteen lhs. clean washed, according to the sex, \&c., and of a juality, only one grade inferior to the Saxony. No ewes of this breed will be for sale probably betore the year 1850. Bucks can be had for $\$ 50$ to $\$ 200$ each, according to age, quality, \&c.

Native Merinos may be had from $\$ 5$ to $\$ 50$ each. They are valuable sheep, shear about one fifth less than the Rambouillets, and of a quality of wool one grade inferi,r.

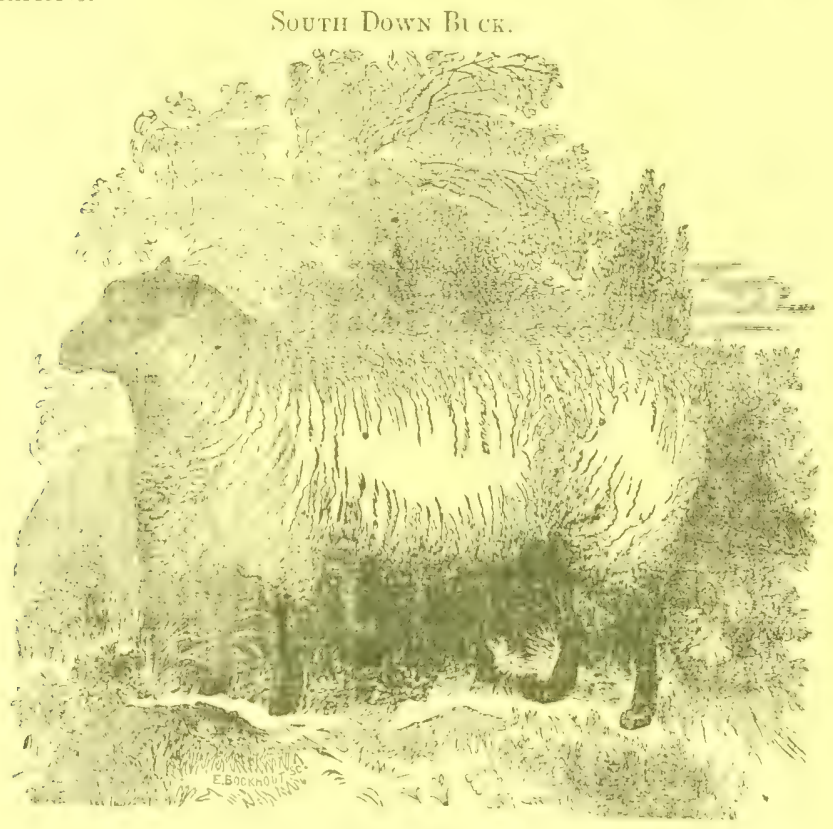

FIG. 115.

Souru Down.-This is a very hardy breed of sheep, yielding the best of nutton, lean, tender, and juicy. Their hams, when properly cured, can ; carcely be distinguished from the finesi venison. They shear from three to eight lbs per head, of clean wool, according to the sex, \&c., of a medium quality, very open and easily worked, and especially suitable for plantation use Mutton is much more healthful than pork, especially in a hot climate, and when accustomed to it, more palatable. Price $\$ 15$ to $\$ 30$ each.

Cost of Shipping Sheep South.-Freight from $\$ 2$ to $\$ 5$ each, according to the number, size, \&c.; feed, $\$ 1$ to $\$ 3$. Stalls $\$ 1$ to $\$ 3$. If thirty to fifty sheep are taken, they can be shipped at a moderate expense per head. 
LONG IV OOLY,HD BUMr.

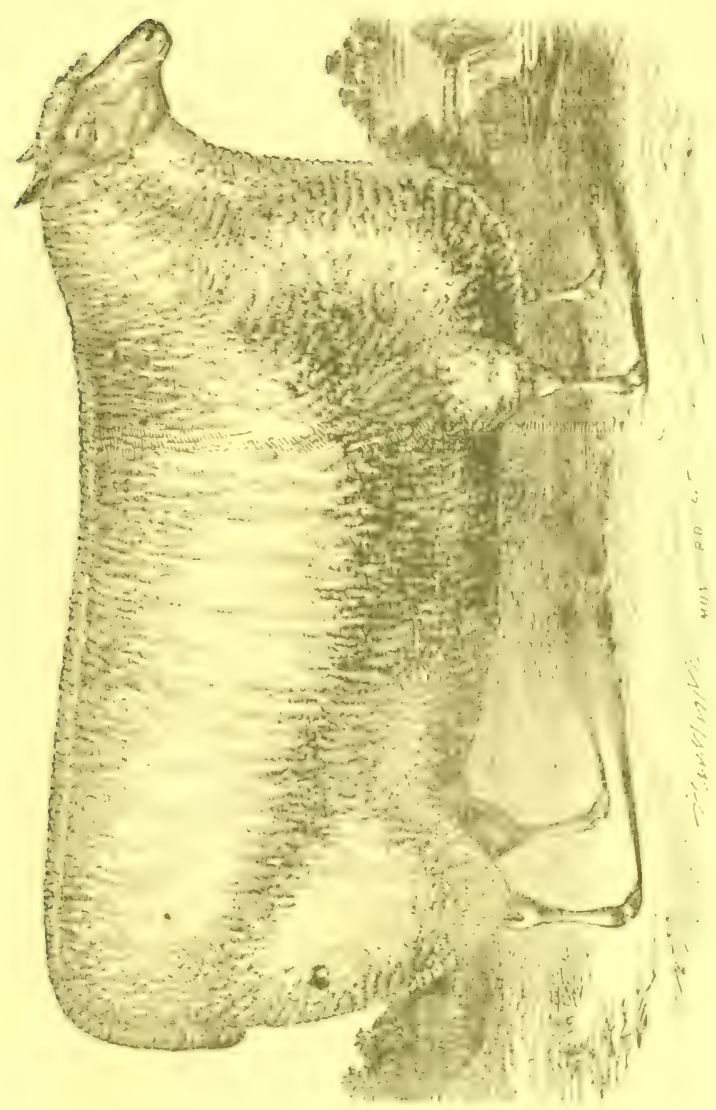

Fig. 116.

Losg Wool SHeEp.-These are all essentially the same, thourh they fing under the different denominations of Bakewell, Leicestershire, Lincolnsinte Cotswold, Oxfordshire, Sc. These are the largest class of sheep in this curn. :ry. 'Their mutton is rather too fat for good eating. They shear from five ic lwelve lbs. of clean washed wool, according to the sex, \&c., suitable for worst. el combing. Price from $\$ 15$ to $\$ 50$ each. They make an excellent cross on the common sheepl of the country, both for wool and mutton for plantation use. 


\section{Berkshre Hog.}

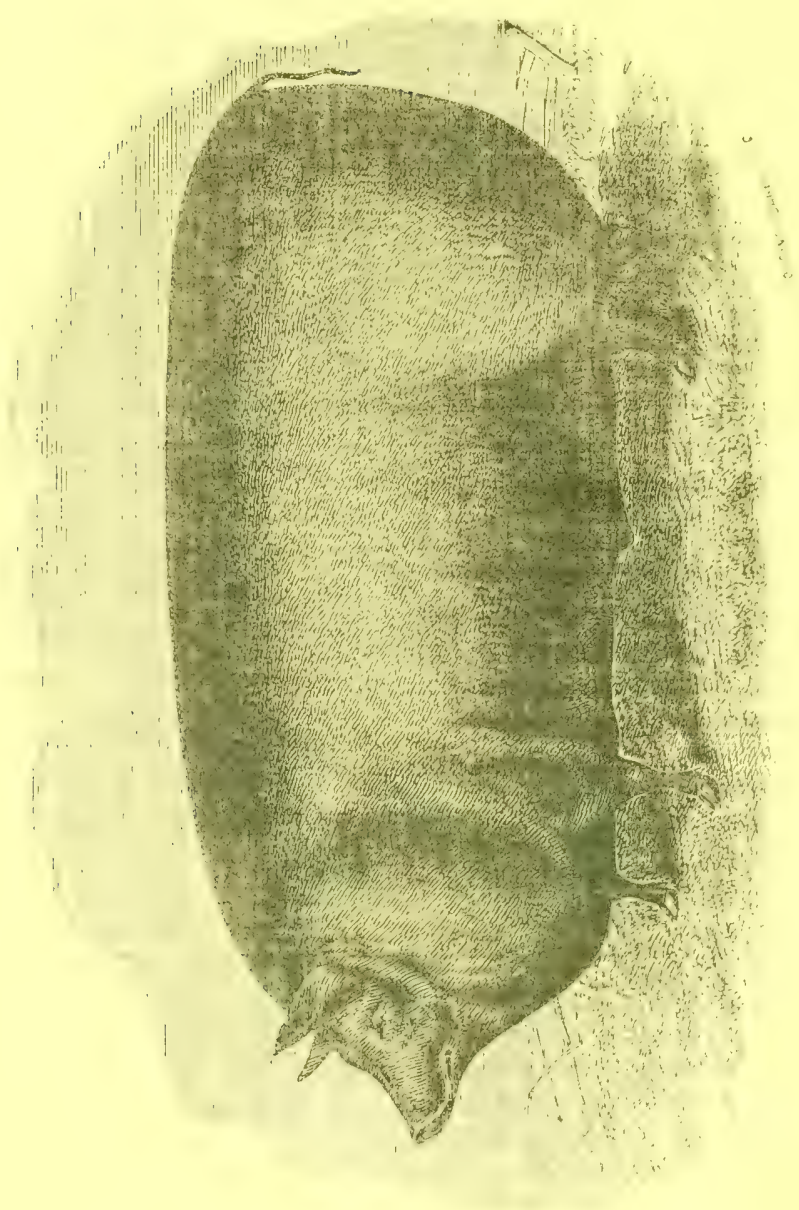

FIG. 117.

SwINE.-The Berkshire breed has hitherto been most highly esteemed, though some pretend to say they do not stand the Southern climate so well as the Neapolitan, or white English breed. These, as well as the Woburn, Bedford. Mackay, Byfield, Grass, Leicestershire, and indeed all good improved varieties, are merely crosses of the Chinese-that is, they are grade China hogs. Wo wish our readers to bear this especially in mind. In giving orders, it is only necessary to say what color and size is required, without signifying the name of the breed, at we profess to be good judges of all kinds of stoch, and 
can thus make better selections than if hampered with special instructions The China breed are too small and fat to go to the South. They are also delicate and shy breeders. Their crosses are superior to themselves for the farmer. Pigs should be three to four months old, at least, before being shipped.

Prices, caged, $\$ 20$ to $\$ 30$ per pair. Older ones come much bigher, say $\$ 20$ to $\$ 30$ each. Freight $\$ 3$ to $\$ 6$ per pair. Feed $\$ 2$ to $\$ 4$, according to the length of the voyage.

Observation.-Something must always be allowed for the expense of detention of animals in the city, from the time of their arrival to the sailing of the ship. We conclude by saying, that before any one orders stock they should take into consideration the following three things: First, be completely prepared to keep and breed them. Second, select none but the best, and these with a reference to improve what you already have. Third, have some faithfui person, if convenient, to accompany and take care of them. 'This last, however, is not essential; for out of the hundreds of animals we have shipped West and South, most of them have arrived safely at their place of destination, from the care observed in shipping and providing for them on the voyage 


\title{
A P PENDIX.
}

\author{
STMAII-LWE. INE.
}

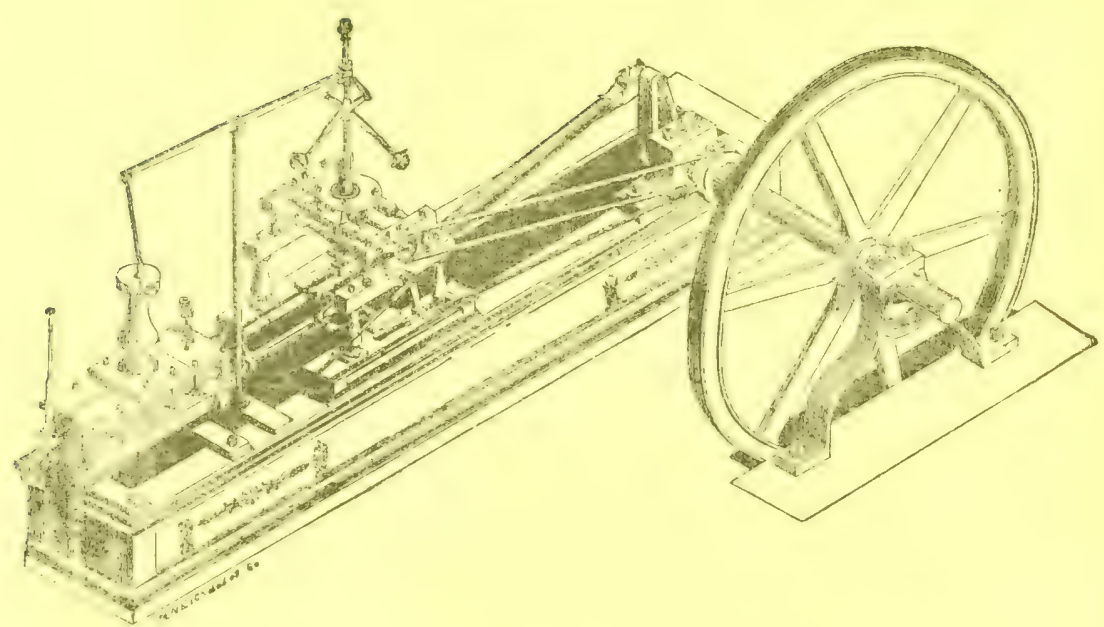

FIG, 118.

Within a few years, the steam engine has been apphed in Grent Britain to the purposes of agriculture with economy and marlied success. It has been found very useful in threshing, winnowing, and grinding grain, crushing linseed, cutting chaff and other forder for stock, and will do sundry other things on the farm and plantation, such as grinding apples for cider, pressing cotton and hay, grinding sugar cane, sawing wood, pumping water, churning butter, \&c., \&c.

There are engines made in New York, in a portable form, with boilers attached, which can be transported from one farm to another, at a moderate expense, and they can be easily employed by night as well as by day. All things considered, an engine of this kind cannot be lookee upon otherwise than of great pecuniary advantage on a farm, as the expense for fuel and attendance of running one of six-horse power, will not exceed 25 or 30 cents per hour 
Cast-Iron Garney-CHams.

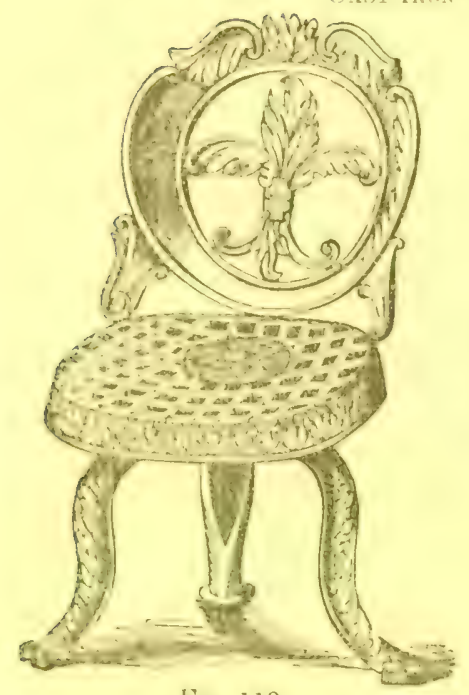

'These are mide of various patterns, covered with durable patist which will resist the influence o: act weather. Price $\$ 1$ to $\$ 10$ each.

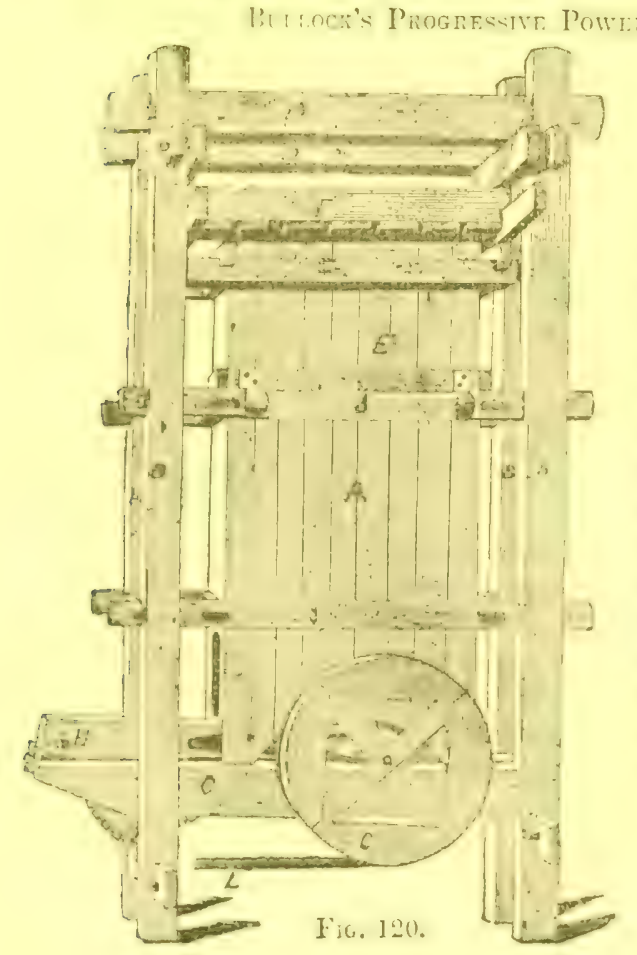

'These presses all' in use for compressing cotton, at our seaport towns, and for packing cotton in all the cotton-growing states : for baling dry croods in factories and watrehouses; for pressing woollen cloth in the process of mamufic'turing, and for pressing oil, lard, \&ce., inclubing every variefy of size and form that mey be required, for all the varous precesses for which they atre used. Prices from \$100 to $\$ 1,000$ cuch. 
Thermometer-Churn.

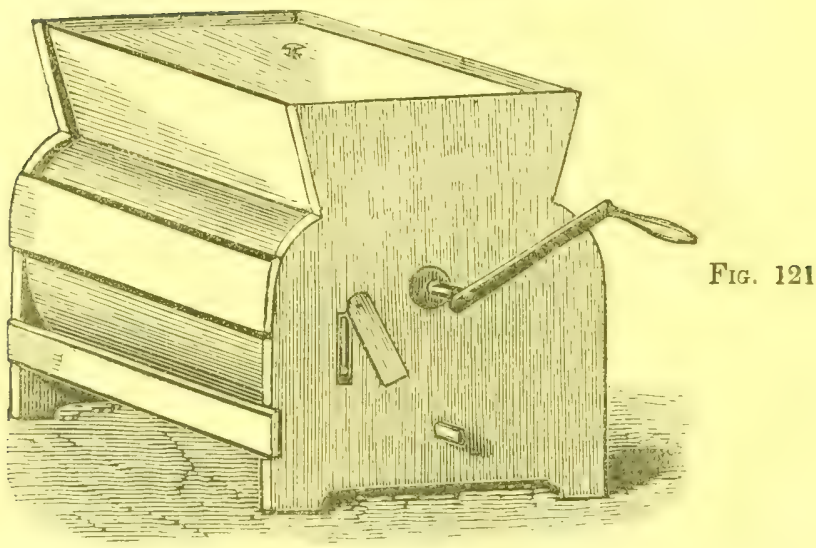

This churn is so constructed that the cream or milk is readily brought to the desired temperature without mixing water or other substances, and the temperature certainly and definitely determined, which proves invaluable in the art of making butter.

One improvement consists in the construction of a double bottom made in the form of a semicircle, of two sheets of zinc, or other metal, placed one above the other, the cream to rest upon the uppermost. Between the two sheets forming the bottom, is a space, or chamber, into which may be introduced cold or warm water, as may be required to increase or diminish the temperature of the cream or milk. The water is easily applied by means of a common tin tunnel, through an aperture: or hole, in the side of the churn.

Another improvement is a thermometer permanently placed in one end of the churn, entirely secure from breaking or accident, marked at $62^{\circ}$, and which is always visible, so that the operator may know and determine with certainty when the cream or milk is brought to the proper tempurature. If the cream or milk is too warm, the mercury in the thermometer will rise above the mark of $62^{\circ}$, and cold water should be applied in the chamber described; if too cold, the mercury will fall below the mark, when warm water must be used instead of cold. The cream or milk should be stirred or agitated, by turning the crank, while the water is being introduced, to give the cream or milk an equal temperature throughout. When the thermometer indicates that the cream or milk is of the proper temperature, the water may be drawn out through the tube placed for the purpose, when the churning should be performed by giving the crank about forty revolutions to the minute By reversing the motion of the crank, it is liberated, when both it and the dasher, or floats, are drawn out. 
WEYL.WHEEL.

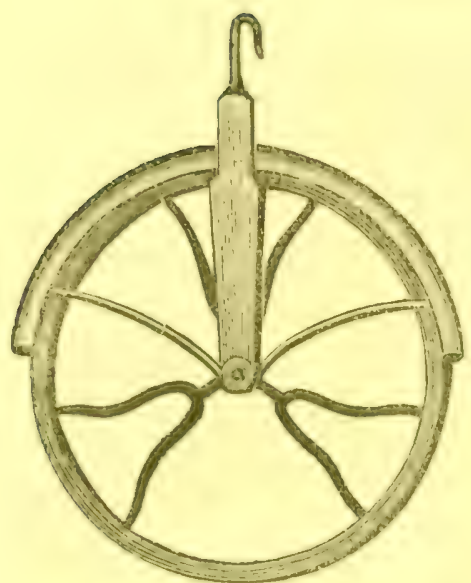

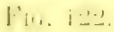

This is a cheap tixume with a rope to raise water from wells, and is admirably adapted for raising and lowering light weights about stores and warehouses, ns it works with much ease and expedition.

\section{Coes' Anjtstable Screw-IVifinches.}

In the arrangement, combination, and proportions of the parts, these wrenches are acknowledged to be the most convenient, cllicient, and strongest now made, and having been long in use and fully proved, are most favorably linown among our mechanics.

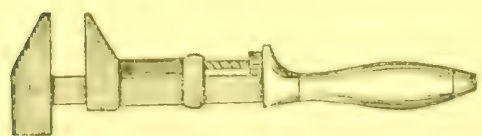

Fis. $122 !$

The screw which mores the sliding jaw is most expeditiously and easily operated by the thumb of the hand that grasps the handle, and the space between the jaws is adjusted to the size of the nut or screw, to be turned under any circumstances more easily without than with assistance of the other hand, which maty be otherwise engaged.

By placing the screw that moves the traversing jaw by the side of she shank or main bar of the wrench, the full size and strength is retained.

Pruning SAT.

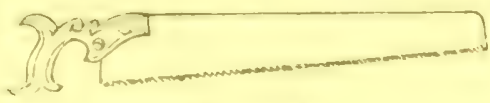

FIG. $122 \%$

This form is most commonly used, and is of varions sizes, with fine tecth. It is usually from fourteen to eighteen inches long. 
Truck Wagons for Stone, Heavy Timber, etc.

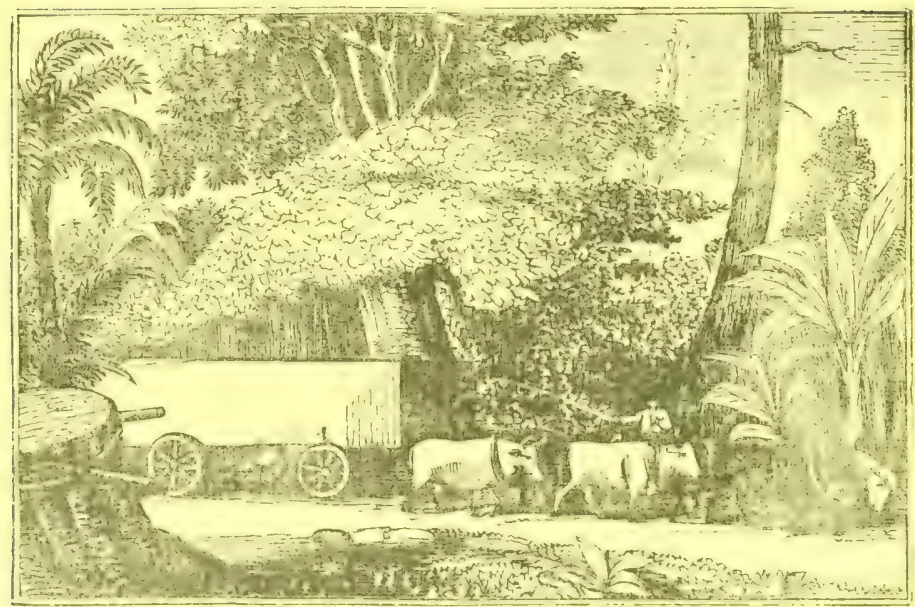

Fig. 123.

These are constructed of various sizes, with four, strong, iron-bound wheels to each, and are adapted for the transportation of heavy timber, stone, large castings, sc. \&c. Prices, complete, from $\$ 75$ to $\$ 125$ each.

\section{Two-Horse WAGONS.}

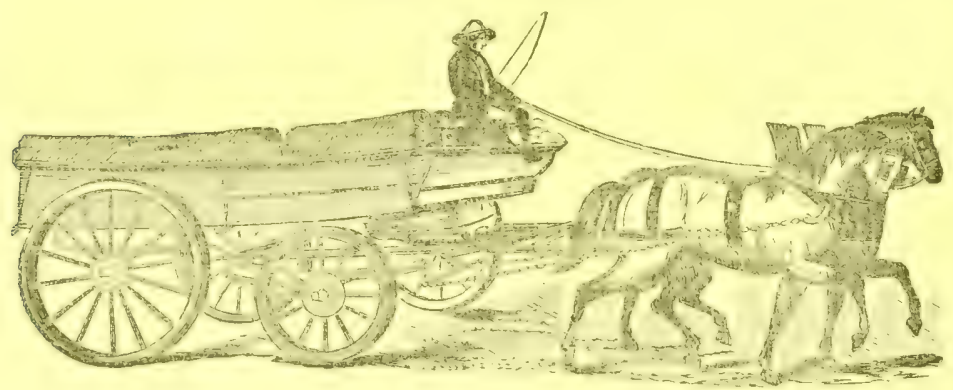

FJG. 124.

These are constructed with light, breal bolies, and will carry, on a gond road, from two tons to two tons and a half of grain, or salt in bags, and wili load well with hay or straw. The bodies are mounted on patent iron axles, and elliptical steel springs. They are designed for market or farm use, and require to be drawn by two or more horses. They may also be driven with ease, when loaded, at a speed of four or five miles per hour. Prices, for a good article, $\$ 85$ to $\$ 140$, complete. 


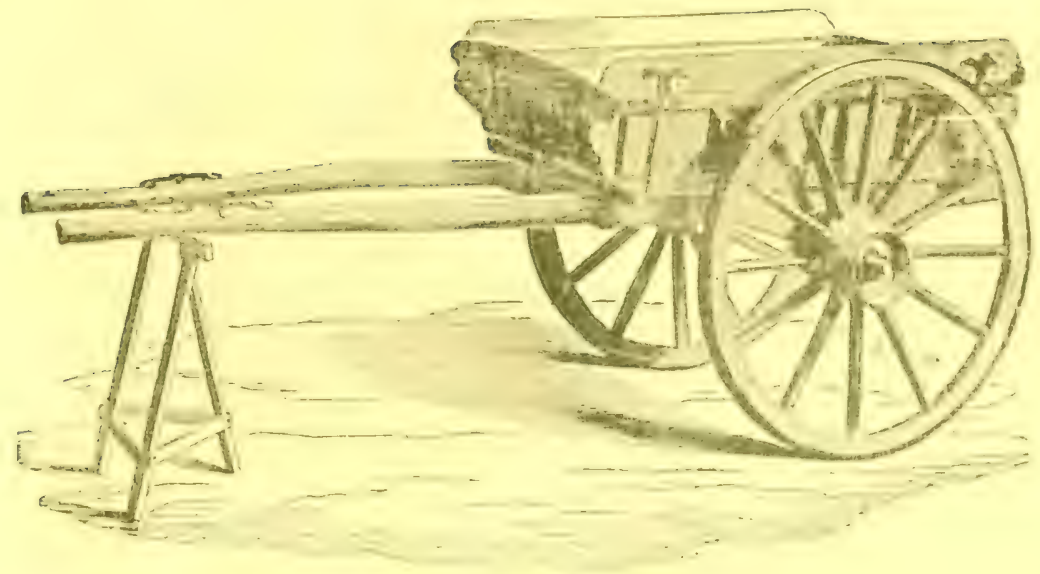

FI. 125.

The cut above represents a very useful farm and plantation tumbrel cart. It is more convenient than a four-wheeled wagon in many respects

It car be worked either by one or more horses. One or two additional horses can be hitched to it side by side, to draw outside the thills, or they can draw in tandem, if preferred. It admits of easy backing or short turning, which is of great advantage in particular locations, and especially among thickly-planted rows upon the field.

But its greatest advantage is in the facility of dumping or upsetting the loar, by removing the catch, or staple, which confines the box upon the thills in front, when a little effort sends the box nearly perpendicular, whirling over upon its axis (the axletree), by which the load is summarily disposed of. In discharging dirt, manure, sugar-cane, and many other crops, this is an item of great consideration. Prices, from $\$ 50$ to $\$ 80$, complete.

\section{Canat and Ralload Barrows}

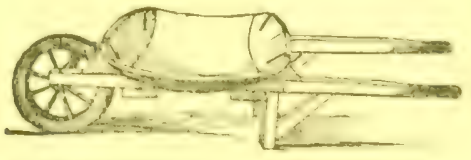

Fif. 126 .

These can be furnished of various sizes and mocies of construction, from $\$ 2.25$ to $\$ 5$ each. 
Ratlroad Cars, Coaches, Ommibuses, etc.

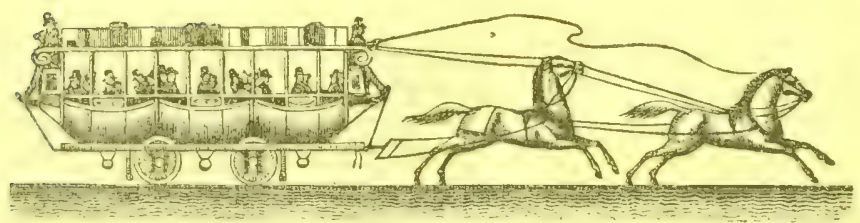

FIG. 127.

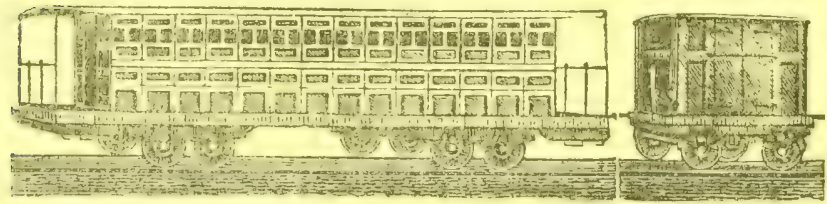

FIG. 128

FIG. 129.
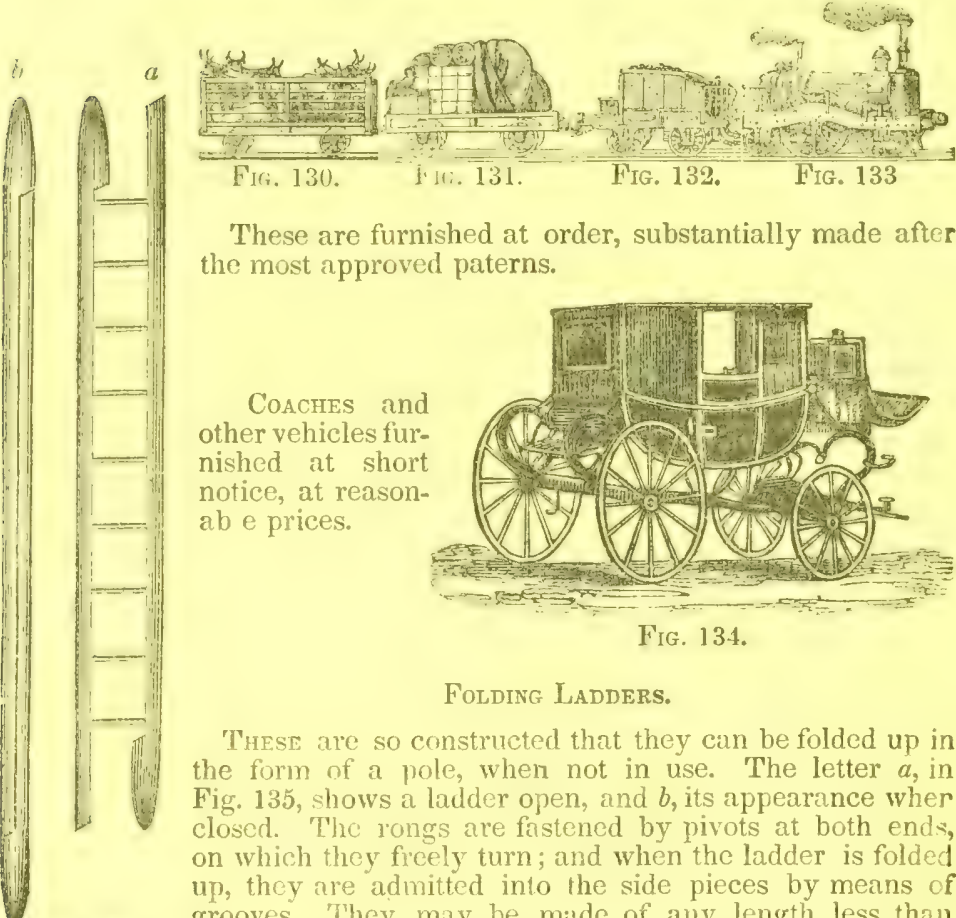

FIGi 130 .

fi. If. 131 .

FIG. 132 .

FIG. 133

These are furnished at order, substantially made after the most approved paterns.

COAches and other vehicles furnished at short notice, at reasonab e prices.

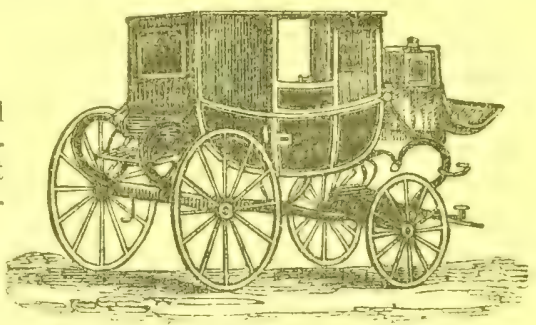

FIG. 134.

Folding LadDers.

THFse are so constructed that they can be folded up in the form of a pole, when not in use. The letter $a$, in Fig. 135, shows a ladder open, and $b$, its appearance wher closed. The rongs are fastened by pivots at both ends, on which they freely turn; and when the ladder is folded up, thcy are admitted into the side pieces by means of grooves. They may be made of any length less than FIG. 135 15 feet, at 30 cents per foot; but when longer than this, the rate per foot must necessarily be increased. 


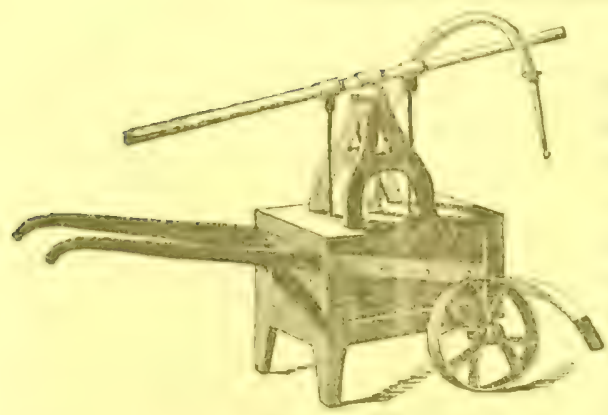

Fig. 136 .

'l'hese are made of two kinds, the single or forcing, and the double or suction and force. The first requires to have the water delivered in the box, and the other will draw water from any depth not exceeding 30 feet, and force it equally as well as the first. They are easily worked by two persons, and will throw the water some sixty feet in height. Beiner placed on wheels, they can be removed wherever desired. Engine's somewhat resembling that denoted by fig. 136, have been in use for some: years, but the present ones combine some advantages and improvements nver any heretofore einployed.

GifDen Roller.

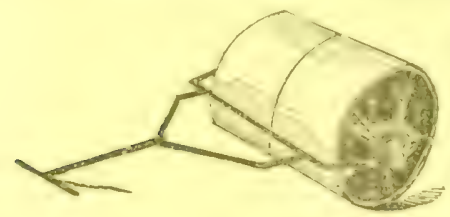

FIG. 137.

'This implement has been latety very largely introduced for hotticultural and other uses. It consists of two cast-iron sections, one foot in width, and twenty inches in diameter, with an iron handle. The most com. plete ones have two large weights suspended from a shaft within the sections, to grve them additionial weight, and these are so adjusted as to throw the handle up when not under the control of the hand, thus always keeping it clean. 'Though senerally used by hand, only, a horse can be readily attached to the handle for any heavy work. 'They are made in two sections; to obviate: the very bad effect in turuing, where the entire roller is solid, by when the earth is scraped up on either side at the siune time that it requires much additional power to move it. As now arranged, when turning, one: roller is moving back while the other is moving forward. 'There is a further advantage from having small sections, in the consideration that if one, by any mishap, becomes broken, its place can be supplied by another, without prejulice or loss to any other part of the machine.

T'He Fiefo Roliser is made from sections of the same width, but of larger diameter, and each of domble the weight of those in the hand roller. They have the further addition of a large wooden box, to hold any increased weight required, as they are always moved by a team, and are used for roads and ficlds, where large weights are necessary. But as the latter has been particularly described at page 21 of this catalogue, we: omit furthernotice of it here. 


\section{WiRe Fences.}

These possess scveral prominent advantages-economy of room, economy in expense, cconomy in repair, durability, and tastefulness. Wherever timber is not absolutely without value, a wire fence is

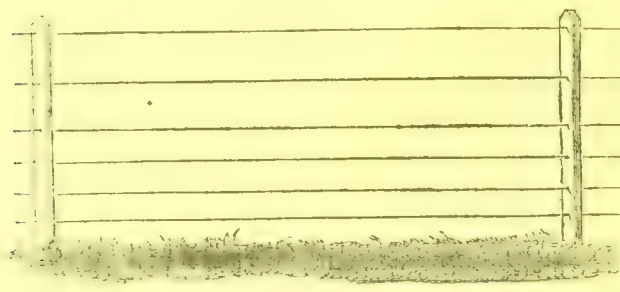

FIG. 138. cheaper than the commonest zig-zag or Virginia-worm fence. It costs less than laying a stone wall, even if the stones were hauled gratuitously. The expense of keeping in repair is less than that of any hedges, fence, or wall, unless the latter is of the most massive kind; and

it ocupies no room.

To answer the numerous inquiries for the cost, weight, and sizes of wire, annealed and properly prepared for fences, we append the following table.

\begin{tabular}{|c|c|c|c|c|c|c|c|}
\hline $\begin{array}{c}\text { Class of } \\
\text { wire. }\end{array}$ & $\begin{array}{l}\text { Diameter in } \\
\text { hundredths } \\
\text { of an inch. }\end{array}$ & $\begin{array}{l}\text { Weig } \\
\text { lineal }\end{array}$ & $\begin{array}{l}\text { ht per } \\
\text { rod. }\end{array}$ & $\begin{array}{l}\text { Weigh } \\
\text { lineal }\end{array}$ & $\begin{array}{l}\text { ht per. } \\
\text { mile. }\end{array}$ & $\begin{array}{l}\text { Retaj } \\
\text { prices } \\
\text { poun }\end{array}$ & $\begin{array}{l}\text { il } \\
\text { s per } \\
\text { ad. }\end{array}$ \\
\hline No. 1 & 0.32 & 4 lis. & $2 \mathrm{oz}$ & 1321 & lbs. & $\$ 0.09$ & cts. \\
\hline 2 & 0.3 & 36 & $10 \cdots$ & 1166 & & 0.09 & \\
\hline 3 & 0.27 & $2 \quad 6$ & $15 "$ & 944 & 6 & 0.09 & .6 \\
\hline 4 & 0.25 & 26 & y. & 809 & $"$ & 0.09 & " \\
\hline 5 & 0. 24 & $2 \quad 4$ & 5. & 746 & $"$ & 0.09 & 6 \\
\hline 6 & 1).22 & $\because$ & 15. & 627 & 66 & 0.09 & 6 \\
\hline 7 & 0.20 & 16 & $9 \cdot 6$ & 518 & " & 0.10 & .6 \\
\hline s & 0.18 & 6 & $4 \cdots$ & 419 & 6 & 0.10 & $"$ \\
\hline 9 & 0.16 & :i & 0.4 & 331 & 4 & 0.10 & 4 \\
\hline 10 & (1) 1.5 & *. & $14 \cdots$ & 291 & 4 & 0.11 & 6. \\
\hline 11 & ก. 1.3 & $\because$ & 106 & 219 & $"$ & 0.11 & $\therefore 6$ \\
\hline 12 & (1. $1: 2$ & .6 & 0.6 & 186 & " & $0.111 / 2$ & $1 / 2^{64}$ \\
\hline 13 & 01.11 & $10 \quad$ " & $6 \cdot 1$ & 129 & $* 1$ & $0.121 / 8$ & \\
\hline
\end{tabular}

From 25 to 40 per cent. will be discounted from the foregoing prices, eccorting to the gantity, when purchased by the coil.

\section{Blachsmith's Portable Forge and Bellows.}

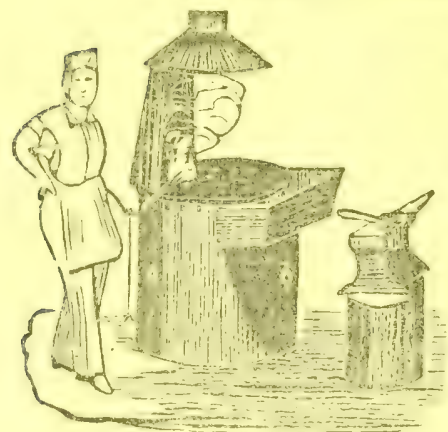

FIG. 139.

These are compact, light, and easily moved wherever required. They contain a bellows under the forge, and may be set in doors or out, as most convenient. The different sizes weigh from less than 100 to over $400 \mathrm{lbs}$, suited to all kinds of work, from a dentist's or jeweller's, to heavy smith's work. Price $\$ 30$ to $\$ 50$.

BLACKSMITH's TooLs of all kinds-invils, vices, tongs, hammers, sledges, stocks, taps and dies, drilling machines, punches, swedges, heading tools chisels, \&c. 


\section{Garden Srrmars}

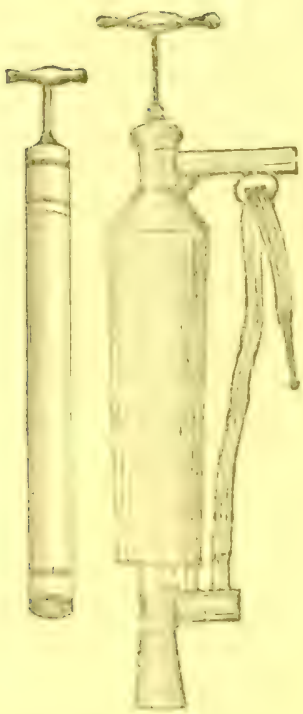

These are very simple and econonical implements, constructed on the principle of a foree pump; and arr. we kll ealculated for wiatering erirdens or washing windows. They may also be used for expelling insects from shrublery and plants, by means of an infusion of tobuceo or sulphur water. lhey are various sizes, throwing from a pint to a gallon at eich stroke.

FIG. 140, I'IG. 1.11.

'IthINTON's IMPROVEn P'ATENT SMUT MACHNE.

This machine has proved itself to be one of mmivilled excellence. It

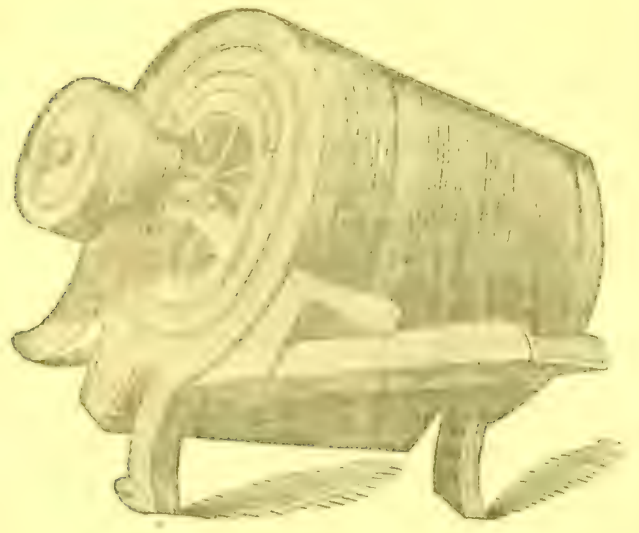

FIg, 142. is warranted to answer every purpose of the most complete and expensive machinery of screens, rubbing stones, tius, \&ce., and will thoroushly clean the must smutty whoat. It is the best contrivance to talke out chess. onions, and heavy grit, that hits been introduced to the notice of millers, and is the most complete screen rerr mate. "This machine is provided with self-acting oil feeders to the journils, and wholly does away the small fin. It rums at the rate of 1,000 revolutions per minute. 'This machine requires but little power, and there is little linger of fire, and it wants oiling or greasing only once a week. Price sio. 
BuAsting Toous.-These consist of twelve drills of various sizes and shapes; one each-rammer, needle, and cleaner, made in the most perfect manner with cast-steel points, or of solid steel, as may be desired. Also drilling hammers, with double and single faces, sledges, \&c.

California Tools, of all descriptions, including mining and blasting tools, gold-washers, retorts, crucibles, chemicals for testing ores, small balances, \&c. \&c.

Indestructible Mineral Paint-A most admirable and effective preservative from the injurious effects of the weather and preventive of fire, becoming in a short time after being ground or mixed in oil, of the consistence and quality of slate. For manutactories, railway depôts, roofs cf all descriptions, public buildings, fences, \&c., it is invaluable. For sale bv the barrel or ton, at $\$ 4$ per 100 lbs.

\section{Sugar-Mirls for Grinding Cane.}

These are furnished of all sizes, to work by horse or steam power. They are made with two and three rollers, and work horizontally and vertically for horse power; and with three horizontal rollers of larger

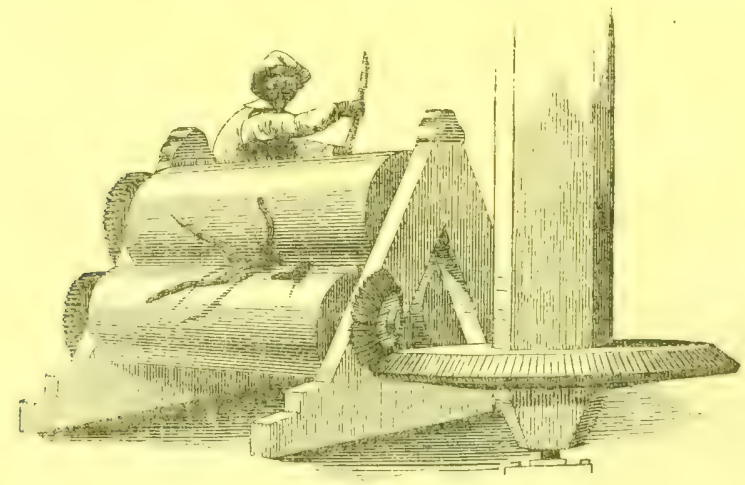

FIG. 143.

dimensıons for steain or water power. Great improvement has recently been made in the construction of these mills, both in economising power and the cane juice. Fifty per cent. is near the average of juice heretofore expressed from the cane, leaving about forty per cent. in the bagasse Machines are now constructed by which 75 to 80 per cent. of juice is extracted.

Price of horse-power mills with two vertical rollers and geering, brass boxes, and heavy-wrought shaft, $\$ 120$ to $\$ 200$. Horizontal mills, with three rollers for horse or steam power, $\$ 250$, to $\$ 2,500$. 


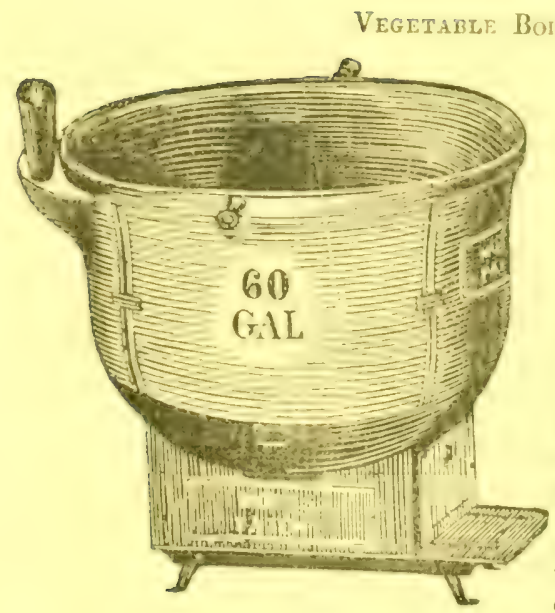

These boilurs cunsest of is ketfle placed over a cast-iron stove furnace, of which thry form a part. 'They can be placed out dooss of in a remen where the sumote is earried inte the ahimmet through at stow pipe. "There is spr:ati ecomomy of tiue hy this arrangement.is the dande batses on every side to the trop of t? hette. Manv of them are now used by sugar planters, with

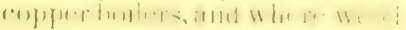
is scarce, they are of zrenet ad-

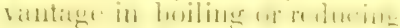
the sap, with the utmost econs. omy of fuel.

FIG. 144.

Pruning ant Bundixg Kvives.
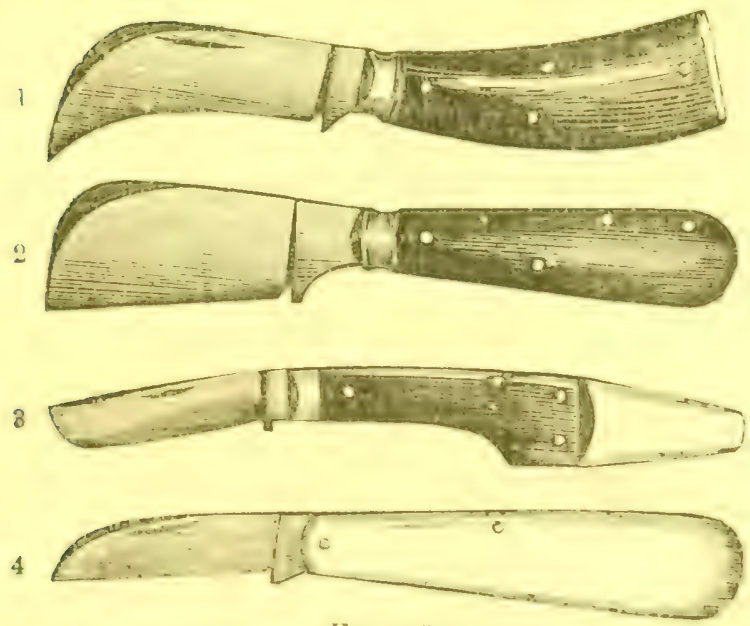

Fig. 1.15 .

Vos. 1, 2 and $f$ are suod and convenient form for pruning young trece and are made strong and heary for that purpose.

No. 3 represents the best and most approved form for buding. The edere of the blade is rounded at the point, and will shut up as a pocket knife. At the other end is permanemiy fixed a thin fhat ivory lifter. with which the bark is loosened and raised. after being cut to receive the bud. 


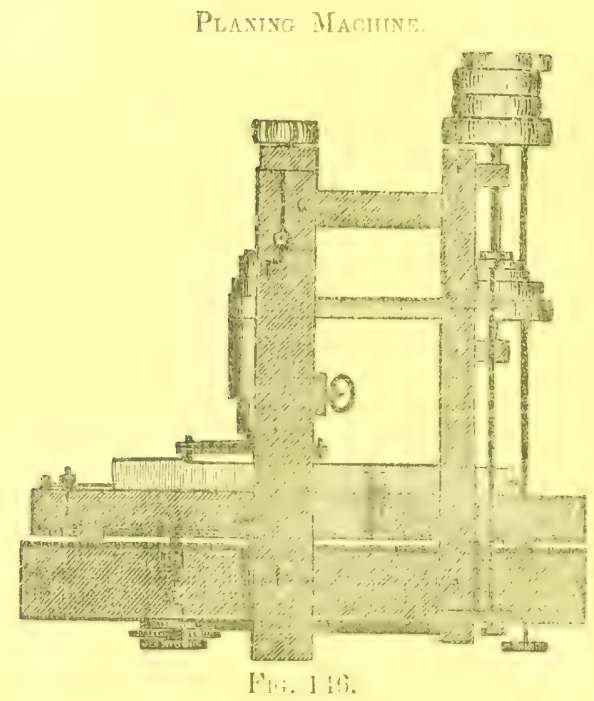

This machine is valuable for planing all lengths, widihs, and theck. nesses of joists, plank and boards, various kinds of mill work, and other parts of wood work for machinery, plows, \&c., \&c. It will plane hard or soft wnod equally well and with great rapidity. They have been used for many years with entire success through various pirth of the Union. There are several sizes to plane different widths, and l.01uths.

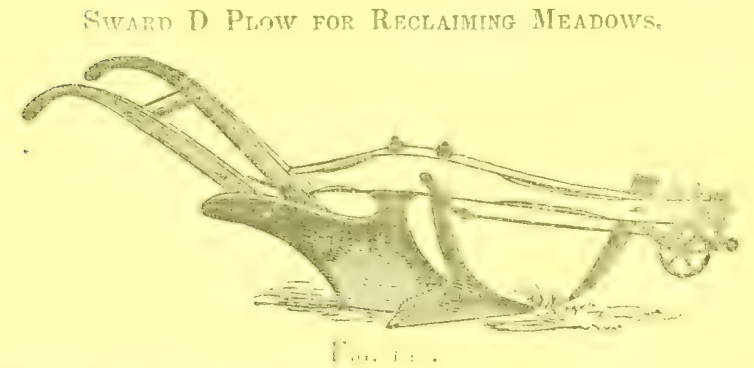

A strong four-horse plow, sime size and form as Sward B, with the addition of a wrought lock-couller, as attached to Eagle No. 2, Frg. 3 To this plow is affixed, when required, a sharp steel-edged share or point, cutting verv wide, and a reversed or drag cutter for the purpose 
of plowing and completely turning over the surface of wet mendows when drained by ditching. $\Lambda$ eranc-elevis is attached to the end of the beam which enables the off ox or horse to keep cleat of the miry npen furrow, so very fatiguing to him, and tread on the mberenen ground, thus making it comparatively easy work for the fram, and obriating the greit objection to breaking up wet meadows or swampy ground. The newly-invented dial-clevis and draft-rod, as described in Litgle No. 2, Fig. 3, will enable the off horse to tread on solid gromel in plowing wet meadows, nearly as well as the cranc-clevis. It also enables the plow man to run the plow elose along side of a fence or ditch. This would be an admirable plow for the stifl lands on the Mississippi, and for the frairie lands of the west. When the fixtmes for meadows are removed and the origrinal point or share repliced, the plow is agrin adiuted to the rugred upland soils, thus answering the double purpose of an upland and meadow plow.

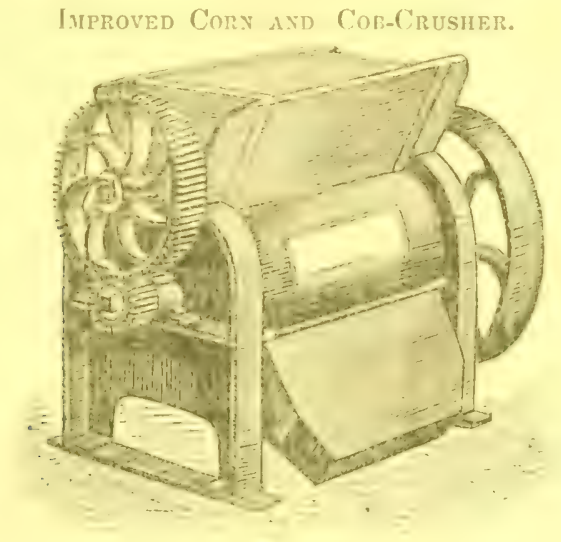

Fri. 1 l.

'This machine is designed for crushing corn and cols for fecding * stock, or previous to passing through mill stones for grinding into fine provender. It is also used to crack corm alome, sultahle for hommony or for the use of stathles. It has the morit of compactness, durability, miformity in its work, and cemony of power. Its height, when set up for work, is about 3 feet. It will grind the cols and corn to the same degree of tineness, and this if will do when the corn is damp, or eren groen, without clogging. It is generally driven by a four-inch beltit may be driven hy gear, however, wihout inconvenience-by which cobs and corn are cracked fister than one run of stones can grind them. It is also itsered by experince! millers, that any rum of stonewill grind at least one fourth faster and finer when the cobs are cut up in this manner. P'rice $\$ 50$. 


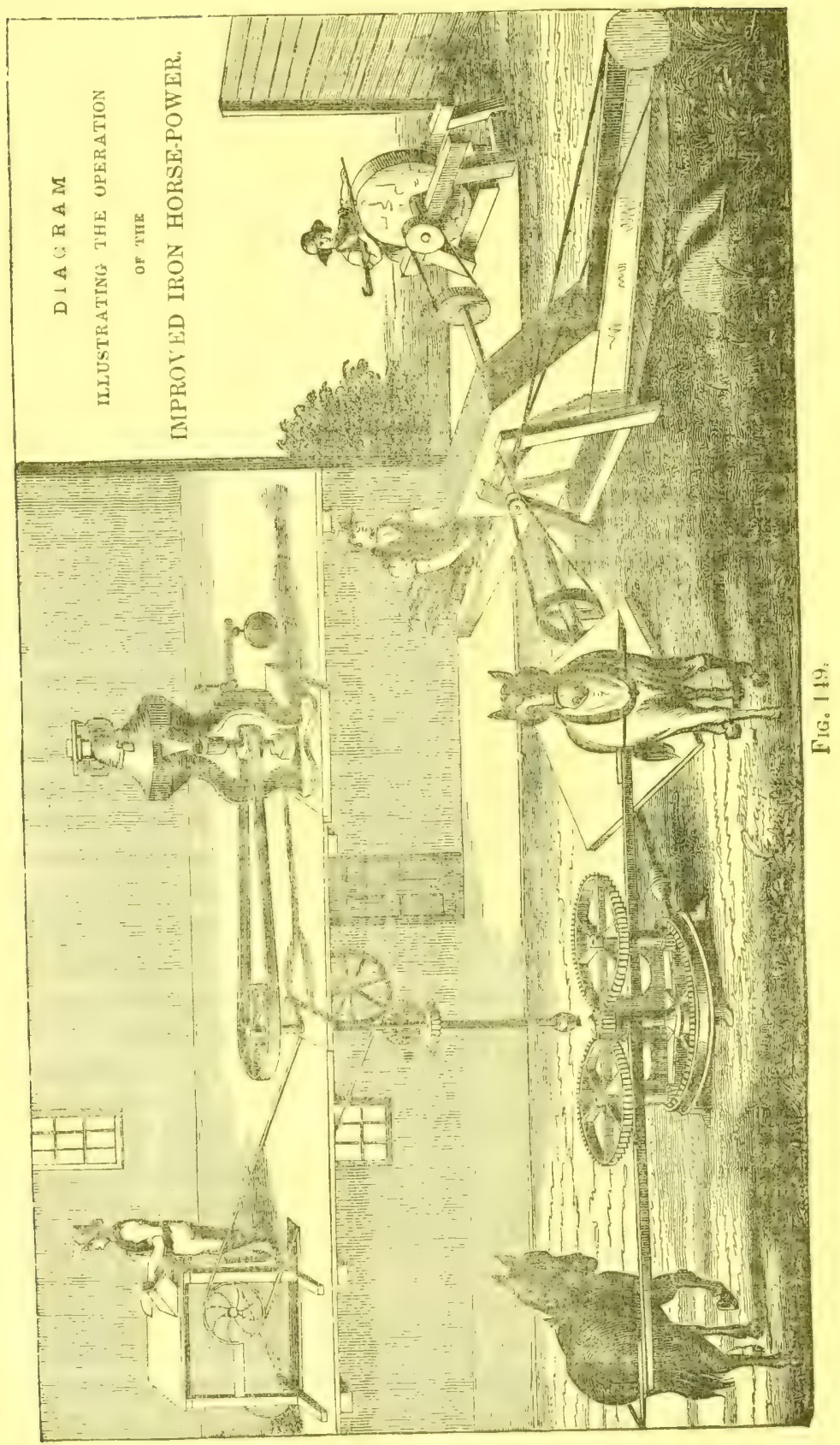


New and Haghy Inproved Iron Horse-Power.

This power is compact, strong, and portable, and without bolts and joints, that are liable to work loose and get out of order. It is made on strictly scientific principles, and is so arranged as to combine the least frietion and greatest durability within the smallest compiss. Five eights of the machine is firmly comnected together, and not weakened by joints, and that on which the power of the horse is exerted, constitutes three eights only; thus throwing the force more directly upon the work to be executed, instead of expending it in overcoming friction, produced by complicated wood and iron frame work and cog wheels. In the gearing, great attention has been paid to prevent friction, by placing two pinions opposite each other and to the centre, thus creating a compensating force around the centre of motion, and at the sume time preventing wear at the journals and bearings.

The horse-power as seen in Fig. I48, will drive the centre upright shatt 28 revolutions to one of the horse; and from this shaft, a strap is taken which drives a corn-mill. On the sime tloor, a corm-sheller is represented in motion, and on the ground floor we have a thresher, separator, and grindstone driven by a shaft geared from the lower end of the upright shaft. 'Ihis shows that a number of applications can be made from the same machine in ore position. If it is required to thresh the grain in the field, it can be done without difficulty, and then replacing the horse-power, as shown in the eut, it can be used tor shelling corn, gimning cotton, pumping water, sawing tirewood, drivmg lutbes, grinding flour, or sawing lumber.

Four-Horse Powers are made on the same principle as the foregoing, and of an additional strength, proportioned to the increased power and striin.

Saw-ifres.-An upright saw-mill driven by a crank is made to be attuched to the foregoing power, which, with two horses only, will saw 100 feet of boards per hour, ont of logs 15 inches diameter or over.

The price of the above sitw-mill and power complete is 8400 for an mill sawing $\log s 13$ feet long. For sawing greater lengths, $\$ 3$ per foot will be charged in addition.

Bormg and Montiswg Machises, - Theso are made to mortise wagonhubs and boxes, plow-beams, sash work, doors, \&e. 


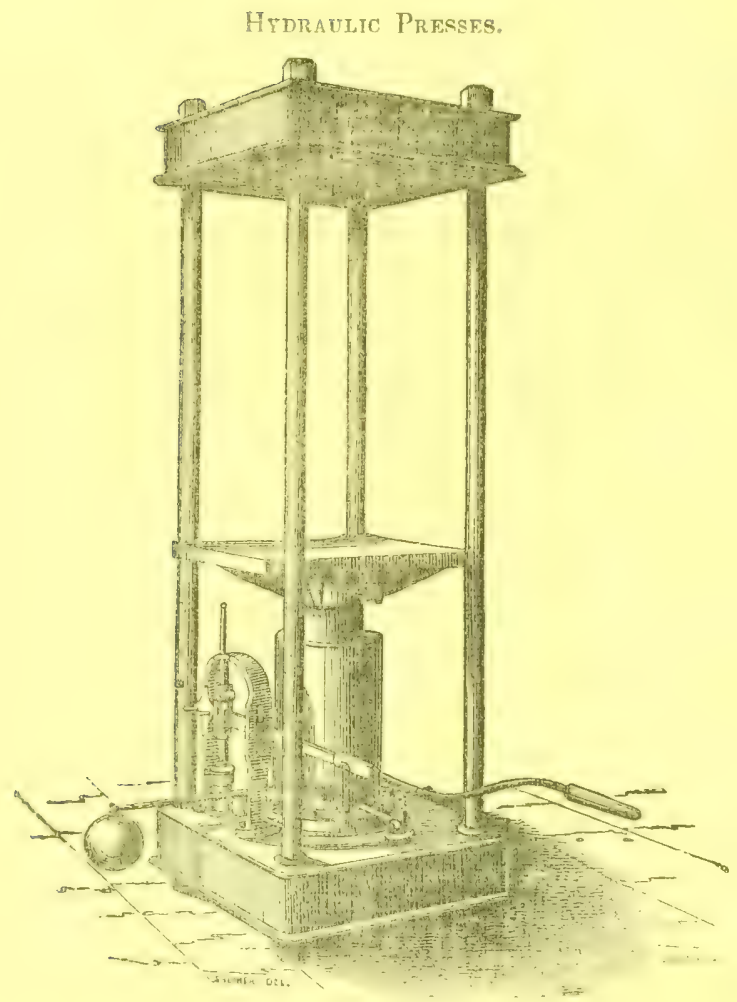

FIg. 150.

These machines are constructed of varions sizes, with solid wrought-iran eylinders, and may be made to work by steam power, with one or more pumps. The uses to which they may be applied are numerous, among which we would particularly mention the pressing of hay, wool, colton bales, separating the oil from lard, flaxseed, castor beans, and other oleaginous seeds. They may also be employed with advantage, in many instances, in raising or moving buildings and other great weights.

Price with 8-inch ram, a single pump, and platine (follower), 38 by 26 inches, $\$ 800 ; 10$-inch ram, pump, and platine 40 by 28 inches, $\$ 1,000$; 12 -inch ram, pump, and platine 46 by 32 inches, $\$ 1,250$. Separate cisterns, sin extra. Larger and smaller sizes made to order.

Post-Hole Augers-These are made of convenient size and length for boring holes in the ground, of dimensions suited to posts of any required sizes. They lift the soil from the hole as it is bored, without the necessity of using shovel, spade, or post spoon. 
GOMTHTI:N CORY-SHEJLER.

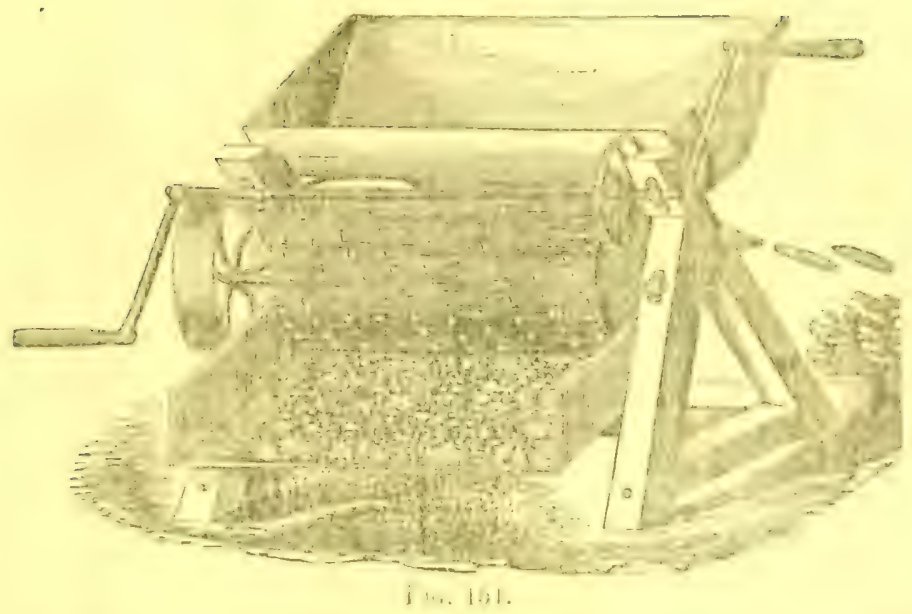

This machine is well alapted for shelling Indian rom. nun is suitable for liurge plintitions. It may be worked by one of two num or by horse power, and sheli by manual liabor about 300 busforls and toy horse power about 700 bushcls per day. It separates the corn firom the cob, both of which are left unbroken.

Endess-Chats Puip

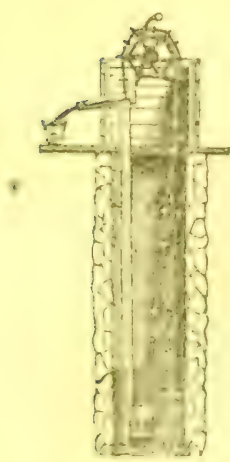

FIG. 152.

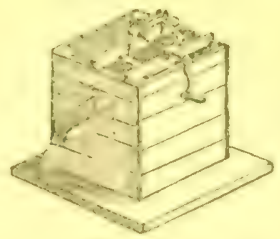

Fig. 153.

This is a very smole pum, which is fast hecoming popular with those whon have tried it. For any depth not excend. inc 25 feet, it worlis admuratb!y; but when the height to which it is required to raike the water is much berond thi: distance, a toreing pumple noty be sulstituted. The grout :idvantages it posserses is cilci of working, simplicity of contstruction, economy of price. and imposibility of freezing in winter.

Maldeatie Cast-Iron Milk Pans,

These are made of various sizes, and lined with porcelain, which prevents the oxydation of the metal by the action of milk or any other liquid which they may contain. 'They combine the strength and duribility of iron, with all the advantages of glass, and ate universally iphproved by ihose who have used them. 
We give below two cuts of the forcing or lifting pump, as it is distinguished from the suction pump. Fig. 155, shows the pump as sold from the warehouse. Fig. 154, as it is placed in the well, the only difference being in the position of the latter which is in the well, with the suction and forcing pipes attached, and the rod, connecting the piston with the handle, lengthened. It will be seen that the force pump is also a suction pump, and capable of drawing water 32 or 33 feet, while its capacity for forcing it upwards in height, is limited only to the strength of the pipes, and the power applied for this purpose.

The force pump has not until

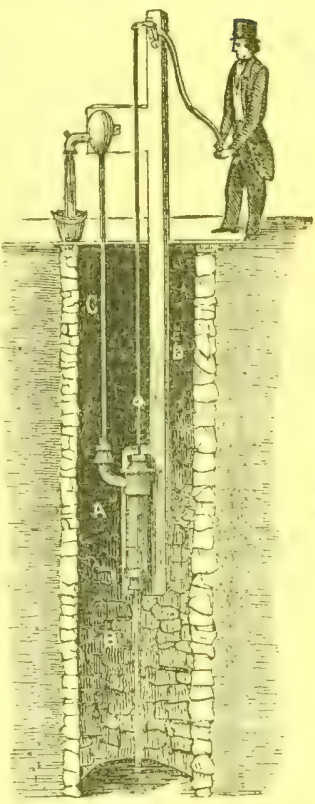

FIG. 154.

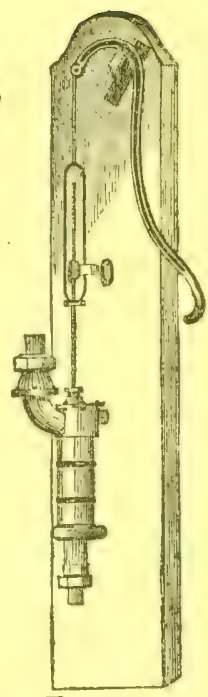

FIG. 155. recently been sold at moderate prices, but late improvements enable the manufacturer to selt them as low as $\$ 12$ or $\$ 15$, for ordinary pumps, and from that up to $\$ 500$, or even more, for the largest and most complete article.

Throstrentstialiy made of about eighten salws, and worked entirely by hand. They gin equally as well as the larger or horse-power gins, but, of course, work much slower.

\section{Hand Cotton Gins.}

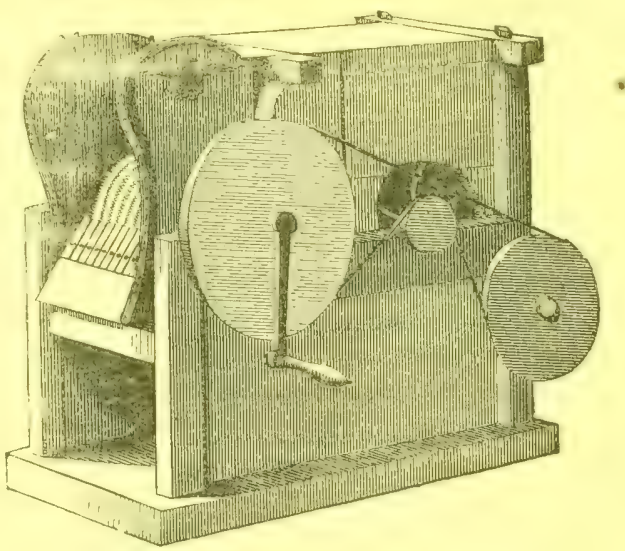

FIG. 156. 
Wond-Sawing Machinf for Cuttreg Fuet.

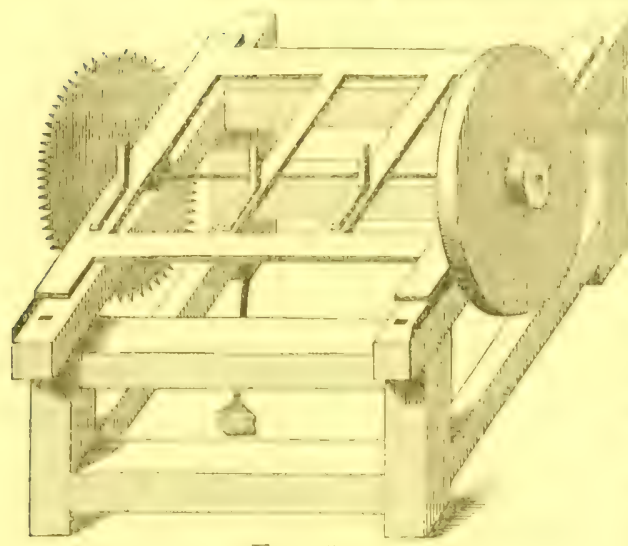

FIg. 157.

'l'ne subjoined cus shows a machine in generul use for sawing wood. It is casily driven by a one-horse chain

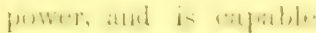
of siwing several cords of woul per lity. It is simple and easily worked and kept in older.

Others, of larger dimensions, are used for slitting plank, boards, scantling, \&c. For this

purpose, a different saw is required than when used for cutting across the grain. For the last purpose, the teeth are triangular; for the former, they are hooked like an eagle's beak. The first is called the cross-cut, the last the rip saw.
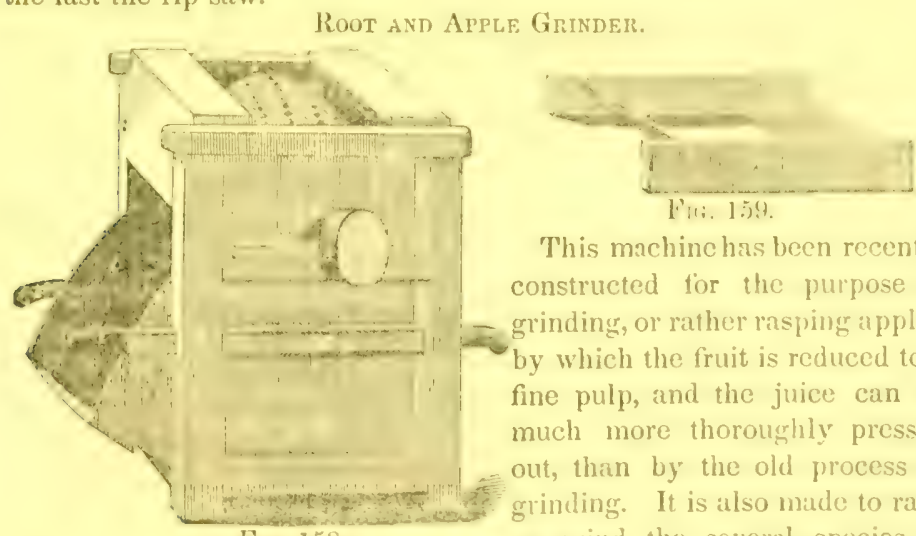

This machine has been recently constructed for the purpose of grinding, or rather rasping apples, by which the fruit is reduced to a fine pulp, and the juice can be much more thoroughly pressed out, than by the old process of grinding. It is also made to rasp FIG. 158 . or grind the several species of roots, as the mandioca, or Brazilian arrow root, the Curcuma angustifolia, or East-India arrow root, the Cycas circinalis, the 'Zamia pumila, of Florida, the Marantia arundinacea, or common arrow root plant of the West Indies, and the yuca or cazabe root, a pliant of Cuba; also potatocs; \&e., from which the arrow root, tapiocar, and starch are made. 'The mitchine can be propelled both by hitnd or horse power, as may be required. Whem large quantities of ruots are to be prepared, the horse power is preterable. We make a smaller machine for rasping horse radish. \&e., which works by treddle power. 


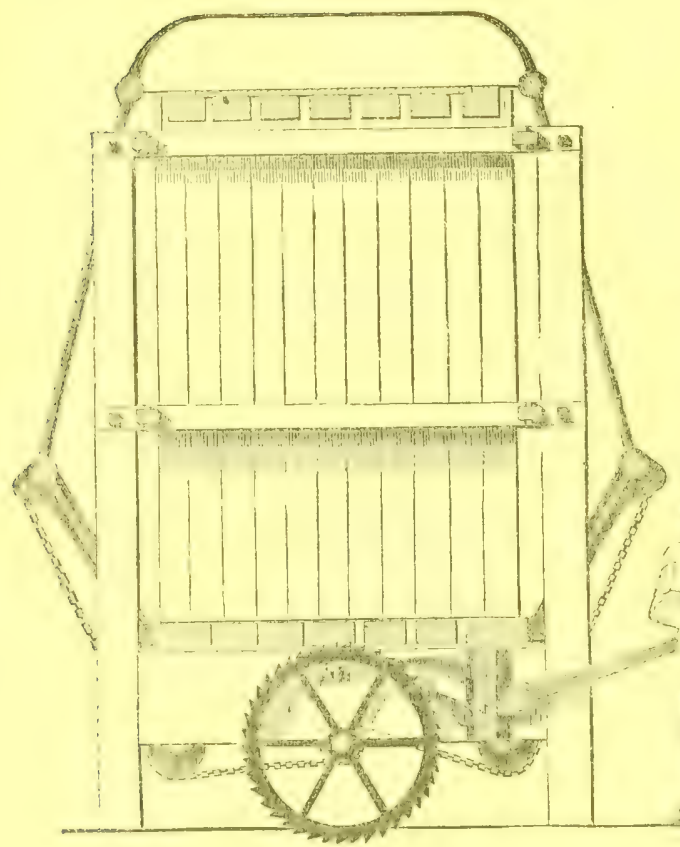

FIG. 160.

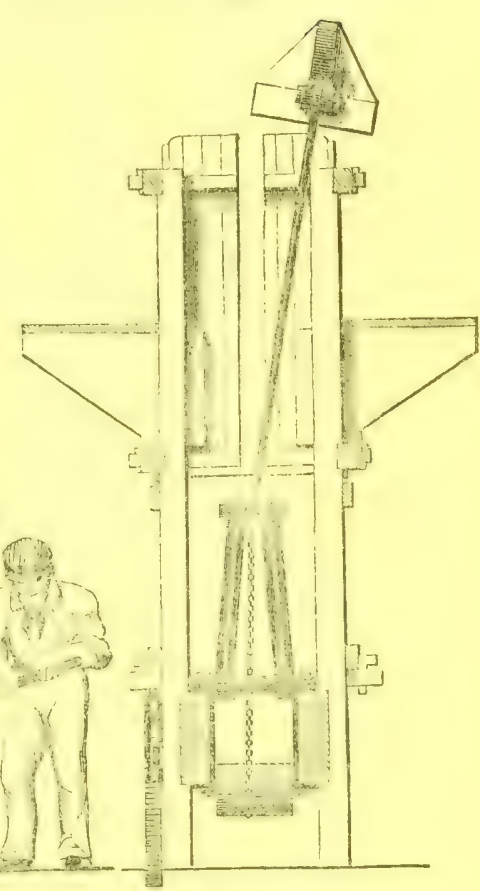

FIG. 161.

F'ig. 160 is a side view of Bullock's Porlable Progressive Power Press. Fig. 161, is an end view of the same, with the follower run up and pushed one side, preparatory to tilling the box.

These presses are in use in this city for baling dry goods, rags, cotton, hay, wool, hemp, flax, paper, moss, \&ce, and they are taking the place of other presses throughout the country. Manufacturing estab. lishments and warehouses, are gencrally adopting these presses on account of their great concenience, power and durability, and the dispatch with which the work is done.

\section{Starch and Arrow-Root Maning Machinfs.}

In addition to those described on the foregoing page, we make others of various forms. Some are made with large cylindrical sheet-steel mrates, that can be kept sharp, and will wear for years, and work very mapirly. Others are made with iron cylinders, and numerous fine stcel saws, that can be taken out, filed, \&c., and re-idjusted at pleasure. Large hoppers are constructed, which have a heavy follower pressing upon the roots, keeping them to the cylinders; and by this means, very much increasing the rapidity of their performance. 


\section{N D E X.}

Animala, domestic descriptuon, PABE. breeding and rearing, \&c., $-79-80$ Apple trees, their cultivation, - - - 77 Artichoke, culture of, Ashes is manure, Anparacus

B.ark-mills.

Beant, culture of Piechives,

Beet, culture of, -

Borecole culturye of

Boilers, veupetable-

Bonealust as manure,

Brick-machines,

Brocesli, enleure of, -

Brusli, or Bramble-hooks,

Brusesels sproute

Bull-rimsen

Bush, or root-pullers,

Cabbarge, culture of,

Carrots

Civlle-tiv-8

Cuttle, Durham, charicter and prices of,

$$
\text { " lierefords, "6 }
$$

" l)evon:

Culery,

Charconal as manure,

Cluever-pressos

Cherry-tlees, how managed,

Chervil,

Churns,

Clovers, cultivation of

Colferemilles

Corn, cultivation of,

" Bronms.

6) planters.

s6 sluellers.

"s and Cutr-crushers,

Itilits

Cotton-wheren cultivators.

Cutton-gins

Cotton-plantery.

Cradles sritin,

Cross, cullivition of.

Cucumberso

Culuwators, warions kimls described.

Cranberry Ralsi,

Emp-plant, cultirntion of .

Endive,

Fire Engine,

Fruning-mills

Fertilisers,

Fruit-rathererd,

Fruit-trees, their cultivation, - $\quad-75-7 !$

Fonntain, water, - - . - 60

Forco Pumps

$166-17$

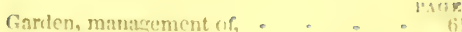

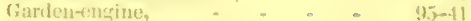

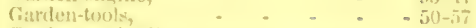

Farden-secls, directions for cultivating, - fid

(iritil-owers, - - - - $-24-25$

firnia-milk - - - $\quad-33-35$

Grat-1:s deseribed, and cultivation of - 69-73

firimel stontus = and cultivation of. - $09-72$

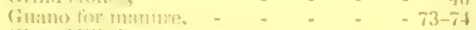

Gliss Milk Pans,

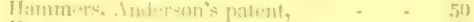

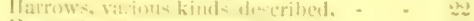

llavrowime, impontituge of, - - = 24

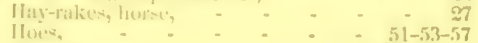

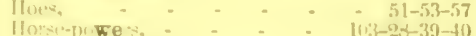

Horses, prices of, - $\quad . \quad$.

Irun chest, fire proof, - - - . 47

knives, prunins ind budting,

lactometer, or cream-trauge - - - 43

(t)

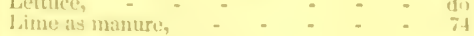

Manures. Sue Furtilisers.

Mamme forlis, -

Melone culdivationot: -

Mowiner meltige

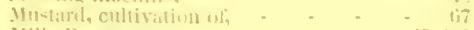

Miale Pans, fir-lui

Xasturtium, how t1:nl, - _ _ _ tii

Okra, how cultivatud, - $\quad$ - _ _ li

Plitning Machine, dr

Parsliy, how cuttivated, - _ _ _ no

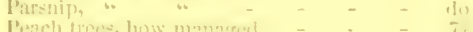

Poar treeso, to

Pow

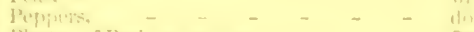

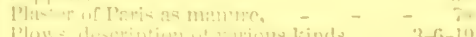

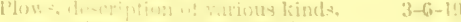

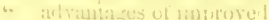

$-2-10$

Tarions peominns awariled to, -

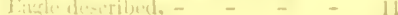

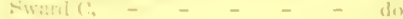

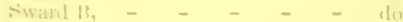

Siwaril1), - - - $\quad-1011-11$

* Seli-horgening, - $\quad-\quad-12-13$

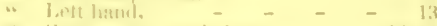

" Liorn, collon, and rice, $\quad$ - $-14-19$

"Ricetrumbine - $-14-19$

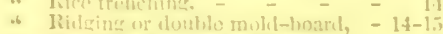

" Flukit for planting stukar-cen: - 13

6 Turt parime, - - - - dr

"6 side-lill, or swivel, - $-\quad-15.18$

60, 6 Subsoil _ _ _ - - - 
INDEX.

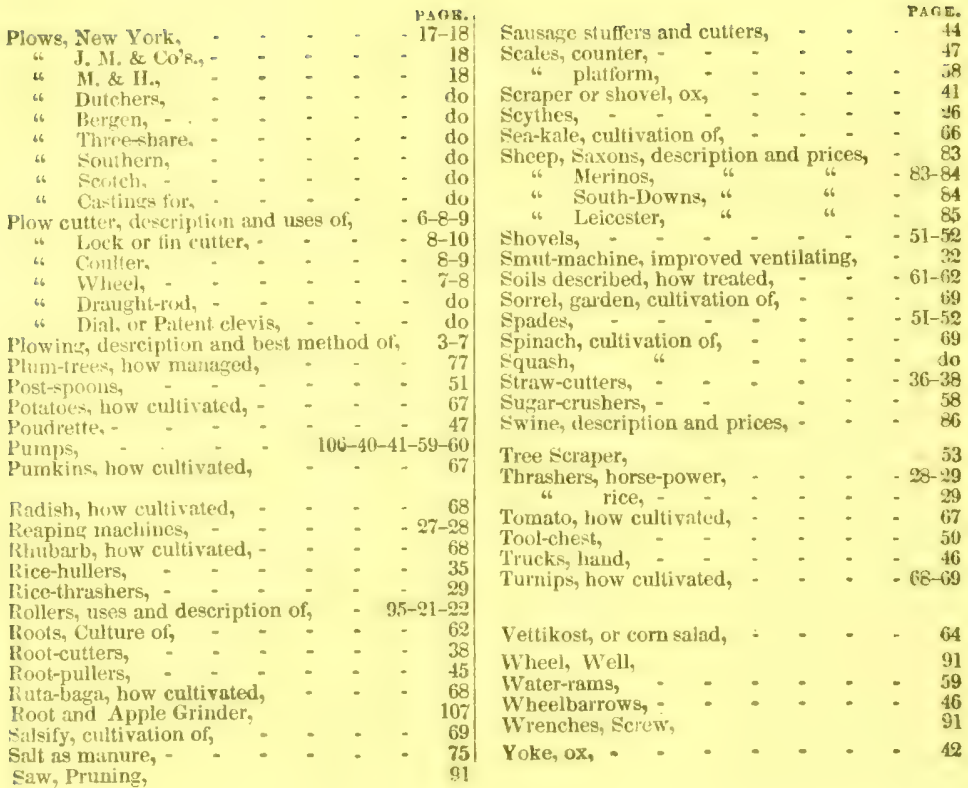

\section{A P P ENDIX.}

Blacksmith's forge and Bellows,

Foring and morticing machine,

Bullock's progressive power preses,

California Tools,

Canal and Railroad barrows,

colding ladders,

fiurden-Chair, Cast-Iron, -

siarden syringes,

bydraulic presses,

indeetructible Mineral Paint.

\begin{tabular}{|c|c|c|c|c|c|}
\hline 96 & Itont Wire cloth, Sie & es, Fer & 1.0 & ec, & 95 \\
\hline 98 & latrice liorse carts, & $-\quad-$ & - & - & 83 \\
\hline 103 & Omnibtres, Railroad & Cars, & & $=$ & - \\
\hline 89 & Planing Niachme, & - & - & - & - \\
\hline & Simus itachine, Pilli & iton's, & - & - & $\cdot$ \\
\hline 93 & Steam-engines, - & - $\quad-$ & - & - & - \\
\hline & Surar-Mill, - & - & . & - & - \\
\hline 8 & Truck wagons, - & - & - & - & - \\
\hline 97 & Two-horse wagons, & 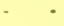 & - & - & \\
\hline & Saw-mills, - & - & . & $\cdot$ & 107 . \\
\hline & Wire for fenees, & - & - & - & - \\
\hline
\end{tabular}




\title{
A M E R I C A N A R C I I T E C T,
}

\section{omplete in 24 Nos.. at 25 cents each, or $\$ 5$ for 21 Nos. $\$ 6$, bound in 2 rols.}

\author{
PUBLISHED BY C. M. SAXTON, NEW-YORK.
}

THE object of this publication is to introduce ORIG!NAL DESIGNS of Comatry Seats adapted to the varied taste and circumstances of an American population from the elegant VILLA to the simple CoTTAOE and plain FARM-HOUSE: from PLANTERg' ilansions to Villag Domicils. In a word, every variety of RURAL RESIDENCES will be emb:aced, in order to meet the views of every person desirng RESIDENCES WHO E. In respect to style, cost, arrangement, finish, \&c., utility will never be sucrificed: commy in the onliay, with an appropriate style, wil always be kept in view. The requisite details, specifications, plans, and direc tions, with a careful and reliable estimate of the cost, will accompany each design These are essential features of a Practical Work, and no labor will be spared in their preparation.

Of the diversity of human dwellings, whether marked by elegance, convenience, or utility, or by the want of thela, none ent compare in matimal importance and philosophical interest with the Farm-House-the Hornestead of our species.

A triple value attaches to that class of men which feeds all others. IVith primeval farmers, man's social faculties were first unfolded. With them society began: and among whatever people its shaft has become polished and its capital enriched, it still rests on the chltiv ators of the soil. Sn. nf their profeceion, aericuiture is the great parent of the arts, while its prepared products will forever cuture is the essential of all manufactures. Then it was in their dwellings that ve the most essential of its birth; it was they who first abandoned the tent with Architecture itself had its birth; it was they who first abandoned the tent

The estimates we give are based on New York prices; including the best maerials, workmunship, and finish. There is no doubt that in many parts of the country, they may be materially diminished in every one of these respects-evee to the extent of one-half.

to the extent of one-half. nonly attended with embarrassment and always with expense when furnished non mofessional men, from general ideas communicated by proprietors, they are seldom satisfactory. The American Architect, by furnishing a collection of desigms beldom satisfactory. The Ameans, will remove every difficulty in the choice, and adapted to all tastes and means, will remove every diftenty in the choice, and Plans, and Specifications in each year, at a price not exceeding one-seventh of the usual charge for one.

Every handsome residence adds value to the grounds attached to it, hence the Every handsome resich, by those who invest capital in this species of property. importance of having such, by those wh distribution of the apartments and the ataptation to the purposes intended is the most important point to be attended 20, and they are governed by the Plans.

From among the great number of notices, we select the foilowing :-

"The price is only 25 cents for each number, and it is surely next to impossible but that such a perodical will obtain a wide circulation."-Ncro York Tribune.

"This work promises to supply a want which has long existed, and to be of essential value." - Salem Register.

"This work cannot fail to be useful and popular."-b.ston Bee.

"This is a good and beantiful work, and well ndapted to effect a mucli desired reform in American Architecture." - Boston Traveller.

Th, Cost of building from the Plans given, will be from $\$ 600$ to $\$ 5,000$, wits comp gte Specifications from a first-rate Mason and ('appenter, and the proce ziren an loe depender' upon. 


\section{THE AMERICAN FARM BOOK:}

OR,

\section{Compend of American Agriculture,}

Sortaining a concise a d lainly written Exposition of Duties pertaining to the Cultivation of the Earth, th. Management of the Farm, \&c.. \&c., on prac. tical scientific princivles.

BY R. L. ALLEN.

Tho chapest and most valuable bnok for a farmer aver printed : being a cor plete Guide, both practical and scientific, for the

\section{MANAGEMENT OF THE FARM.}

Besudes the varied practical knowledge which this book imparts, and which is unispensable to the proper management of every department of agriculture, it rives the elements of other information highly necessary to a successful farmer ss History, Geology, Clemistry, Dutany, Anatoray, Physiology, and Mechanics These hranches of knowleage are given as applicable to agricultural pursuits and when properly unlerstood will essentially aid and assist the farmer. In fact a knowedge of tliese sciences is a sure key to wealth for any agriculturist. I tives the mode of Jrevaracion, and the: effects of all kinds of manures : the origin, texture, divicions. and description of every variety of soils; the economy af sowing. reaping. and nowing. irrigation and draining; cultivation of the prasses, clovers grains, and irouts; Southern and miscellaneous products, as cot. fon, heim, fiex. the surar cane, rice tobacco, hops, madiler, woad, \&c. : the rearing of fruit-apples, weachns, pears. plums, grapes, \&c ; farm buildings sedges. Scc.; with the bent methols of planting, cultivating, and preparatiou for market. Illustrated by l(it) engravinge.

The reader can form some ilea if the abuve work, from the fact that it treats

s 800 different subjects important to a farmer. It contains 354 pages, and beautifully bound in cloth, gilt, suitable for a library. Price only One Dollar.

Notices of the Press.

The author has been one of the most able contributors to the agricultural pres ur the last ten years ; aside from this he is a practical farmer and stock-breeder and consequently knows from his own experience what he is writing about. Commercial Advertiser.

Thus book is by a gentleman of known experience; the worls is exceedingly jeap, and the farmer will find it a valuable book of reference. $-N$. Y. Express.

It is in fact a brief encyclopedia on the subjects treated, and the farmer will 7.1.? approprate information on almost any subject coming within his reach.vin York obscruer.

Ileri is a book for the million, preciseiy what its title indicates. Compassed whthm its pages, the reader will fund the subject of soils, manures, crops, and mumals, treated in a style easily comprehended.-Spirit of the Times.

Tinis work is what might be expected from one so well qualified for the underLitiking.-Bioston Cultivalor.

bi fure glial to meet a publication which can interest, as well as improve the iomlition of the human race. We commend the work to every American farmer. - Christian Intelligencer.

iv'ly silati not every good lammer economize his muscles by storing his mind? ite hupe this book will find its way mo many family and school-libraries.-New Virk Iribune.

It whaht to be found in every farmer's library.-Jerseyman.

ft ls really a great satisfaction to get hold of au American treatise on Agricul.

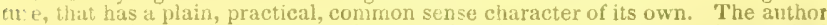
of i his work is alrendy lnown to the agricultural public as a thorough practical firmer anit stock-breeder. 'That he well knows what he is about on a farm, these p.wes abundanty sliow. No mere book-maker could have written such a book; anit we may adu, also, that no mere pactical farmer could bave writen it. A "good practical work" can only be written wy a man who has buth thought and ac ed well. What distingulshes this volmme, is its conciseness, its clearness, and ts jerspicuous treatment of the subject in land. We think, therefore, that Mr Alien's volunse, the basis of which is goed pratetical farming, as practised by th best cultuvitors in the Inted Stites, with an intelligent reference to those princ ples of science wbich he at the root of all successful practice, is likely to be of as guch or more real service to us, thin any work on igriculture vet issued srom the press, and we gladly conmend it to he perusal of every on of our reader

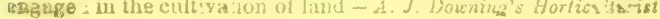




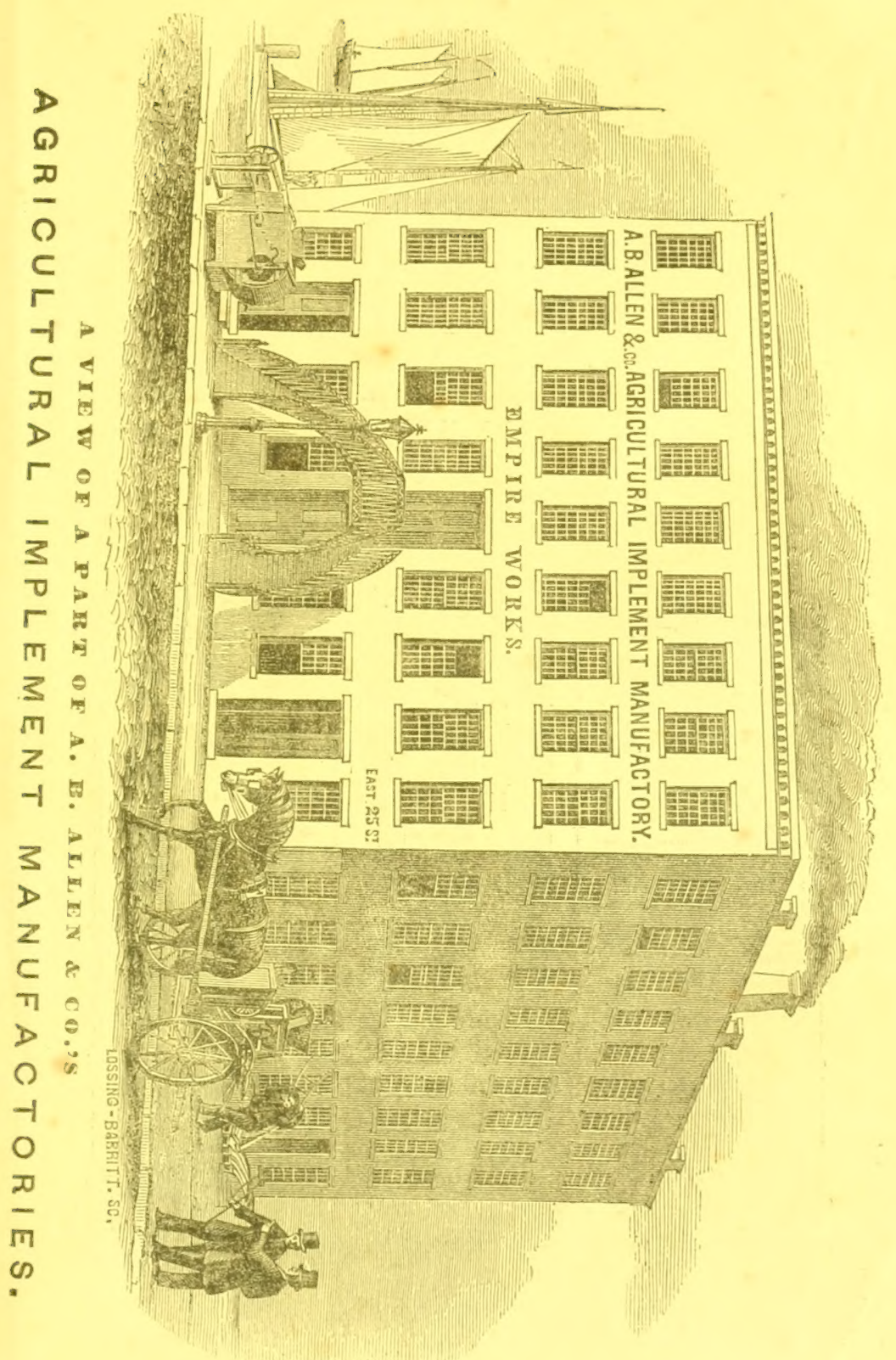


LIBRARY OF CONGRESS
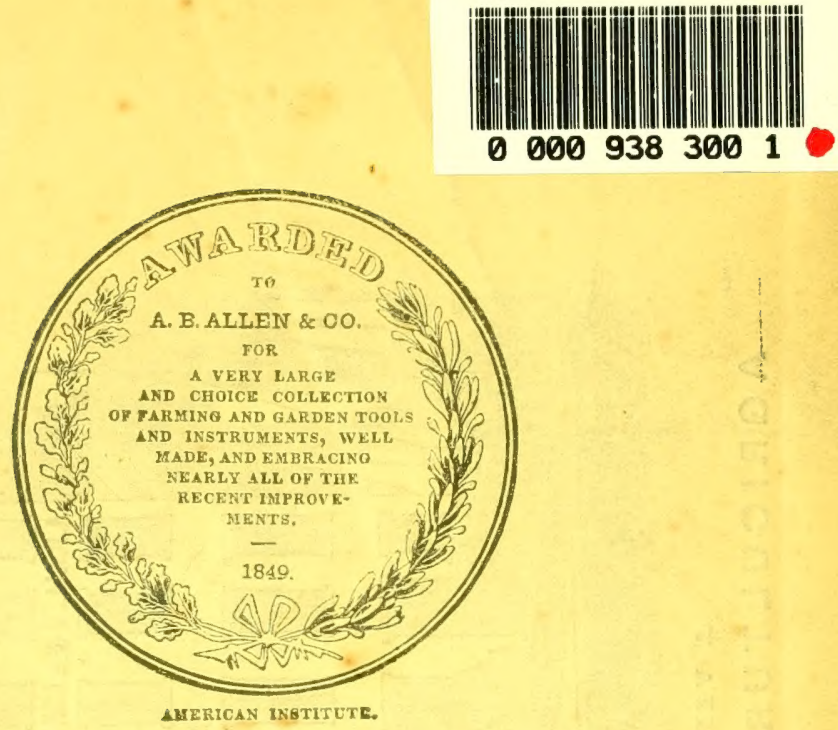

G OID MEDAL.

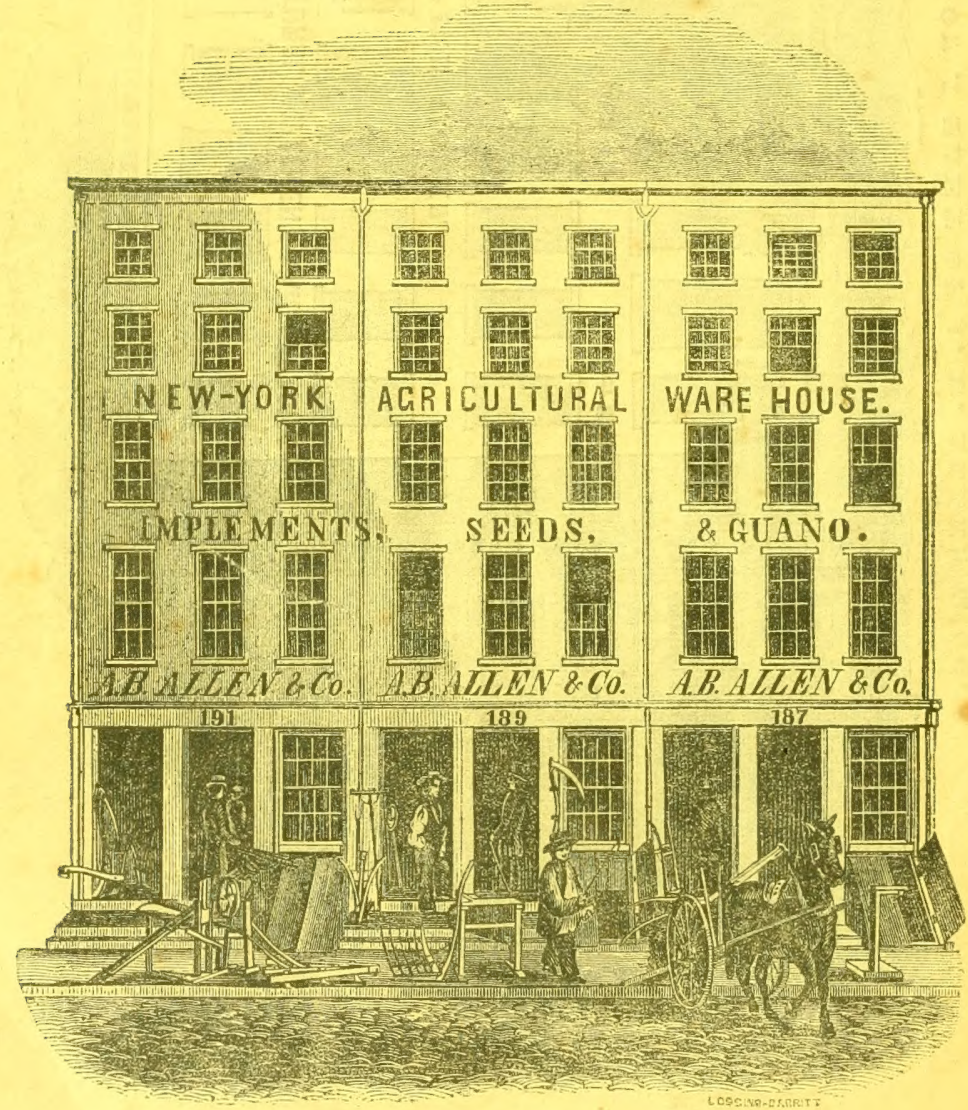


. A42 
LIBRARY OF CONGRESS

||||| || || || || || || || ||||||||||||||||||||||

00009383001

Hollinger Corp. pH 8.5 